\title{
Mortality of marine mussels Mytilus edulis and M. galloprovincialis: systematic literature review of risk factors and recommendations for future research
}

\author{
Lupo Coralie 1, 2, ${ }^{*}$, Bougeard Stéphanie ${ }^{1}$, Le Bihan Véronique ${ }^{3}$, Blin Jean Louis ${ }^{4}$, Allain Gwenhael ${ }^{5}$, \\ Azéma Patrick ${ }^{6}$, Benoit Fabienne ${ }^{7}$, Béchemin Christian ${ }^{2}$, Bernard Ismaël ${ }^{8}$, Blachier Philippe ${ }^{9}$, \\ Brieau Léa ${ }^{10}$, Danion Morgane ${ }^{1}$, Garcia Aurélie ${ }^{10}$, Gervasoni Erika ${ }^{11}$, Glize Philippe ${ }^{12}$, \\ Lainé Audrey ${ }^{13}$, Lapègue Sylvie ${ }^{2,14}$, Mablouké Cécile ${ }^{11}$, Poirier Laurence ${ }^{15}$, \\ Raymond Jean Christophe ${ }^{16}$, Treilles Michael ${ }^{7}$, Chauvin Claire ${ }^{1}$, Le Bouquin Sophie ${ }^{1}$
}

\footnotetext{
${ }^{1}$ Anses Laboratoire de Ploufragan-Plouzané-Niort Ploufragan, France

${ }^{2}$ Laboratoire de Génétique et Pathologie des Mollusques Marins (SG2M-LGPMM) IFREMER La Tremblade ,France

${ }^{3}$ Laboratoire d'Economie et de Management de Nantes Atlantique (IAE Economie et Management)

Université de Nantes Nantes, France

${ }^{4}$ Synergie Mer et Littoral Blainville-sur-mer ,France

${ }^{5}$ Armeria Lorient, France

${ }^{6}$ Direction Générale de l'Alimentation, Bureau de la Santé Animale Paris,France

${ }^{7}$ Association Française des Directeurs et Cadres de Laboratoires Vétérinaires Publics d'Analyses

Paris ,France

${ }^{8}$ Eurêka Modélisation Morlai, France

${ }^{9}$ Centre Régional d'Expérimentation et d'Application Aquacole Le Château d'Oléron ,France

${ }^{10}$ Groupe d'étude des milieux estuariens et littoraux-Normandie Luc-sur-mer ,France

${ }^{11}$ Centre d'étude pour la promotion des activités lagunaires et maritimes Sète, France

$1^{2}$ Syndicat Mixte pour le Développement de l'Aquaculture et de la Pêche en Pays de la Loire

Nantes ,France

${ }^{13}$ Comité National de la Conchyliculture Paris,France

${ }^{14}$ MARBEC IFREMER CNRS IRD Univ Montpellier Montpellier, France

15 Laboratoire Mer, Molécules, Santé (MMS) Université de Nantes Nantes, France

${ }^{16}$ Comité National des Pêches Maritimes et des Elevages Marins Paris ,France

*Corresponding author : Coralie Lupo, email address : clupo@ifremer.fr
}

\begin{abstract}
:
The aim of this study was to summarise the literature reporting the risk factors for mortality in the mussel species Mytilus edulis and Mytilus galloprovincialis in order to identify potential science-based solutions to prevent or mitigate mussel mortality outbreaks. We followed the PRISMA methodology: Preferred Reporting Items for Systematic Reviews and Meta-Analyses. The studied corpus of 91 publications (114 studies) was highly heterogeneous with respect to the methodological approaches used to define or estimate mussel mortality and the related putative risk factors. Results showed that the mortality risk of both mussel species $M$. edulis and $M$. galloprovincialis varied across the seasons, increased with an elevated seawater temperature above a thermal threshold of 20 and $24^{\circ} \mathrm{C}$, respectively, decreased by
\end{abstract}


protecting mussels from predation, and was associated with the presence of pathogens in M. edulis. For M. galloprovincialis, using mussel spat from the same area where the farming is carried out and farming them together with another mussel species appears to reduce the mortality risk. However, for M. edulis, this could be achieved by using pure crosses and in particular mussel spat having a selected genotype. For wild bed conservation, sand accumulation and anthropogenic sedimentation should be minimised. Our analysis showed that current approaches to this research topic are limited and are unlikely to yield actionable evidence to identify mussel mortality prevention or mitigation strategies. Therefore, recommendations are offered to increase the ability of future eco-epidemiological research to identify multiple exposures associated with mussel mortality, underpinned by standardised efforts and cooperative initiatives.

Keywords : eco-epidemiology, environment, husbandry practices, mussel health, pathogens 


\section{Introduction}

Over the last decade, massive mortalities have been reported on a recurrent basis in different marine bivalve species along the French coastline: spat of the Pacific oyster (Crassostrea gigas) (Miossec et al., 2009), wedge clam (Donax trunculus) (Garcia et al., 2018), marketable-size Pacific oysters (Garcia et al., 2014), cockles (Cerastoderma edule) (Garcia et al., 2019), and mussels (Mytilus sp.) (Garcia et al., 2015 ; Lupo \& Prou, 2016). The aetiology of these mortalities is often unknown and the current consensus within the scientific community is that their origins are multifactorial. These mass mortalities may reflect a marine disturbance, and thus, damaged health of the marine coastal ecosystem (Sherman, 2000). Additionally, these recurrent mortalities cause an imbalance in the entire coastal socioecosystem, and stakeholders need to adapt permanently to ensure the sustainability of their socio-economic activities (Guillotreau et al., 2017). Representative bodies of the shellfish industry often alert the government authorities about these sustainability concerns, asking either for research to be conducted to explain these mass mortality events and to mitigate the outbreaks, or for financial compensation to mitigate their effects on socio-economic activities. For example, during the massive mortality events that occurred in mussels along the Atlantic coastline of France in 2014, several regional-scale studies were rapidly launched by various research groups (Bernard \& Allain, 2016 ; SMIDAP, 2016 ; Travers et al., 2016).

After almost a decade of research on shellfish mortalities, the French Ministry in charge of Agriculture decided to coordinate research efforts at the national level by establishing a research programme, and in 2016 set up a national expert panel (called the Scientific and Technical Council, STC) to supervise this project, which consisted of the co-authors of this manuscript. The STC panel brought together all the scientific and technical bodies and institutions in France that have expertise in key related areas, including laboratory diagnostic 
analyses, shellfish farming and fishery practices, the chemistry of coastal and marine environments, economics, ecotoxicology, epidemiology, genetics, hydrodynamic modelling, shellfish pathology, shellfish physiology, and ecosystem quality. The formulated objective of the research programme was "to understand the interactions between the physicochemical conditions (abiotic factors) and the biotic factors in the environment, and the infectious status, as well as the impact of these interactions on the mortalities of the farmed and wild shellfish. [...] The programme should explore how contaminants from the terrestrial and marine environments, currents and sediment fluxes, and physicochemical changes in seawater, contribute, as a function of the presence of pathogens, to influence the level of survival of Pacific oysters, mussels and other shellfish species affected by unexplained massive mortality events, at different physiological stages, and taking into account farming or fishing practices and genetics, if necessary" (Anon, 2016). The first step was to review the knowledge related to the risk factors for shellfish mortalities in order to identify potential solutions to limit the impact of mortality events. If required, a second step would be to conduct a large eco-epidemiological study at the national level. As massive mortalities in marine mussels were reported at that time (Garcia et al., 2015 ; Lupo \& Prou, 2016), the STC chose to carry out a literature review on these species. The STC panel started its activities in November 2016 and submitted its final report in January 2019.

The objective of this study was to summarise the current literature reporting the risk factors for mortality in the mussel species exploited in France, Mytilus edulis and Mytilus galloprovincialis, in order to identify potential solutions to prevent or mitigate mussel mortality outbreaks, using the systematic review methodology. A systematic review is an overview of existing evidence relevant to a clearly formulated and specific question, which uses pre-specified standardised methods to identify and critically appraise relevant research, 
and to collect, report and analyse data from the studies that are included in the review (Moher et al., 2009). Methodological rigour, transparency and reproducibility are the fundamental principles underyling a systematic review. This method follows a series of steps to reduce bias in the selection and inclusion of the studies that address the review question, and to objectively summarise the quantity and the quality of evidence. Systematic reviews can be helpful when there is a large amount of evidence because they can guide funding decisions for future research and reduce unnecessary duplication of research. If the evidence is scarce, systematic reviews can be particularly helpful to formally identify knowledge gaps and to identify evidence not previously known to exist. If the research findings identified are of poor quality, then this method will document the limitations and weaknesses of the existing evidence and make informed proposals for the design of future research (European Food Safety Agency, 2010). Thus, as part of the review process, this study also aimed to identify gaps in knowledge on mussel mortality risk factors, and to formulate recommendations to help target future research. 


\section{Methods}

\subsection{Scope of the study and research question}

This review was conducted following a protocol developed a priori to minimise the subjective decisions that could be made during the review process, and was reported according to the Preferred Reporting Items for Systematic Reviews and Meta-Analyses (PRISMA) guidelines (Moher et al., 2009).

Based on the terms of reference formulated by the French Ministry in charge of Agriculture (Anon, 2016), this review covers risk factors for marine mussel mortalities, with the following question: "What are the risk factors for mussel mortality included in the topics of animal characteristics, farming or fishery practices, seawater characteristics, contaminants from the terrestrial and marine environments, pathogens, climate characteristics, and geographic characteristics of the farming/fishing site?". Thus, the specific research question was defined including the key elements for review of risk factors, using the PECO format:

- Population of interest $(P)$ : mussel species exploited for human consumption in France, i.e. Mytilus edulis and M. galloprovincialis;

- Exposure (E): any exposure to factors pertaining to the following seven topics: animal characteristics, farming or fishery practices, seawater characteristics, contaminants from the terrestrial and marine environments, pathogens, climate characteristics, and geographic characteristics of the farming/fishing site;

- Comparator $(C)$ : only explanatory studies employing some form of comparison or control group against which the exposure can be compared, were included;

- Outcome of interest $(O)$ : mortality.

\subsection{Literature search strategy}


An exhaustive literature search, including electronic and manual searching, was performed. To ensure completeness of the search, key PECO elements were combined in a search algorithm using Boolean operators. Search equations were adapted to the different databases explored (Appendix I).

Searches were carried out in the following online bibliographic databases: Web of Science, Scopus, Aquatic Sciences and Fisheries Abstracts, CAS Abstracts, Pascal and Francis, and Environmental Sciences and Pollution Management, on 03 May 2017; the search was updated on 05 April 2018, and 13 November 2018. Manual searches were also performed in available online databases and proceedings of the following conferences: Society for Veterinary Epidemiology and Preventive Medicine (SVEPM), International Symposia on Veterinary Epidemiology and Economics (ISVEE), National Shellfisheries Association (NSA), World Aquaculture Society (WAS), European Aquaculture Society (EAS), European Association of Fish Pathologists (EAFP), Annual meeting of the European Union Reference Laboratories for mollusc diseases, International Symposium on the Advances in Marine Mussel Research (AMMR), Annual council of the French Shellfish Industry, and Annual Ifremer meeting of Surveillance and Reference for mollusc diseases. To identify grey literature (i.e. unpublished studies) focused on risk factors for mussel mortalities, regional and national representative bodies for shellfish farmers and those for fishermen, regional technical institutes, and private consulting engineers were contacted and data were requested in February 2017; the search was updated in November 2018. These bodies belonged to the SCT panel or to their networks. Manual searching of the reference lists in all of the citations that met the eligibility criteria (see below) was conducted as the review progressed.

A unique code was attributed to each captured citation. Citations captured by the search on the online bibliographic databases were saved in ris format. All the identified citations were 
gathered in a single electronic database. Duplicate citations were removed by electronic and manual scanning. The final unit of this work was no longer the citation but the study, identified by a unique study code derived from the citation code.

\subsection{Study selection: inclusion and exclusion criteria}

Inclusion and exclusion criteria were built using the key PECO elements. Both laboratory and observational studies were included. The following additional exclusion criteria were applied: citations published in languages other than English or French, or before 2006 (to account for progress in the techniques used for pathogen or chemical detection), or concerning mussel larvae (i.e. before their fixation on a collector), or concerning human foodborne pathogens (e.g. Vibrio parahaemolyticus), or purely descriptive or case report studies. Only original research studies were included; review articles were excluded.

\subsection{Review process}

The purpose of relevance screening in the systematic review methodology is to rapidly remove citations not relevant to the review, as the literature search process should be highly sensitive, with low specificity. This first step was based on title and abstract screening of the identified citations. Citations excluded at this stage were not assessed further. The study selection was conducted unmasked, i.e. the reviewers had access to the authors' names. Screening of the whole corpus was conducted by a single reviewer, with a second independently examining the first reviewer's work for a random sample of the identified citations, with 30 citations per member of the STC $(\mathrm{N}=13)$. The second step was based on the full text examination of the citation. Citations excluded at this stage were documented for the reason behind their exclusion in a dedicated table (Appendix II). The full text screening 
was conducted by a single reviewer, with a second validating the first reviewer's work for two citations per member of the STC $(\mathrm{N}=11)$.

When disagreements on study selection occurred, the reviewers discussed and sought consensus. At each step, the kappa coefficient was calculated to evaluate the agreement between the inclusion/exclusion decisions of the first reviewer and the STC, using the interpretation of (Landis \& Koch, 1977), where values <0 indicate no agreement, values 00.20 slight, 0.21-0.40 fair, 0.41-0.60 moderate, 0.61-80.80 substantial, and 0.81-1 almost perfect agreement.

\subsection{Study methodological quality and field transposition assessment}

For each included study, we built a quality score based on key features of the study design, to assess the appropriateness of the methodological aspects to identify a risk factor. Three levels (low, moderate or high) were assigned to this methodological quality score, based on a combination of key study design features for observational and experimental studies. For observational studies, criteria were the random selection of epidemiological units and the strength of proof of causal association provided by the study design. A moderate strength of proof was attributed to transversal and single cohort studies, whereas a high strength of proof was attributed to exposed/non-exposed cohort and case-control studies. For experimental studies, criteria were the use of a control during the experiment or a design of experiments (when several risk factors were investigated), and the number of replicates of the experiment. At least three replicates were considered as strength to assess the variations in experiment outcomes. 
For laboratory studies, an additional criterion was built to evaluate the relevance of the results to "real-world" conditions. Two levels (low or satisfactory) were assigned to this field transposition score, based on the environmental relevance of the physical parameters of the seawater and of the tested chemical concentrations, and the route of exposure to the pathogens, and by excluding intramuscular injection that forced the natural barriers of the mussels. To assess the environmental relevance of the physical parameters of the seawater, we used the ocean monitoring indicators collected by the EU Copernicus Marine Service Information (EU Copernicus Marine Service Information, 2019) for the 1993-2017 period for seawater temperature and salinity, and 2001-2016 period for seawater $\mathrm{pH}$. To assess the environmental relevance of the chemical concentrations, we used the chronic predicted noeffect concentration (PNEC) in marine waters, which is the concentration of a substance in any environment below which adverse effects will most likely not occur during long-term exposure (INERIS, 2019). Results of studies using chemical concentrations greater than 250 times the PNEC were considered as not relevant to the "real-world" conditions, except when the studies mimicked a field pollution event. In addition, studies using the stress on stress (SOS) test, i.e. survival in air test, to identify the negative effects of chemicals were excluded.

Scoring for methodological quality and field transposition assessment was conducted by one reviewer. The studies with low quality scores or low field transposition scores were excluded from the review (Appendix II).

\subsection{Data extraction from the included studies}

Data were extracted and collated in a Microsoft ${ }^{\odot}$ Excel spreadsheet. Two templates, for either laboratory or observational studies, were developed a priori to standardise the extraction of information from the selected studies as far as possible. The unit was no longer the citation 
but the study. The templates were further reviewed and enriched by all co-authors and pilot tested before use. Some fields were standardised, using drop-down lists, and others were left open because the related information was considered difficult to predict. Table 1 lists all extracted data, if available, from the selected corpus.

For each putative risk factor, the effect of exposure on mussel mortality risk was extracted and categorized as increasing, decreasing or no effect. Absence of effect referred to comparisons between controls and treatment/cases that were statistically non-different. Seven topics concerning mortality risk factors were defined based on a consensus among the STC members: pathogens, mussel characteristics, seawater characteristics, characteristics of the farming or fishing site, farming or harvesting practices, pollutants from the terrestrial and marine environments, and climate characteristics.

Data extraction was conducted by a single reviewer and was checked by a second reviewer for two citations per member of the STC.

\subsection{Data analyses}

Summary distributions of extracted characteristics were examined by mussel species and study conditions (i.e. observational or experimental). A qualitative analysis of open fields was conducted a posteriori, to build categorical variables having different response modalities. Each categorical variable was then described in terms of numbers and frequency of its modalities. These were used to write a narrative synthesis of the results, summarising information on the characteristics of the included studies, such as study conditions and design, and the outcome and exposure effect measures used. 
Multiple correspondence analysis (MCA) was used to identify groups of studies with similar profiles regarding the extracted characteristics (i.e. categorical variables) and the associations between studies and characteristics (Greenacre, 1984). This method is used to detect and represent underlying structures in a dataset, by representing data as points in a lowdimensional Euclidean space. It produces graphs on which the studies are represented by points which tend to group together if the studies are similar; differences, on the contrary, tend to produce distance. Fourteen active variables were used for the MCA: year of publication, mussel species, study conditions, geographical location, mussel population type, quality score, the seven themes of mortality risk factors, and interaction considerations between risk factors. When the frequency of studies in a variable category was $<10 \%$, this category was grouped with another category, if relevant. The contributions of the variables to each factorial axis and the plots of the MCA were used to interpret each factorial axis.

The descriptive analysis was conducted by using $\mathrm{R}$ software, version 3.6.1 (R Core Team, 2019). Study screening based on the title and abstract was conducted using the Metagear package (Lajeunesse, 2016). MCA was carried out using the FactoMineR (Lê et al., 2008) and Factoextra (Kassambra \& Mundt, 2017) packages. Plots were built using the ggplot2 package (Wickham, 2016). 


\section{Results}

\subsection{Literature search and selection}

The initial search identified 5,450 citations in the electronic databases, and through manual searching in the conferences and referrals from the SCT, published between 2006 and 2018. After removal of duplicates, 3,715 remained for further screening. Screening the titles and abstracts excluded another 3,526 citations, leaving 189 citations for a full text review. Subsequently, an additional 92 citations were excluded. We included 19 articles by scanning the reference lists of included citations. These 116 citations contained reports on 152 studies that were critically appraised individually. Assessment of the methodological quality and field transposition excluded an additional 12 and 26 studies, respectively. Appendix II lists the studies that were rejected on full-text screening, methodological quality and field transposition assessments, together with the reasons for exclusion. Finally, a total of 91 citations met the eligibility criteria for inclusion in the systematic review. They reported on 114 studies, listed in Appendix III. Figure 1 shows the selection process workflow.

Agreement between reviewers was substantial at the abstract and title screening level (Kappa coefficient $=0.66, \mathrm{CI} 95 \%[0.58-0.75]$ calculated on $9.9 \%(366 / 3,715)$ of the identified citations), and almost perfect at the full-text screening level (Kappa coefficient $=0.92, \mathrm{CI} 95 \%$ $[0.78-1]$ on $14.3 \%(27 / 189)$ of the citations).

\subsection{Description of the included studies}

Among the 91 included citations, 82 were scientific journal articles, 6 unpublished study reports, 2 Ph.D. thesis reports, and 1 conference proceedings. Among the 114 included studies, almost half of the studies about M. edulis (44\%; 29/66) were conducted after 2015, whereas the annual number of studies on $M$. galloprovincialis varied regularly over the last 
decade (Figure 2). Almost one quarter of the studies about M. edulis were conducted in France, and about one third in North America (Figure 3a). For M. galloprovincialis, almost half of the studies were conducted in Southern Europe (particularly in Spain) and in South Africa (Figure 3b). Overall, the included studies aimed to understand mussel production losses $(45 \% ; 52 / 114)$, mussel species distribution and habitat segregation $(21 \% ; 24 / 114)$, or they used mussels as bioindicators to assess environment quality or climate change effects $(33 \% ; 38 / 114)$.

Table 2 describes the main characteristics of the corpus. The species $M$. edulis was mainly studied under observation conditions (58\%; 38/66 studies), whereas M. galloprovincialis was equally studied under either experimental or observation conditions $(48 \% ; 23 / 48$ and 52\%; 25/48 studies, respectively). For the two species, the studied populations were mainly farmed mussels or mussels from wild beds. The age class of the studied mussel populations was not reported for two thirds of the studies, as most of them rather described mussel size, especially for M. galloprovincialis. Only $34 \%$ of the studies showed a high methodological quality score to identify a risk factor. The vast majority of observation studies did not select the mussels at random (48/63), and used a study design with a low strength of proof to identify a risk factor (47/63). One quarter (13/51) of the laboratory studies did not use a control, and half of them $(26 / 51)$ did not reproduce the experiment in triplicate.

The first two factorial axes, which explained the larger amount of variance of all the 14 variables used to run the MCA, were used to interpret the pattern of relationships of the descriptive characteristics of the studies. They represented $28.0 \%$ of the total inertia (i.e. total variance of all variables included in the analysis), with $15.5 \%$ and $12.5 \%$ of variance explained, respectively. The 114 studies could be differentiated based on the modalities of all the variables used to run the MCA, except the geographical location, when the ellipses of the 
variable modalities were distinct (Figure 4). This figure also shows that the studies could be divided into two main groups. On the left quadrants, a first group gathered studies conducted on M. edulis in observational conditions, with a satisfactory methodological score, and investigating mortality risk factors pertaining to animal characteristics, and characteristics of the site and farming or harvesting practices. On the right quadrants, the second group gathered studies conducted on M. galloprovincialis in laboratory conditions in the Black Sea or the Mediterranean, exploring the effects of seawater characteristics and pollutants on the mussel mortality risk. The absolute contributions of the variables and their modalities are reported in Appendix IV.

\subsection{Definition and estimation of mussel mortality}

Even though all the 114 studies dealt with mussel mortality, a broad variation in terms of methodological approaches to define or estimate this outcome was found (Table 2). In laboratory studies, experimental mussel mortality was defined at the animal level as a binary outcome, the mussel being dead or alive. Half of the studies did not define criteria to assess the death of a mussel, and the other half used varying criteria. In the vast majority of observational studies, mortality was quantified at the mussel population level and expressed as a proportion, using a number of dead mussels as the numerator, and a total number of mussels as a denominator. For most of the studies in both mussel species (59/63), this proportion was a final prevalence or a cumulative prevalence, monitored throughout the study. No studies used mortality incidence as an outcome. To estimate the mortality proportion, most of the studies (52/63) used counts, but counting methods varied greatly among the studies. Almost three quarters of the studies measured mussel mortality regularly throughout the study course. Mussel mortality was mainly reported on a monthly basis in observational conditions, and on a daily basis in laboratory conditions. 


\subsection{Association measures between mortality and risk factors}

Studies used various statistical associations between the outcome of interest (mussel mortality) and the exposures of interest (e.g. factor modalities, treatments, concentrations) (Table 3). For qualitative factors of interest, comparison of mortality means, medians or proportions were used, whereas for quantitative factors of interest (e.g. chemical compound concentrations), several types of correlations were used. Laboratory studies, in particular those investigating the impact of pollutants, used substance concentrations causing $50 \%$ mortality $\left(\mathrm{LC}_{50}\right)$ within a fixed period of time (24 or 96 hours), or time leading to $50 \%$ mortality $\left(\mathrm{LT}_{50}\right)$.

\subsection{Risk factors for mussel mortality}

In total, 102 putative risk factors were examined in the 114 studies, with 62 factors for $M$. galloprovincialis (Table 4) and 67 factors for M. edulis (Table 5), pertaining to seven topics: pathogens, mussel characteristics, seawater characteristics, characteristics of the farming or fishing site, farming or harvesting practices, contaminants from the terrestrial and marine environments, and climate characteristics. The key results of the studies included in the following narrative review are provided in Appendix III.

\subsubsection{Factors related to pathogens}

The effect of pathogens on the mortality risk was studied equally in M. edulis (11 factors by 8 studies, Table 5) and in M. galloprovincialis (9 factors by 8 studies, Table 4).

In M. edulis, horizontal transmission of a putative causal agent of mortality was reproduced in laboratory conditions between two wild mussels stocks sampled after mortality events 
(Benabdelmouna et al., 2018). An additional experimental reproduction of this phenomenon was reported between wild mussels sampled after mortality events and sentinel hatchery produced mussels (Pépin et al., 2017). However, in both studies, pathogen identification was not successful.

Across the investigated pathogens in both mussel species, evidence of absence was consistently reported for Ostreid herpesvirus OsHV-1 (Benabdelmouna et al., 2018) and the OIE listed parasite Marteilia refringens (Bernard et al., 2018b ; Benabdelmouna et al., 2018). However, results reported for bacteria were not straightforward. In both mussel species, no effect of the overall bacteriological profile of the mussels was shown on the mortality risk (Bernard et al., 2018b). In M. edulis, the bacterium Vibrio aestuarianus was not detected in moribund mussel tissues (Benabdelmouna et al., 2018), whereas a possible association with mortality risk was suspected for anaerobic bacteria (Babarro \& De Zwaan, 2008), opportunistic heterotrophic bacteria present in the seawater (Eggermont et al., 2014), or bacteria belonging to the genus Photobacterium (Eggermont et al., 2017). Bacteria belonging to the Splendidus clade of the genus Vibrio were inconsistently detected in moribund mussel tissues or haemolymph, challenging their role in mortality risk (Benabdelmouna et al., 2018 ; Eggermont et al., 2017). In M. galloprovincialis, conflicting results were reported regarding the effect of the presence of bacteria Vibrio aestuarianus or Vibrio belonging to the Splendidus clade on the mortality risk, even when mussels were exposed to high concentrations of bacteria in the seawater $\left(10^{10} \mathrm{CFU} \cdot \mathrm{mL}^{-1}\right)$ (Romero et al., 2014). To induce mussel mortality, additional exposures to an elevated temperature of the seawater $\left(25^{\circ} \mathrm{C}\right)$, and to 8 hours emersion to reproduce hypoxia stress were needed. 
Algae effects were also investigated. Lethal effects of toxic dinoflagellate algae were reported in M. galloprovincialis with Ostreopsis cf ovata (Carella et al., 2015) and in M. edulis with Karlodinium armiger (Binzer et al., 2018). On sheltered rocky shores, the presence of epibiotic algae on the shell was reported to increase the mortality risk in both mussel species (O'Connor, 2010). In M. galloprovincialis, conflicting results were reported concerning the effect of parasitic phototrophic shell-degrading endoliths, showing a protective effect against heat stress mortality by decreasing their body temperature (Zardi et al., 2016), or a sub-lethal effect because of induced shell weakening (Marquet et al., 2013) or of energy trade-off between shell repair and other physiological constraints (Nicastro et al., 2018).

\subsubsection{Factors related to mussel characteristics}

The effect of mussel characteristics on the mortality risk was more commonly studied in $M$. edulis (15 factors by 22 studies, Table 5) than in M. galloprovincialis (4 factors by 7 studies, Table 4).

Among these factors, genetic characteristics were the main factors investigated, in particular species and genotype. The mortality risk of M. edulis did not differ from that of M. trossulus in field conditions (Lowen, 2008 ; Penney et al., 2006), whereas it was lower in a laboratory study reproducing coastal and estuarine conditions (Gardner \& Thompson, 2001). In the field, the mortality risk of $M$. galloprovincialis did not differ from that of $M$. trossulus (Shields et al., 2008), whereas a lower mortality risk was observed in two laboratory studies where animals were exposed to either air or seawater thermal stress (Dowd \& Somero, 2013 ; Schneider, 2008). In M. galloprovincialis, the effect of the genotype on the mortality risk depended on the species crossed. On the one hand, the mortality risk of mussels having a hybrid genotype of $M$. galloprovincialis and M. trossulus showed no difference when 
compared to pure native M. trossulus and to pure introduced M. galloprovincialis (Shields et al., 2008). On the other hand, hybrids of M. galloprovincialis and M. edulis showed a higher mortality risk than the populations from pure crosses (Fuentes et al., 2002). Hybrids of $M$. edulis and M. trossulus also showed a higher mortality risk than the pure populations (Lowen, 2008). In M. edulis, a selected intraspecific genotype showed inconsistent effects on mortality risk, perhaps depending on the number of selected generations. In fact, the first selected generation, i.e. the survivor mussels of a preceding mortality event, still presented an increased mortality risk in subsequent years (Myrand \& Gaudreault, 1995), whereas two studies reported a lower mortality risk for spat descending from parents that had survived a previous mortality event, compared to spat with a non-selected genotype (Pépin et al., 2017 ; Pépin et al., 2018). A low degree of multiple-locus heterozygosity was associated with an increased risk of mortality in M. edulis (Tremblay et al., 1998). A high percentage of genomic abnormalities in haemocytes was found to be associated with an increased mortality risk in $M$. galloprovincialis (Benabdelmouna \& Ledu, 2016) ), although inconsistent association was reported in M. edulis (Benandelmouna and Ledu, 2016 ; Pépin et al., 2017 ; Pépin et al., 2018).

Physiological characteristics were also explored, mainly in M. edulis. The effect of mussel size on the mortality risk was the most commonly investigated factor. Although no effect was observed in the two studies on M. galloprovincialis (Lok et al., 2007 ; O'Connor, 2010), inconsistent results were reported for the effect of this trait on the mortality risk of M. edulis. Discrepancies may be explained by different study conditions: mussel size was sometimes studied in combination with hypoxic conditions (Altieri \& Witman, 2006), in the context of new socking material to protect mussels from predation (Dionne et al., 2006), or in the context of exploration of massive mortalities of wild beds (Tsuchiya, 1983) or cultivated 
mussels (Tremblay et al., 1998). A study also explored the effect of the initial seed size, showing that small seed had a higher mortality risk than larger seed (Lauzon-Guay et al., 2005). These types of differences in study conditions prevented any direct comparison or synthesis of the results. Individual traits related to a poor condition were also investigated in M. edulis to a lesser extent. A low condition index (Hiebenthal et al., 2013), low energy reserves due to depleted reserves after spawning (Myrand et al., 2000), and high bio-energetic needs for maintenance metabolism (Tremblay et al., 1998) were reported to be associated with an increased mortality risk in M. edulis. This is further supported by reported synchronous timing between mortality and gametogenesis (Pépin et al., 2017), when the mussels use high bio-energetic resources for reproduction.

\subsubsection{Factors related to seawater characteristics}

The effect of seawater characteristics on the mortality risk was more often studied in $M$. edulis ( 8 factors by 17 studies, Table 5) than in M. galloprovincialis (5 factors by 9 studies, Table 4).

In $M$. galloprovincialis, these factors were exclusively studied under laboratory conditions. As the only study showing no effect of the seawater temperature (Gestoso et al., 2016) tested a maximum temperature of $21^{\circ} \mathrm{C}$, the mortality risk seemed to increase above a value of this factor of $\approx 24^{\circ} \mathrm{C}$ (Anestis et al., 2007 ; Dowd \& Somero, 2013 ; Gazeau et al., 2018). In $M$. edulis, the mortality risk was associated with a thermal threshold of $\approx 20^{\circ} \mathrm{C}$ (Incze et al., 1980

; Jones et al., 2010 ; Hiebenthal et al., 2013 ; Cottrell et al., 2016 ; Hutchison et al., 2016 ; Clements et al., 2018 ; Lenz et al., 2018 ; Wang et al., 2018 ; Bernard et al., 2018a). The two studies showing no association between an elevated temperature and mussel mortality risk explored the effect of this factor in combination with other simultaneous exposures: to 
zinc or cadmium (Ali \& Taylor, 2010) or to a decreased $\mathrm{pH}$ and decreased oxygen concentration in water (Stevens \& Gobler, 2018). The interactions with other stressors may have compensated the effect of the elevated seawater temperature on the mortality risk. Moreover, Ali and Taylor (2010) used lower values of the seawater temperature than the other studies $\left(6^{\circ} \mathrm{C}\right.$ and $\left.12^{\circ} \mathrm{C}\right)$. Exposure to a cold temperature of $4^{\circ} \mathrm{C}$ also increased the mortality risk of $M$. edulis (Wang et al., 2018). Opposite results were reported for the effect of an increasing number of thermal stresses on the mortality risk of M. edulis (Jones et al., 2009 ; Lenz et al., 2018), whereas no effect was observed in M. galloprovincialis (Lenz et al., 2018).

In both mussel species, an increased mortality risk was reported with low salinity values (20 and 28 practical salinity units, psu) in laboratory conditions (Hamer et al., 2008 ; Ali \& Taylor, 2010), which may sometimes be observed in field conditions in a wide desalination context.

Among seawater characteristics, the effect of acidification of seawater showed conflicting results in both mussel species, probably because of the broad variation in laboratory conditions (levels of $\mathrm{pH}$ tested, exposure duration, or acute vs. gradual exposure). Low levels of seawater $\mathrm{pH}$ increased the mortality risk of M. edulis (Sun et al., 2016 ; Stevens \& Gobler, 2018), whereas one study reported no effect of elevated $\mathrm{CO}_{2}$ concentrations (Clements et al., 2018). However, no effect was observed when this factor was combined with a low level of dissolved oxygen or with an elevated temperature, suggesting antagonist interactions between these stressors (Stevens \& Gobler, 2018). In M. galloprovincialis, extended exposure (6 months) of mussels to a low level of $\mathrm{pH}$ was associated with an increased mortality risk, whereas shorter exposure (3 months) did not show any effect (Bressan et al., 2014). Acute exposure to acidification was associated with an increased mortality risk (Gestoso et al., 
2016), whereas gradual acclimation to similar lowered $\mathrm{pH}$ over a few weeks did not show any effect (Gazeau et al., 2018).

Low levels of dissolved oxygen in seawater did not show any effect on the mortality risk of M. edulis (Stevens \& Gobler, 2018). In M. galloprovincialis, hypoxia-induced stress, reproduced in laboratory conditions using an 8-hour emersion treatment, increased the risk of mortality when mussels were also simultaneously exposed to pathogens and to an elevated seawater temperature of $25^{\circ} \mathrm{C}$ (Romero et al., 2014).

Concerning seawater characteristics, the effect of food availability (quantity and quality) was also explored in M. edulis. A rapid decrease in the quantity of phytoplankton preceded mortality onset (Incze et al., 1980), leading the authors to suggest that the mortalities may be triggered by reduced ration and starvation. A decline in indicators of phytoplankton species richness (Shannon index and total abundance) was also reported before mussel mortality onset (Travers et al., 2016).

\subsubsection{Factors related to characteristics of the farming or fishing site}

The effect of characteristics of the farming or fishing site on the mortality risk was more commonly studied in M. edulis (10 factors by 25 studies, Table 5) than in M. galloprovincialis ( 8 factors by 14 studies, Table 4 ).

In both mussel species, broad spatial variation in the mortality risk between different farming or fishing sites was reported in several studies (Fuentes et al., 1994 ; Penney et al., 2006 ; Bownes \& McQuaid, 2010 ; Gardner, 2013 ; Travers et al., 2016 ; Glize et al., 2017 ; Moschino et al., 2017 ; Pépin et al., 2017 ; Bernard et al., 2018b ; Glize \& Gourmelen, 2018 
; Pépin et al., 2018), whereas other studies did not observe a mortality risk variation across locations (Fuentes et al., 1992 ; Myrand \& Gaudreault, 1995 ; Stirling \& Okumus, 1994 ; Lauzon-Guay et al., 2005 ; Mallet et al., 1987 ; Mallet et al., 1990). However, except in one study which explored mussel position on the shore (Bownes \& McQuaid, 2010), the characteristics of the geographical sites potentially explaining this variation were never detailed.

Some site characteristics have been studied, specifically to understand species invasion or habitat segregation of several mussel species. In M. galloprovincialis, characteristics of mussel wild beds have been explored to evaluate the effects of hydrodynamic stress and sand stress, by comparing bay and open coast habitats. An increased mortality risk was reported in open coast conditions (Nicastro et al., 2008 ; Nicastro et al., 2010) and when the shore was exposed to waves (O'Connor, 2010). No effect of the position of mussels in the bed, either at the edge or in the centre, was observed (Nicastro et al., 2008). Wave height was found to be a risk factor of mortality in a bay habitat (Nicastro et al., 2010 ; Zardi et al., 2008), whereas it had no effect in open coast conditions (Nicastro et al., 2010). Sand accumulation on mussel beds, either because of sand burial or suspended sand in the seawater, was associated with an increased mortality risk in two studies (Zardi et al., 2006 ; Nicastro et al., 2010). However, one study showed no effect of this factor (Zardi et al., 2008). In M. edulis, sediment parameters were investigated in particular. Mortality increased with increasing duration of burial (Hutchison et al., 2016 ; Cottrell et al., 2016), but conflicting results were reported for the effect of the depth of burial (Hutchison et al., 2016). Fine sediment fractions (Hutchison et al., 2016 ; Cottrell et al., 2016) and high concentrations of organic matter in the sediment (Cottrell et al., 2016) were associated with an increased mortality risk. 
Emersion stress has also been explored in various studies. No effect of the mussel bed position on the shore was reported for M. galloprovincialis (Bownes \& McQuaid, 2010 ; Marquet et al., 2013), whereas mortality risk increased in M. edulis on higher tidal height in the context of snail predator activity (Petraitis, 1998) or of heat wave exposure (Tsuchiya, 1983).

The presence of predators on the farming or fishing site was studied either to explain mussel mortalities (for example crabs (Brousscau et al., 2014 ; Christensen et al., 2012) and diving ducks (Dionne et al., 2006) for M. edulis; flatworm (Gammoudi et al., 2017), and benthic and pelagic predators (Plass-Johnson et al., 2010) for M. galloprovincialis) or to understand the absence of mussels at a certain level of rocky shore, e.g. hypothetically due to the activity of the snail Nucella lapillus (Petraitis, 1998).

The mortality risk due to predation was reduced in reefs with small inter-structural spaces (Bertolini et al., 2018). One study showed that the presence of the Pacific oyster (Crassostrea gigas) deterred predator attacks from mussels and reduced their mortality risk (Waser et al., 2015).

\subsubsection{Factors related to farming or harvesting practices}

The effect of farming or harvesting practices on the mortality risk was more closely studied in M. edulis (15 factors by 22 studies, Table 5) than in M. galloprovincialis ( 8 factors by 13 studies, Table 4).

Concerning farming practices, the geographical origin of the seed was mainly investigated. Several studies reported an effect of this factor on the mortality risk of M. edulis (Myrand \& Gaudreault, 1995 ; Mallet et al., 1987 ; Mallet et al., 1990 ; Bernard et al., 2018a), whereas 
other studies showed no effect (Glize et al., 2017 ; SMIDAP, 2016-2017 ; Glize \& Gourmelen, 2018). In particular, the effect of seed translocation on the mortality risk was explored. This farming practice, widely spread across the world in aquaculture, consists in transplanting mussel spat to areas with favourable conditions for growth (Aypa, 1990). In $M$. edulis, most of the studies reported no effect of this practice on the mortality risk (Penney et al., 2006 ; Myrand \& Gaudreault, 1995 ; Mallet et al., 1987 ; Fuentes et al., 2002 ; Mallet et al., 1990 ; Glize et al., 2017 ; SMIDAP, 2016) although one study reported reduced mortality in mussel spat collected on-site compared to translocated spat (SMIDAP, 20162017). In M. galloprovincialis, almost all the studies reported translocated spat having a higher mortality risk than local spat (Ramon et al., 2007 ; Gardner, 2013 ; Fuentes et al., 1992 ; Ajjabi et al., 2018 ; Fuentes et al., 1994 ; Kovacic et al., 2017 ; Bernard et al., 2018a). Only one study, conducted in the context of understanding the spatial distribution of native, introduced and hybrid Mytilus sp. (Shields et al., 2008), observed a different result. The authors suggested that translocation to a site with cooler water temperatures decreased the mortality risk by reducing thermal stress.

A protective effect of a thermal challenge, either using elevated water temperature or air exposure before their deployment to the farming sites, was reported on M. edulis spat (LeBlanc et al., 2008). The authors suggested a selective effect of this treatment by selecting mussels with higher levels of heterozygosity, providing them more physiological flexibility.

The effect of the initial farming density on the mortality risk of M. edulis was controversial, with one study reporting no short-term effect ( 3 months), but a long-term effect (10 months) (Lauzon-Guay et al., 2005). Interestingly, another study reported no effect of this factor after 15 months (Lowen, 2008). 
Regarding other farming practices, the effect of different suspended farming structures on the mussel mortality risk was investigated. In M. edulis, no effect of the depth of the lantern nets in a suspended raft was reported (Karayucel \& Karayucel, 2000), whereas mussel mortality risk was higher in suspended mesh plastic cages maintained deeper in the open sea (14 m depth) than in the lagoon (4 $\mathrm{m}$ depth) (Myrand et al., 2000). Conflicting results about the effect of the position of the mussels within a suspended raft on their mortality risk were reported, with studies showing no effect of this factor for both species (Karayucel \& Karayucel, 2000 ; Fuentes et al., 1992) or a higher mortality risk in the fore-part than the aftpart of the suspended raft in M. galloprovincialis (Fuentes et al., 1994).

A few studies focused on the effects of certain commercial husbandry practices regarding mussel transportation to the market. In M. galloprovincialis, no effect of the stocking density during re-immersion into seawater after harvesting and grading and before transport was reported (Theodorou et al., 2017). Re-immersion beyond 11 days increased the mortality risk (Theodorou et al., 2017). In M. edulis, re-immersion before transport did not have a significant effect on the mussel mortality risk, whether they were stored with ice or at a chilled ambient temperature of $5^{\circ} \mathrm{C}$ during transport, at any stage of the supply chain (pretransportation or post-transportation) (Barrento \& Powell, 2016). Mussels being re-immersed before transport and stored on ice showed reduced mortalities compared to mussels being not re-immersed before transport and stored at ambient temperature (Barrento \& Powell, 2016).

All aspects of mussel culture are impacted by tunicate fouling and the effect of anti-biofouling chemical treatments to mitigate their consequences on the mussel mortality risk was also studied. Results showed that the potassium monopersulphonate triple salt based disinfectant 
(Virkon ${ }^{\circledR}$ Aquatic) has no significant effect on mussel mortality until three weeks posttreatment (Paetzold \& Davidson, 2011). Vinegar, brime or lime could also be applied either before transportation, followed or not by a seawater rinse, or after transportation without provoking an increased mussel mortality risk (Vickerson, 2009).

When predation was the acknowledged mortality cause in M. edulis, some studies tested solutions to limit its impact on mussel production, e.g. use of mussels collected in suspended culture versus mussels collected from natural bottom mussel beds for bottom culture production, despite the presence of crabs (Christensen et al., 2012), or protective socking material to protect mussels from diving ducks (Dionne et al., 2006).

Farming mixed mussel species, i.e. M. edulis and M. trossulus (Lowen, 2008) or $M$. galloprovincialis and Xenostrobus securis (Gestoso et al., 2016 ; Olabarrial et al., 2016) was found to lower the mortality risk. Integrated multi-trophic aquaculture (IMTA) showed a lower mortality risk for M. galloprovincialis when mussels were cultivated with algae (Ajjabi et al., 2018), but did not show any effect when mussels were farmed with fishes (Gvozdenovic et al., 2017).

On wild beds, the intensive human trampling during harvesting of $M$. galloprovincialis increased mussel mortality, particularly when mussels were infested with parasitic endoliths (Nicastro et al., 2018).

3.5.6. Factors related to contaminants from the terrestrial and marine environments 
The effect of terrestrial or marine pollutants on the mortality risk was studied more frequently in M. galloprovincialis (24 factors by 7 studies, Table 4) than in M. edulis (4 factors by 3 studies, Table 5).

All chemical compounds tested in laboratory conditions showed a lethal effect on mussels $(M$. edulis: (Suni et al., 2007 ; Akaishi et al., 2007 ; Ali \& Taylor, 2010); M. galloprovincialis: (Danellakis et al., 2011 ; Li et al., 2018 ; Oliveira et al., 2017 ; Rosen \& Lotufo, 2007 ; Tsarpali et al., 2015 ; Tsarpali \& Dailianis, 2012), except for two explosive compounds in $M$. galloprovincialis (Rosen \& Lotufo, 2007). Most of these studies mimicked pollution events. Only one study investigated the effect of several chemical compounds on the mortality risk of M. galloprovincialis in field conditions, in Italy (Moschino et al., 2016). This may be explained because it is easier to control these parameters in laboratory conditions. Results showed that concentrations in mussel soft tissues of aluminium, iron, lead and polycyclic aromatic hydrocarbons (PAHs) were correlated with the mussel mortality rate. The other 11 metals and micro-organic pollutants detected in mussel samples showed no association with mussel mortality (Moschino et al., 2016).

\subsubsection{Factors related to climate characteristics}

The effect of climate characteristics on the mortality risk was studied equally in both mussel species ( 4 factors by 8 studies, Tables 4 and 5).

In both mussel species, wide seasonal variations in the mortality risk were reported in several studies (Myrand et al., 2000 ; Nicastro et al., 2008 ; Nicastro et al., 2010 ; Bernard et al., 2018a) except for one (Mallet et al., 1987). Risky seasons varied across the hemispheres and 
were not necessarily the warmest ones, particularly in South Africa where mortality peaks were reported during winter (Nicastro et al., 2010).

Aerial temperature was the main seasonal factor investigated, often in the context of stress responses and exploration of physiological capacities to explain species invasion or habitat segregation of several mussel species. In M. edulis, the mortality risk increased with increasing air temperature in the context of heatwave exposure (Tsuchiya, 1983), rising high summer temperatures (Jones et al., 2010) or in laboratory conditions (Jones et al., 2009). Only one study showed no effect of elevated air temperatures on the mussel mortality risk (Travers et al., 2016), but the seasonal temperature variation reported was much less contrasted than in the other studies. In M. galloprovincialis, heatwave exposure above $27^{\circ} \mathrm{C}$ was also reported to be associated with an increased mortality risk (Olabarrial et al., 2016). Conflicting results were reported for the effect of an increased number of aerial thermal stresses, with studies showing an increased mortality risk in M. edulis (Jones et al., 2009 ; Jones et al., 2010), a decreased mortality risk when the mussels had previously been exposed to chronic chemical contamination (Peden et al., 2018), or no effect in M. galloprovincialis (Dowd \& Somero, 2013). In M. galloprovincialis, the thermal range between air and water temperature exposures showed inconsistent effects on the mortality risk between the laboratory studies (Anestis et al., 2010 ; Dowd \& Somero, 2013 ; Schneider, 2008), probably because of the heterogeneity of the ranges investigated, varying from $2^{\circ} \mathrm{C}$ to $20^{\circ} \mathrm{C}$.

\subsubsection{Interactions between factors}

Among the 114 studies, only one quarter $(28 / 114 ; 25 \%)$ investigated the effect of interactions between exposure factors on the mussel mortality risk. This represented $30 \%$ of the studies (20/66) on M. edulis, and $17 \%$ of the corpus (8/48) on M. galloprovincialis. In both species, 
these studies were conducted to the same extent in observation or in laboratory conditions. Almost two thirds of these studies (17/28) explored the combined effect of three factors, while another third (11/28) investigated interactions between two factors. In M. galloprovincialis, the most frequently studied interactions fell under site characteristics, while in M. edulis, interactions were explored for exposures pertaining mainly to mussel and site characteristics, and husbandry or fishery practices (Figure 5).

Synergistic effects, i.e. a combined effect greater than the sum of the individual effects of the exposure factors, were reported on mussel mortality risk. In M. galloprovincialis, a synergistic effect was reported between exposure of mussels to high concentrations of bacteria Vibrio aestuarianus or Vibrio belonging to the Splendidus clade in seawater, an elevated seawater temperature $\left(25^{\circ} \mathrm{C}\right)$, and to 8 -h emersion to mimic hypoxia-induced stress (Romero et al., 2014). Trampling and endolith-infestation were reported to act together to increase the mortality risk in large M. galloprovincialis mussels (Nicastro et al., 2018). In $M$. edulis, a synergistic joint-effect was observed with exposure to heavy metals (cadmium or zinc) in combination with low salinity and high temperature of seawater (Ali \& Taylor, 2010). In this species, the negative impact of enrichment of sediment with organic matter on mussel mortality was exacerbated in conditions of burial in fine sediments (Cottrell et al., 2016).

Antagonistic effects, i.e. combined effects lower than the sum of the individual effects of the exposure factors, were also reported, particularly among seawater characteristics. In $M$. edulis, antagonistic effects were observed between low levels of $\mathrm{pH}$ and dissolved oxygen (Stevens \& Gobler, 2018), low levels of pH, low levels of dissolved oxygen and elevated seawater temperature (Stevens \& Gobler, 2018), and between elevated seawater temperature and elevated seawater $\mathrm{CO}_{2}$ concentrations (Clements et al., 2018). In M. galloprovincialis, 
such antagonistic effects were reported between a lowered $\mathrm{pH}$ and an elevated seawater temperature (Gazeau et al., 2018).

Other non-specific interactions were reported, with exposure factors modulating the individual effect on the mussel mortality risk of another factor, without a straightforward overall interpretation when multiple factor interactions were reported. In both mussel species, interactions were reported between the presence of algal epibionts and the wave exposure of the shore, showing a negative effect of epibiotic algae on mussel survival on sheltered shores (O'Connor, 2010). In M. galloprovincialis, a decreased effect of a lowered $\mathrm{pH}$ of the seawater was reported on the mortality risk when animals were clumped with mussels of another species Xenostrobus securis (Gestoso et al., 2016). Another study showed a negative effect of decreased seawater salinity on the mussel mortality risk, only if associated with an elevated temperature (Hamer et al., 2008). In the context of the understanding of the success of $M$. galloprovincialis as an invasive species in South Africa, interactions were reported between the location, site or zone on the mussel mortality risk (Bownes \& McQuaid, 2010 ; Marquet et al., 2013). In M. edulis, three studies explored solutions to limit the impact of predation on mussel production or populations, and found statistically significant interactions between mussel size and either farming material by showing that protective socking material was more efficient in large mussels against diving ducks (Dionne et al., 2006), characteristics of the site by reporting that clumped habitats were more protective for small mussels against crab or starfish (Bertolini et al., 2018), or the presence of oysters Crassostrea gigas by showing that this presence significantly reduced the mortality of small sized mussels, but the effect varied according to crab size (Waser et al., 2015). Another study reported the effect of hypoxiainduced stress on mussel mortality to be size-specific, with larger mussels having an increased mortality risk under hypoxia conditions than smaller ones (Altieri \& Witman, 2006). Gradual 
acclimation of the mussels to warmer temperatures modulated the effect on $M$. edulis mortality of the combined exposure of mussels to chronic chemical contamination and acute heat stress (Peden et al., 2018). The effect of the initial farming density on the mortality risk was modulated by mussel size, with mortality of small seed generally increasing with increasing initial density, while mortality of large seed was not affected by initial farming density (Lauzon-Guay et al., 2005). Interactions between the geographical origin of the spat and mussel age were reported on the M. edulis mortality risk (Mallet et al., 1990). Along the supply chain, interactions between non-depuration treatment before transport and ambient temperature treatment during transport were reported concerning the mortality risk of $M$. edulis mussels at the post-rewatering stage (Barrento \& Powell, 2016).

Non-significant interactions were also observed, for example between duration of burial and the sediment fraction size, or between the duration of burial and the temperature of the seawater concerning the mortality risk of M. edulis (Hutchison et al., 2016), in the context of sudden deposited sediment on the mussel bed.

Conflicting results were reported about the interaction effect of mussel stock origin (i.e. genotype) and site on the mortality risk of $M$. edulis, with some studies reporting a significant interaction (Penney et al., 2006 ; Mallet et al., 1987 ; Fuentes et al., 1992), and one study reporting no interaction (Myrand \& Gaudreault, 1995). 


\section{Discussion}

The aim of this systematic review was to summarize the findings from the literature that report risk factors for mortality of marine mussels M. edulis and M. galloprovincialis. The motivation for this study was to provide science-based information to inform actionable solutions to mitigate, or even prevent, mussel mortalities.

\subsection{Literature heterogeneity}

The literature reviewed was highly heterogeneous. Across the corpus, there was considerable variability among studies with respect to methodological approaches used to define or estimate mussel mortality, and to define putative mortality risk factors and exposure metrics.

Although a systematic review question should be focused and explicit (European Food Safety Agency, 2010), the present review question was broad in scope due to the wide range of risk factors to be considered, as requested by the French Ministry in charge of Agriculture (Anon, 2016). Members of the Scientific and Technical Council (STC) were not aware of large volumes of literature on studies formally designed to identify risk factors of mussel mortality pertaining to different topics. The literature search strategy was thus chosen to be highly sensitive and not too specific to ensure that it captured most information regarding the factors associated with mussel mortality, even though this was not the main objective of the studies. Only $2.4 \%$ of the identified unique citations were ultimately selected as relevant. In fact, less than half of the included studies aimed to understand mussel production losses and were thus likely to identify potential risk factor that could be used to inform actionable solutions to mitigate or prevent mussel mortalities. The included studies were roughly concerned either with understanding mussel species distribution and habitat segregation, or used mussels as bioindicators to assess environment quality or climate change effects. Although these 
concerns are not completely separate, one does not replace the other and results cannot systematically be extrapolated to mussel mortality risk. Additionally, within the selected corpus, there were only a few studies with a high level of methodological quality in the STC assessment. Importantly, none of the identified studies applied the full set of known standards of epidemiological research (Martin et al., 1987), and none explored the effect of several risk factors pertaining to different topics and their interactions on mussel mortality in field conditions. The final corpus, made of 91 publications corresponding to 114 studies and belonging to many different research disciplines, integrated the diverse streams of evidence, observational studies and experimental information. These studies were conducted in experimental or observational conditions, and required different standards, norms and constraints to report mortality and to characterise exposures. Designs and end-points were thus diverse and were subject to research objectives.

Another cause of heterogeneity between the results of the studies was the mussel species considered. This was expected because geographical range, ecology, physiology or functional traits differ between M. edulis and M. galloprovincialis. Multiple correspondence analysis showed a split of the corpus in two groups based on mussel species in particular. Thus, the results of the present review were separated by mussel species.

As a consequence, knowledge was too heterogeneous to be summarised in a quantitative manner; notably aggregating these heterogeneous results into a meta-analysis was not possible. Therefore, the review results were interpreted and discussed narratively.

\subsection{Risk factor identification and ranking}


In this systematic review, more than 100 factors related to mussel mortality were identified, which highlights the diversity of variables that researchers considered as potential risks or protective factors in mussel mortality. However, it is interesting to note that although some factors coincided between studies, these were not repeated in a large number of studies. As detailed above, the small number of studies and the diversity of the definitions and exposure metrics captured for a given risk factor prevented any meta-analysis and quantification of effects on the mussel mortality risk. Therefore, comparisons of the strengths of association between mussel mortality and factors, and the subsequent ranking of risk factors were not possible. Moreover, the number of studies was artificially increased for some factors, when the same research group published several papers, or several studies in the same paper on the same subject. This publication bias limited the relevance of an evidence interpretation strictly on a quantitative basis, i.e. the number of studies, and thus prevented the use of the vote counting method (Allen, 2017) for establishing a ranking of the risk factors.

Even when looking at the studies that explored one particular factor, there was not often consistent evidence of an overall qualitative effect on the mussel mortality risk. Nevertheless, this systematic review highlighted that the mortality risk of both mussel species M. edulis and M. galloprovincialis varied across the seasons. It furthermore acknowledged the negative impact of an increased seawater temperature with a thermal threshold of $20^{\circ} \mathrm{C}$ and $24^{\circ} \mathrm{C}$, respectively. The mortality risk of $M$. edulis could also be associated with pathogens. However, these risk factors relate to the impacts of global changes in ocean and coastal ecosystems (Burge et al., 2014 ; IPCC (Intergovernmental Panel on Climate Change), 2019) and cannot be changed. Therefore, although this systematic review was comprehensive, it offered limited evidence to define actionable control or mitigation strategies of mussel mortality either for policy-making, mussel industry, or wild bed conservation. For $M$. 
galloprovincialis, the preventive husbandry practices would be using mussel spat from the same area where the farming is carried out, protecting mussels from predation, or farming together with another mussel species, if possible. For M. edulis, they would be protecting mussels from predation, using pure crosses and particulary mussel spat having a selected genotype, i.e. parents that survived a previous mortality event, whether the selection was natural or anthropic. For wild bed conservation of both mussel species, the impacts of marine anthropic factors, e.g. the activities of the marine aggregate extraction industry (Barrio Frojan et al., 2008), marine renewable energy technology (Miller et al., 2013) or dredging to maintain access to harbours, should be evaluated ex ante before their implementation, to minimise anthropogenic sedimentation or sand accumulation on wild beds.

\subsection{Review limitations}

Although the systematic review is an unbiased approach, the present study is subject to a few limitations that are mainly explained by the trade-off between limited resources and risk of error.

Only one reviewer read the full content and conducted the data extraction from the corpus considered in this systematic review, ensuring homogeneous data analysis across the whole corpus. However, to limit the risk of errors in data extraction, pilot-tests and standardised extraction forms were used. In addition, the STC implemented collective study selection based on the title and abstract screening and data extraction verification based on random samples of the studies, respectively $9.9 \%$ and $14.3 \%$ of the corpus. The agreement between the reviewers was substantial at the abstract and title screening level and almost complete at the data extraction stage, showing that selection or measurement bias were unlikely to have affected the review results. 
The language restriction applied (French and English), due to the lack of resources to translate other languages, biased the study selection towards English and French speaking countries. It is possible that knowledge from some regions of the world has been under-represented, specifically data from Spain which is the main European producer of mussels (FAO, 2019).

This review included some subjective interpretation as risk factors were rarely the main focus of the included studies. Effectively, translation of concepts across studies was subject to reviewer interpretation. We are therefore confident that our interpretation accurately reflects the data, although we agree that other interpretations are possible and may be equally valid.

Because this review covered a wide range of risk factors, the findings are at a high level of aggregation; a focus on more specific exposure topics would have allowed for more in-depth evaluation. 


\section{Research gaps and future directions}

This literature review revealed significant gaps in knowledge of marine mussel risk factors, which led the STC to develop recommendations for future research to be undertaken on mussel mortality determinants.

\subsection{Develop standardised methodologies to estimate mortality in the field}

The first recommendation involves the development of standardised methodologies to estimate mussel mortality in the field, which use shared epidemiological indicators. This literature review showed high heterogeneity to define and estimate mortality in mussels, which is not solely explained by the different standards required by the numerous research disciplines. In particular, technical constraints that challenge mortality estimation in mussel populations, notably in farming conditions, have so far precluded the standardised estimation of mortality. Similarly, the large population sizes and the difficulties in gaining access to the animals prevent robust estimation of epidemiological indicators, since accurately measuring the numbers of dead animals (numerator) and the total population size (denominator) is challenging (Peeler \& Taylor, 2011 ; Lupo et al., 2012). In addition, mortality is rarely homogeneously distributed in such large populations, which prevents simple application of representative sampling. Thus, and unfortunately, it seems that regardless of the innovative tools that could be developed, accurately counting dead and live mussels to calculate a mortality proportion would still be an issue. A shift in the paradigm to estimate mussel mortality is thus needed, and scaling of the concept may be a possible solution.

Marine bivalves share many epidemiological challenges with honey bees. In the context of the French surveillance programme of massive bee mortality, bee mortality is defined at the apiary level using a two-step approach over a 15-day period (Anon, 2018). A bee operation 
owned or managed by one beekeeper is made of several apiaries, which consist of several bee colonies located in the same area, themselves made up of a group of individual bees. The first step consists in assessing a bee colony as "dead" if more than one litre of dead bees is observed in front of the hive or if the colony is depopulated. The second step involves considering the apiary to be "dead" if more than $20 \%$ of its forming colonies are dead. For medium apiaries (from 6 to 10 colonies), it is considered dead if two dead colonies are observed. For small apiaries (from 2 to 5 colonies), it is considered dead if one dead colony is reported (Anon, 2018). Therefore, to obtain an accurate estimation of mortality at the population level, based on the observed mortality on the sampled colonies, calculation of the mortality proportions is related to the size of the apiaries. Honeybee colony mortality is a weighted average, by apiary size, of the colony mortality proportion of each apiary (Chauzat et al., 2016). The STC believes that the marine mussel community should consider this type of approach of (1) assessing mortality at a farming unit level, instead of the accurate individual animal scale, and (2) combining qualitative and quantitative criteria within a defined time period (e.g. a tide cycle). It is considered that a mussel farm owned by one mussel farmer is made of several farming places, e.g. leasing grounds, which consist of several farming structures i.e. "bouchot" for M. edulis or raft for M. galloprovincialis, themselves made of a group of individual mussels. Thus, a multistage sampling plan may be adapted to estimate mortality at each unit of interest by accounting for the unit hierarchy. At each unit level, thresholds to assess whether the unit is affected by mussel mortality (i.e. “dead") could be defined by using standardised semi-quantitative criteria.

\subsection{Use study designs that can address multiple interactions between risk factors}

The second recommendation concerns the application of study designs adequately addressing the identification of many interacting mussel mortality risk factors pertaining to different 
topics, since the methodological quality assessment revealed frequent weaknesses in the reviewed corpus. More data are required on the combined effects of multiple risk factors. For this approach to succeed, there is a need for concomitant collection, i.e. at the same time and in the same place, of data on multiple exposures of different types. The essential concept should be to compare the exposure profiles of dead versus healthy mussel populations, and over time, to provide valuable clues about the risk factors of mortality. A preliminary approach would be the development of eco-epidemiological studies, which aim to analyse determinants and outcomes at different levels of organisation of the studied system, from the molecular to the social (Susser \& Susser, 1996). These should necessarily be integrative and multidisciplinary to cover all the different risk factor topics. Guidelines to design and report epidemiological studies (STROBE-Vet) should be used (Sargeant et al., 2016). A second approach would be the development of mesocosm experiments, which are used to simulate complex exposure dynamics under realistic field conditions (Culp et al., 2017). Mesocosms are a hybrid of field and laboratory conditions; their advantages include increased control and replication compared to field studies and more realistic conditions than laboratory experiments. Currently, these approaches are used to study the effects of contaminants in the marine ecosystem (Alexander et al., 2016). Once this screening step of potential risk factors is achieved, targeted experimental approaches could be developed further to assess their causality while controlling the other factors.

\subsection{Integrate the concept of exposome}

The third recommendation includes the integration of the concept of exposome, i.e. every exposure to which an individual is subjected from conception to death (Wild, 2005), in future investigations undertaken on multiple exposure-mortality associations in mussels. This literature review showed that only one third of the studies had explored the combined effects 
of multiple factors on the mussel mortality risk, and when they had, the effect of no more than three factors was investigated. The exposome is assessed at the individual level by characterising the specific signatures (or profiles) of the effects of previous exposures based on "omics" technologies (Wild, 2012). The exposome complements the genome by providing a comprehensive description of the lifelong exposure history of an individual. On the one hand, the recent use of tissue and molecular biomarkers in mussels M. galloprovincialis has enabled us to distinguish coastal sites according to their pollution level (Carella et al., 2018 ; Matozzo et al., 2018). On the other, the application of "omics" approaches has significantly improved knowledge about the interactions between the Ostreid herpesvirus OsHV-1 and the Pacific oyster Crassostrea gigas (Nguyen et al., 2018). Further application of "omics" technologies should be encouraged to develop and validate sets of biomarkers relevant to multiple exposures in the context of mussel mortality events. However, exposure biomarker approaches should be coupled with refined questionnaire-based approaches to collect husbandry practices and the life history of the mussel population under study, and environmental monitoring at different temporal and geographical scales.

\subsection{Develop tools to assess multi-exposure of mussels on a routine basis}

The fourth recommendation draws attention to the need for tools for mussel exposure assessment. In particular, there is a need to develop screening tools that capture multiple pathogens and pollutants on a routine basis. Effectively, in the literature reviewed, these risk factor topics were often explored using targeted approaches and only a few pathogens or pollutants were simultaneously investigated. Generic methods such as histopathology allow for detection of multiple infections and emerging diseases, but their slowness and low sensitivity for detection of small protistan, viral or bacterial pathogens are not suitable for extensive routine use. Rapid tools such as multiplex DNA-based polymerase chain reaction 
(PCR) and DNA microarray-based assays have low detection limits but require that the specific target pathogens have been identified, which is not appropriate in mortality exploration without prior knowledge of the causative pathogen. Development of microbial metagenomics should be encouraged because such approaches allow simultaneous identification of a large number of pathogen genomes (abundance and diversity) from the same sample at the same time, without prior knowledge of their genomic sequences (Gilbert \& Dupont, 2011). This type of overall approach has the ability to identify coinfections within the host (Yang et al., 2011) and is also applicable to environmental samples (Munang'andu, 2016). The development of high-throughput sequencing (HTS) technologies and bioinformatics tools for nucleic acid sequence assembly and annotation has made it possible to use these approaches in a cost-effective manner, and thus, at a large scale. Although microbial metagenomics is still underused in aquaculture (Martinez-Porchas \& VargasAlbores, 2017), studying mussel mortalities through the metagenomics perspective should be favoured to help understand the involvement of pathogens in mortality outbreaks by comparing the microbial profiles of animals and seawater in sites in which mortality occurs vs. sites with a non-mortality context, or before vs. during the course of mortality events. To go further, as positive results provided by DNA-based methodology are not clearly indicative of actual infection, metatranscriptomics approaches should be preferentially developed, in agreement with the exposome concept detailed above, to identify only active pathogens in a replication state. This would facilitate the biological interpretation of the results and discard environmental DNA or traces that are not relevant to the mortality occurrence. First milestones in that direction have been laid by combining microbiome characterization (16S rRNA HTS) and host-gene expression profiles (RNA-seq) to decipher the factors underlying mass mortality in the stripped venus clam, Chamelea gallina, which suggested potential chemical pollutant-pathogen interactions (Milan et al. 2019). 
Similarly, further work is needed on long-term monitoring of multiple relevant pollutants in marine environments. Data are required to assess the effects of long-term and low-level exposure to multiple contaminants on the mortality risk of mussels. However, progress in in situ sensor technologies is still needed to enable cost-effective and continuous monitoring of contaminants in seawater (Justino et al., 2015). In particular, passive sampling technologies (Schintu et al., 2014) that capture a wide range of environmental pollutants, should enable us to assess the effects of multiple exposures (i.e. a cocktail effect) and of chronic exposure to contaminants on the mortality risk of mussels.

In addition to these previous recommendations, the STC highlights the need to cautiously define the epidemiological units and their appropriate related exposures, as the hierarchical organisation of the system under study should be considered. Future investigators should be warned against the ecological fallacy, i.e. inferring causation at the individual level from population level comparisons, as well as the atomistic fallacy, i.e. inferring causation at the population level from individual level comparisons (Schwartz, 1994 ; Susser, 1973).

\subsection{Assess the impact of husbandry and fishery practices on the mortality risk}

The fifth recommendation pertains to the need for assessment of the impact of husbandry and fishery practices on mussel mortality risk. Although one third of the corpus reviewed investigated the effect of husbandry practices on mussel mortality, these were always controlled field trial studies, i.e. studies in which the investigator controls the allocation of the mussels to the study groups, with or without application of the practice under study. Future research should include long-term monitoring of mussel populations and the multiple exposures, and importantly practices occurring in usual farming or harvesting conditions. 
Observation studies of this kind would involve engaging mussel farmers and fishermen in the study.

\subsection{Co-construct studies with stakeholders}

The last recommendation is the need for co-construction of future large-scale prospective studies on mussel mortality risk factors with stakeholders, specifically mussel farmers and fishermen, to guarantee sustainability and utility of the results. Stakeholders should be engaged as early as possible and throughout the process, in as many of the following phases as possible: knowledge provision, data collection and integration, interpretation of results, and development of mitigating solutions (Reed, 2008).

Addressing the STC recommendations implies the need for interdisciplinary research. Conducting large-scale eco-epidemiological analyses of multiple exposures associated with mussel mortality, including the different organisation levels of the system under study, would require increased collaboration between epidemiologists, biostatisticians, and experts in bioinformatics and biotechnologies, as well as laboratory, environmental and social scientists. Processing and analysing large datasets generated and collected at different scales would also require adapted capabilities for the management and analysis of large data flows. The STC panel, by gathering scientists from different research disciplines, the shellfish industry, and government authorities, represents a first step in this interdisciplinary process. This configuration made it possible to build over-arching recommendations that highlight multidisciplinary research needs.

The STC also recognised that, although assessing all risk factors of mussel mortality within a large- scale survey would be ideal, it is not realistically achievable at this time. By their 
nature, prospective cohort studies take time as well as funding. The cost of equipment and technologies needed may be high, and therefore their application to population-based studies may also be costly. This type of project would require an enormous effort for general coordination, for the supervision of the participating mussel farmers and fishermen, and for the maintenance of a central database. These recommendations also involve a significant financial contribution and may not always be immediately feasible as innovative tools and developments are needed, e.g. for improved measurement of multiple exposures at different time points of the production cycle of mussels. Thus, given the very high costs of such studies and the complexity of putative risk factors in mussel mortality, even a partial understanding of a sub-set of exposures could provide substantial advances in understanding mussel mortality determinants. There could be further efforts to coordinate a major national prospective cohort study, supported by coordinated national investment with regional funders, able to target their contribution to exposures of regional priority. Data generated should be shared in a common and publicly available database among stakeholders, to facilitate cooperation. Overall, standardising the efforts and developing cooperative initiatives would facilitate comparisons between studies to increase the robustness of data if meta-analyses are required.

\section{Acknowledgements}

This study was commissioned by the French Ministry in charge of Agriculture. The STC warmly thanks Morgane Le Gall from Bibliothèque La Pérouse for all her assistance in adapting the equations to the different search engines used to identify studies and in conducting the database searches. The STC also thanks all the bodies and institutions that made their agents available as experts for the panel. 


\section{References}

Ajjabi LC, Abaab M, Segni R (2018) The red macroalga Gracilaria verrucosa in co-culture with the Mediterranean mussels Mytilus galloprovincialis: productivity and nutrient removal performance. Aquaculture International 26: 253-266.

Akaishi FM, St-Jean SD, Bishay F, Clarke J, Rabitto ID, Ribeiro CAD (2007) Immunological responses, histopathological finding and disease resistance of blue mussel (Mytilus edulis) exposed to treated and untreated municipal wastewater. Aquatic Toxicology 82: $1-14$.

Alexander AC, Luiker E, Finley M, Culp JM (2016) Mesocosm and field toxicity testing in the marine context. (ed.) Marine ecotoxicology: Current knowledge and future issues, pp. 239-256. Academic Press.

Ali M, Taylor A (2010) The effect of salinity and temperature on the uptake of cadmium and zinc by the common blue mussel, Mytilus edulis, with some notes on their survival. Mesopotamian Journal of Marine Science 25: 11-30.

Allen M (2017) Vote Counting Literature Review Methods. (ed.) The SAGE Encyclopedia of Communication Research Methods, SAGE Publications, Inc Thousand Oaks, CA.

Altieri AH, Witman JD (2006) Local extinction of a foundation species in a hypoxic estuary: integrating individuals to ecosystem. Ecology 87: 717-730.

Anestis A, Lazou A, Portner HO, Michaelidis B (2007) Behavioral, metabolic, and molecular stress responses of marine bivalve Mytilus galloprovincialis during long-term acclimation at increasing ambient temperature. American Journal of PhysiologyRegulatory Integrative and Comparative Physiology 293: R911-R921. 
Anestis A, Portner HO, Michaelidis B (2010) Anaerobic metabolic patterns related to stress responses in hypoxia exposed mussels Mytilus galloprovincialis. Journal of Experimental Marine Biology and Ecology 394: 123-133.

Anon (2016) Termes de référence pour le coordinateur national de la stratégie sanitaire et zoosanitaire en conchyliculture et pêche de coquillages. Ref. 1602021. Direction Générale de l'Alimentation, Service des actions sanitaires en production primaire, Sous-direction de la santé et de la protection animales, Bureau de la Santé Animale.

Anon (2018) Instruction technique DGAL/SASPP/2018-444 relative à la surveillance des mortalités massives aiguës d'abeilles adultes avec hypothèse d'intoxication par des produits et pratiques phytopharmaceutiques, biocides et médicamenteuses.

Aypa SM (1990) Mussel culture. Regional Seafarming Development and Demonstrating Project (RAS), Selected papers on mollusc culture, UNDP/FAO (RAS/90/002), National Inland Fisheries Institute, Kasetsart University Campus Bangkhen, Bangkok. Babarro JMF, De Zwaan A (2008) Anaerobic survival potential of four bivalves from different habitats. A comparative survey. Comparative Biochemistry and Physiology a-Molecular \& Integrative Physiology 151: 108-113.

Barrento S, Powell A (2016) The effect of transportation and re-watering strategies on the survival, physiology and batch weight of the blue mussel, Mytilus edulis. Aquaculture 450: 194-198.

Barrio Frojan CRS, Boyd SE, Cooper KM, Eggleton JD, Ware S (2008) Long-term benthic responses to sustained disturbance by aggregate extraction in an area off the east coast of the United Kingdom. Estuarine Coastal and Shelf Science 79: 204-212.

Benabdelmouna A, Ledu C (2016) The mass mortality of blue mussels (Mytilus spp.) from the Atlantic coast of France is associated with heavy genomic abnormalities as evidenced by flow cytometry. Journal of Invertebrate Pathology 138: 30-38. 
Benabdelmouna A, Garcia C, Ledu C, Lamy P, Maurouard E, Degremont L (2018) Mortality investigation of Mytilus edulis and Mytilus galloprovincialis in France: An experimental survey under laboratory conditions. Aquaculture 495: 831-841.

Bernard I, Allain G (2016) Les mortalités de moules en 2014 et 2015 vues par les professionnels - Compte-rendu de la phase 1 : synthèse sur l'émergence, la propagation et l'installation des mortalités. Rapport technique CRC Bretagne Nord, pp. 28.

Bernard I, Charles M, Allain G, Burioli EAV, Villalba A, Le Foll F, et al. (2018a) Bilan de l'observatoire des mortalités de moules en Bretagne Nord pour la saison 2016-2017 et premiers éléments sur les organismes pathogènes présents. Rapport technique CRC Bretagne Nord, pp. 26.

Bernard I, Charles M, Allain G, Burioli EAV, Villalba A, Le Foll F, et al. (2018b) Recherche de pathogènes en lien avec les mortalités de moules en Bretagne Nord en 2017 et 2018 - rapport final. Rapport technique CRC Bretagne Nord, pp. 26.

Bertolini C, Montgomery WI, O'Connor NE (2018) Habitat with small inter-structural spaces promotes mussel survival and reef generation. Marine Biology 165.

Binzer SB, Lundgreen RBC, Berge T, Hansen PJ, Vismann B (2018) The blue mussel Mytilus edulis is vulnerable to the toxic dinoflagellate Karlodinium armiger-Adult filtration is inhibited and several life stages killed. Plos One 13.

Bownes SJ, McQuaid CD (2010) Mechanisms of habitat segregation between an invasive (Mytilus galloprovincialis) and an indigenous (Perna perna) mussel: adult growth and mortality. Marine Biology 157: 1799-1810.

Bressan M, Chinellato A, Munari M, Matozzo V, Manci A, Marceta T, et al. (2014) Does seawater acidification affect survival, growth and shell integrity in bivalve juveniles? Marine Environmental Research 99: 136-148. 
Brousscau DJ, Goldberg R, Garza C (2014) Impact of Predation by the Invasive Crab Hemigrapsus sanguineus on Survival of Juvenile Blue Mussels in Western Long Island Sound. Northeastern Naturalist 21: 119-133.

Burge CA, Eakin CM, Friedman CS, Froelich B, Hershberger PK, Hofmann EE, et al. (2014) Climate Change Influences on Marine Infectious Diseases: Implications for Management and Society. In: Carlson CA, Giovannoni SJ (ed.) Annual Review of Marine Science, Vol 6, pp. 249-277.

Carella F, Sardo A, Mangoni O, Di Cioccio D, Urciuolo G, De Vico G, et al. (2015) Quantitative histopathology of the Mediterranean mussel (Mytilus galloprovincialis L.) exposed to the harmful dinoflagellate Ostreopsis cf. ovata. Journal of Invertebrate Pathology 127: 130-140.

Carella F, Aceto S, Mangoni O, Mollica MP, Cavaliere G, Trinchese G, et al. (2018) Assessment of the Health Status of Mussels Mytilus galloprovincialis Along the Campania Coastal Areas: A Multidisciplinary Approach. Frontiers in Physiology 9.

Chauzat M-P, Laurent M, Rivière M-P, Saugeon C, Hendrickx P, M. R-C (2016) EPILOBEE. A pan-European epidemiological study on honeybee colony losses 2012-2014. pp. 44.

Christensen HT, Dolmer P, Petersen JK, Torring D (2012) Comparative study of predatory responses in blue mussels (Mytilus edulis L.) produced in suspended long line cultures or collected from natural bottom mussel beds. Helgoland Marine Research 66: 1-9.

Clements JC, Hicks C, Tremblay R, Comeau LA (2018) Elevated seawater temperature, not pCO(2), negatively affects post-spawning adult mussels (Mytilus edulis) under food limitation. Conservation Physiology doi: 10.1093/conphys/cox078.

Cottrell RS, Black KD, Hutchison ZL, Last KS (2016) The Influence of Organic Material and Temperature on the Burial Tolerance of the Blue Mussel, Mytilus edulis: 
Considerations for the Management of Marine Aggregate Dredging. Plos One doi: 10.1371/journal.pone.0147534.

Culp JM, Yates AG, Armanini DG, Bairds DJ (2017) Establishing cause-effect relationships in multi-stressor environments. In: Hauer F, Lamberti, G.A. (ed.) Methods in Stream Ecology, pp. 335-351. Academic Press, Burlington, MA, USA.

Danellakis D, Ntaikou I, Kornaros M, Dailianis S (2011) Olive oil mill wastewater toxicity in the marine environment: Alterations of stress indices in tissues of mussel Mytilus galloprovincialis. Aquatic Toxicology 101: 358-366.

Dionne M, Lauzon-Guay JS, Hamilton DJ, Barbeau MA (2006) Protective socking material for cultivated mussels: a potential non-disruptive deterrent to reduce losses to diving ducks. Aquaculture International 14: 595-613.

Dowd WW, Somero GN (2013) Behavior and survival of Mytilus congeners following episodes of elevated body temperature in air and seawater. Journal of Experimental Biology 216: 502-514.

Eggermont M, Tamanji A, Nevejan N, Bossier P, Sorgeloos P, Defoirdt T (2014) Stimulation of heterotrophic bacteria associated with wild-caught blue mussel (Mytilus edulis) adults results in mass mortality. Aquaculture 431: 136-138.

Eggermont M, Bossier P, Pande GSJ, Delahaut V, Rayhan AM, Gupta N, et al. (2017) Isolation of Vibrionaceae from wild blue mussel (Mytilus edulis) adults and their impact on blue mussel larviculture. Fems Microbiology Ecology doi: 10.1093/femsec/fix039.

EU Copernicus Marine Service Information (2019) Ocean monitoring indicators. http://marine.copernicus.eu/science-learning/ocean-monitoring-indicators/catalogue/. Accessed on 04 June 2019. 
European Food Safety Agency (2010) Application of systematic review methodology to food and feed safety assessments to support decision making. EFSA Journal 8: 1637.

FAO (2019) FAO yearbook. Fishery and Aquaculture Statistics 2017/FAO annuaire. Statistiques des pêches et de l'aquaculture 2017/FAO anuario. Estadísticas de pesca y acuicultura 2017 Rome/Roma.

Fuentes J, Reyero I, Zapata C, Alvarez G (1992) Influence of Stock and Culture Site on Growth-Rate and Mortality of Mussels (Mytilus galloprovincialis Lmk) in Galicia, Spain. Aquaculture 105: 131-142.

Fuentes J, Reyero I, Zapata C, Alvarez G (1994) Production Traits of the Mussel Mytilus galloprovincialis Cultured in Galicia (Nw of Spain) - Relative Effects of Source of Seed and Growing Environment. Aquaculture 122: 19-31.

Fuentes J, Lopez JL, Mosquera E, Vazquez J, Villalba A, Alvarez G (2002) Growth, mortality, pathological conditions and protein expression of Mytilus edulis and $M$. galloprovincialis crosses cultured in the Ria de Arousa (NW of Spain). Aquaculture 213: $233-251$.

Gammoudi M, Ben Ahmed R, Bouriga N, Ben-Attia M, Harrath AH (2017) Predation by the polyclad flatworm Imogine mediterranea on the cultivated mussel Mytilus galloprovincialis in Bizerta Lagoon (northern Tunisia). Aquaculture Research 48: $1608-1617$.

Garcia C, Lupo C, Travers MA, Arzul I, Tourbiez D, Haffner P, et al. (2014) Vibrio aestuarianus and Pacific oyster in France: a review of 10 years of surveillance. In: National Shellfisheries Association 106th Annual Meeting, Jacksonville, United States. 
Garcia C, Francois C, Lupo C, Arzul I, Chollet B, Dubreuil C, et al. (2015) Epidemiologic Al report 2014 France. In: Annual Meeting of the National Reference Laboratories for Mollusc Diseases, Saintes, France.

Garcia C, Haond C, Chollet B, Nerac M, Omnes E, Joly JP, et al. (2018) Descriptions of Mikrocytos veneroides $\mathrm{n}$. sp and Mikrocytos donaxi n. sp (Ascetosporea: Mikrocytida: Mikrocytiidae), detected during important mortality events of the wedge clam Donax trunculus Linnaeus (Veneroida: Donacidae), in France between 2008 and 2011. Parasites \& Vectors doi: 10.1186/S13071-018-2692-0.

Garcia C, Tourbiez D, Dubreuil C, Serpin D, Mesnil A, Goncalves De Sa A, et al. (2019) Characterization of Vibrio aestuarianus detected in cockles. In: Annual Meeting \& workshop of the National Reference Laboratories for Mollusc Diseases and COCLES project, Arcachon, France.

Gardner JPA, Thompson RJ (2001) The effects of coastal and estuarine conditions on the physiology and survivorship of the mussels Mytilus edulis, M. trossulus and their hybrids. Journal of Experimental Marine Biology and Ecology 265: 119-140.

Gardner JPA (2013) Bottom-up control of temperate rocky intertidal community structure: evidence from a transplant experiment. Marine Ecology Progress Series 491: 137-151.

Gazeau F, Alliouane S, Bock C, Bramanti L, Lopez Correa M, Gentile M, et al. (2018) Impact of ocean acidification and warming on the Mediterranean mussel (Mytilus galloprovincialis). Frontiers in Marine Science doi: 10.3389/fmars.2014.00062.

Gestoso I, Arenas F, Olabarria C (2016) Ecological interactions modulate responses of two intertidal mussel species to changes in temperature and $\mathrm{pH}$. Journal of Experimental Marine Biology and Ecology 474: 116-125.

Gilbert JA, Dupont CL (2011) Microbial Metagenomics: Beyond the Genome. Annual Review of Marine Science, Vol 3 3: 347-371. 
Glize P, Brouard L, Gérard S, Meneur C (2017) Suivi de la mortalité de populations de moules en Pays de Loire : Programme TESCOR. SMIDAP \& CRC Pays de la Loire, pp. 25.

Glize P, Gourmelen G (2018) Suivi de la mortalité de populations de moules en Pays de Loire : Programme TESCOR 2. SMIDAP \& CRC Pays de la Loire, pp. 33.

Greenacre MJ (1984) Theory and Applications of Correspondence Analysis, London.

Guillotreau P, Allison EH, Bundy A, Cooley SR, Defeo O, Le Bihan V, et al. (2017) A comparative appraisal of the resilience of marine social-ecological systems to mass mortalities of bivalves. Ecology and Society doi: 10.5751/Es-09084-220146.

Gvozdenovic S, Mandic M, Pesic V, Nikolic M, Pesic A, Ikica Z (2017) Comparison between IMTA and monoculture farming of mussels (Mytilus galloprovincialis L.) in the Boka Kotorska Bay. Acta Adriatica 58: 271-284.

Hamer B, Jaksic Z, Pavicic-Hamer D, Peric L, Medakovic D, Ivankovic D, et al. (2008) Effect of hypoosmotic stress by low salinity acclimation of Mediterranean mussels Mytilus galloprovincialis on biological parameters used for pollution assessment. Aquatic Toxicology 89: 137-151.

Hiebenthal C, Philipp EER, Eisenhauer A, Whal M (2013) Effects of seawater pCO2 and temperature on shell growth, shell stability, condition and cellular stress of Western Baltic Sea Mytilus edulis (L.) and Arctica islandica (L.). Marine Biology 160: 20732087.

Hutchison ZL, Hendrick VJ, Burrows MT, Wilson B, Last KS (2016) Buried Alive: The Behavioural Response of the Mussels, Modiolus modiolus and Mytilus edulis to Sudden Burial by Sediment. Plos One doi: 10.1371/journal.pone.0151471. 
Incze LS, Lutz RA, Watling L (1980) Relationships between Effects of EnvironmentalTemperature and Seston on Growth and Mortality of Mytilus edulis in a Temperate Northern Estuary. Marine Biology 57: 147-156.

INERIS (2019) Portail Substances Chimiques. https://substances.ineris.fr/fr/. Accessed on 05 september 2019.

IPCC (Intergovernmental Panel on Climate Change) (2019) Summary for Policymakers. In: H.O. Pörtner DCR, V. Masson-Delmotte, P. Zhai, M. Tignor, E. Poloczanska, K. Mintenbeck, M. Nicolai, A. Okem, J. Petzold, B. Rama, N. Weyer (ed.) IPCC Special Report on the Ocean and Cryosphere in a Changing Climate, pp. 1170.

Jones SJ, Mieszkowska N, Wethey DS (2009) Linking Thermal Tolerances and Biogeography: Mytilus edulis (L.) at its Southern Limit on the East Coast of the United States. Biological Bulletin 217: 73-85.

Jones SJ, Lima FP, Wethey DS (2010) Rising environmental temperatures and biogeography: poleward range contraction of the blue mussel, Mytilus edulis L., in the western Atlantic. Journal of Biogeography 37: 2243-2259.

Justino CIL, Freitas AC, Duarte AC, Santos TAPR (2015) Sensors and biosensors for monitoring marine contaminants. Trends in Environmental Analytical Chemistry 6-7: 21-30.

Karayucel S, Karayucel I (2000) The effect of environmental factors, depth and position on the growth and mortality of raft-cultured blue mussels (Mytilus edulis L.). Aquaculture Research 31: 893-899.

Kassambra A, Mundt F (2017) Extract and Vizualize the Results of Multivariate Data Analyses. https://CRAN.R-project.org/package=factoextra 
Kovacic I, Pavicic-Hamer D, Kanduc T, Hamer B (2017) Adaptation of cultured mussel Mytilus galloprovincialis Lamarck, 1819 from the northern Adriatic Sea to nearby aquaculture sites and translocation. Acta Adriatica 58: 285-296.

Lajeunesse MJ (2016) Facilitating systematic reviews, data extraction, and meta-analysis with the metagear package for R. Methods in Ecology and Evolution 7: 323-330.

Landis JR, Koch GG (1977) Measurement of Observer Agreement for Categorical Data. Biometrics 33: 159-174.

Lauzon-Guay JS, Dionne M, Barbeau MA, Hamilton DJ (2005) Effects of seed size and density on growth, tissue-to-shell ratio and survival of cultivated mussels (Mytilus edulis) in Prince Edward Island, Canada. Aquaculture 250: 652-665.

Lê S, Josse J, Husson F (2008) FactoMineR: An R Package for Multivariate Analysis. Journal of Statistical Software 25: 1-18.

LeBlanc N, Tremblay R, Davidson J, Landry T, McNiven M (2008) The effect of selection treatments on Mytilus edulis, modifications of genetic and physiological characteristics. Marine Biology 153: 1141-1152.

Lenz M, Ahmed Y, Canning-Clode J, Diaz E, Eichhorn S, Fabritzek AG, et al. (2018) Heat challenges can enhance population tolerance to thermal stress in mussels: a potential mechanism by which ship transport can increase species invasiveness. Biological Invasions 20: 3107-3122.

Li JJ, Schiavo S, Dong XL, Rametta G, Miglietta ML, Oliviero M, et al. (2018) Early ecotoxic effects of $\mathrm{ZnO}$ nanoparticle chronic exposure in Mytilus galloprovincialis revealed by transcription of apoptosis and antioxidant-related genes. Ecotoxicology 27: $369-384$. 
Lok A, Acarli S, Serdar S, Kose A, Yildiz H (2007) Growth and mortality of Mediterranean mussel Mytilus galloprovincialis Lam., 1819, in relation to size on longline in Mersin Bay, Izmir (Turkey-Aegean Sea). Aquaculture Research 38: 819-826.

Lowen JB (2008) To grow and survive or reproduce and die? Life-history strategies and ecological interactions between the mussels Mytilus edulis (Linneaus, 1758) and Mytilus trossulus (Gould, 1850) in the northwest Atlantic. Dissertation Abstracts International 71: 152.

Lupo C, François C, Arzul I, Garcia C, Joly JP, Renault T (2012) Challenges related to disease surveillance in marine shellfish in France. Epidémiologie et Santé Animale 62: $27-42$.

Lupo C, Prou J (2016) Enhanced surveillance of shellfish mortality to improve early detection and investigation of outbreaks of exotic or emerging infectious diseases: An example of a mass mortality outbreak of mussels, France 2014. Preventive Veterinary Medicine 132: 57-66.

Mallet AL, Carver CEA, Coffen SS, Freeman KR (1987) Mortality Variations in NaturalPopulations of the Blue Mussel, Mytilus edulis. Canadian Journal of Fisheries and Aquatic Sciences 44: 1589-1594.

Mallet AL, Carver CEA, Freeman KR (1990) Summer Mortality of the Blue Mussel in Eastern Canada - Spatial, Temporal, Stock and Age Variation. Marine Ecology Progress Series 67: 35-41.

Marquet N, Nicastro KR, Gektidis M, McQuaid CD, Pearson GA, Serrao EA, et al. (2013) Comparison of phototrophic shell-degrading endoliths in invasive and native populations of the intertidal mussel Mytilus galloprovincialis. Biological Invasions 15: 1253-1272. 
Martin SW, Meek AH, Willeberg P (1987) Veterinary Epidemiology, Principles and Methods, Ames: Iowa State University Press, 343 p.

Martinez-Porchas M, Vargas-Albores F (2017) Microbial metagenomics in aquaculture: a potential tool for a deeper insight into the activity. Reviews in Aquaculture 9: 42-56.

Matozzo V, Ercolini C, Serracca L, Battistini R, Rossini I, Granato G, et al. (2018) Assessing the health status of farmed mussels (Mytilus galloprovincialis) through histological, microbiological and biomarker analyses. Journal of Invertebrate Pathology 153: 165179.

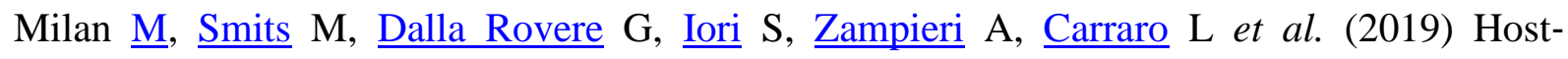
microbiota interactions shed light on mortality events in the striped venus clam Chamelea gallina. Molecular Ecology doi.org/10.1111/mec.15227.

Miller RG, Hutchison ZL, Macleod AK, Burrows MT, Cook EJ, Last KS, et al. (2013) Marine renewable energy development: assessing the Benthic Footprint at multiple scales. Frontiers in Ecology and the Environment 11: 433-440.

Miossec L, Allain G, Arzul I, François C, Garcia C, Cameron A (2009) First results of an epidemiological study on oyster (Crassostrea gigas) mortality events in France during summer 2008. In: Proceedings of the 12th International Symposium on Veterinary Epidemiology and Economics, South Africa, Durban.

Moher D, Liberati A, Tetzlaff J, Altman DG, Grp P (2009) Preferred reporting items for systematic reviews and meta-analyses: the PRISMA statement. Bmj-British Medical Journal doi: 10.1136/Bmj.B2535.

Moschino V, Del Negro P, De Vittor C, Da Ros L (2016) Biomonitoring of a polluted coastal area (Bay of Muggia, Northern Adriatic Sea): A five-year study using transplanted mussels. Ecotoxicology and Environmental Safety 128: 1-10. 
Moschino V, Schintu M, Marrucci A, Marras B, Nesto N, Da Rosa L (2017) An ecotoxicological approach to evaluate the effects of tourism impacts in the Marine Protected Area of La Maddalena (Sardinia, Italy). Marine Pollution Bulletin 122: 306315.

Munang'andu HM (2016) Environmental Viral Metagenomics Analyses in Aquaculture: Applications in Epidemiology and Disease Control. Frontiers in Microbiology doi: 10.3389/Fmicb.2016.01986.

Myrand B, Gaudreault J (1995) Summer mortality of blue mussels (Mytilus edulis Linneaus, 1758) in the Magdalen Islands (southern Gulf of St Lawrence, Canada). Journal of Shellfish Research 14: 395-404.

Myrand B, Guderley H, Himmelman JH (2000) Reproduction and summer mortality of blue mussels Mytilus edulis in the Magdalen Islands, southern Gulf of St. Lawrence. Marine Ecology Progress Series 197: 193-207.

Nguyen TV, Alfaro AC, Merien F (2018) Omics approaches to investigate host-pathogen interactions in mass mortality outbreaks of Crassostrea gigas. Reviews in Aquaculture.

Nicastro KH, McQuaid CD, Zardi GI (2018) Between a rock and a hard place: combined effect of trampling and phototrophic shell-degrading endoliths in marine intertidal mussels. Marine Biodiversity doi: 10.1007/s12526-018-0924-3.

Nicastro KR, Zardi GI, McQuaid CD (2008) Movement behaviour and mortality in invasive and indigenous mussels: resilience and resistance strategies at different spatial scales. Marine Ecology Progress Series 372: 119-126.

Nicastro KR, Zardi GI, McQuaid CD (2010) Differential reproductive investment, attachment strength and mortality of invasive and indigenous mussels across heterogeneous environments. Biological Invasions 12: 2165-2177. 
O'Connor NE (2010) Shore exposure affects mussel population structure and mediates the effect of epibiotic algae on mussel survival in SW Ireland. Estuarine Coastal and Shelf Science 87: 83-91.

Olabarrial C, Gestoso I, Lima FP, Vazquez E, Comeau LA, Gomes F, et al. (2016) Response of Two Mytilids to a Heatwave: The Complex Interplay of Physiology, Behaviour and Ecological Interactions. Plos One doi: 10.1371/journal.pone.0164330.

Oliveira P, Almeida A, Calisto V, Esteves VI, Schneider RJ, Wrona FJ, et al. (2017) Physiological and biochemical alterations induced in the mussel Mytilus galloprovincialis after short and long-term exposure to carbamazepine. Water Research 117: 102-114.

Paetzold SC, Davidson J (2011) Aquaculture fouling: Efficacy of potassium monopersulphonate triple salt based disinfectant (Virkon(R) Aquatic) against Ciona intestinalis. Biofouling 27: 655-665.

Peden R, Rocher B, Chan P, Vaudry D, Poret A, Olivier S, et al. (2018) Highly polluted life history and acute heat stress, a hazardous mix for blue mussels. Marine Pollution Bulletin 135: 594-606.

Peeler EJ, Taylor NGH (2011) The application of epidemiology in aquatic animal health opportunities and challenges. Veterinary Research 42: 94.

Penney RW, Hart MJ, Templeman ND (2006) Genotype-dependent survival, growth, and production in cultured blue mussels, Mytilus spp.: Results of a reciprocal seed transfer experiment. Journal of Shellfish Research 25: 515-525.

Pépin JF, Benabdelmouna A, Bierne N, Bouget JF, Chabirand JM, Costes L, et al. (2017) Mortalités de moules bleues dans les secteurs mytilicoles charentais et vendéens : description et facteurs liés -MORBLEU-. R.INT.RBE/SG2M-LGPMM. https://archimer.ifremer.fr/doc/00391/50288/. 
Pépin JF, Benabdelmouna A, Bierne N, Bouget JF, Chabirand JM, Costes L, et al. (2018) Mortalités de moules bleues dans les secteurs mytilicoles : description et facteurs liés MORBLEU. R.INT.RBE/SG2M-LGPMM. .

Petraitis PS (1998) Timing of mussel mortality and predator activity in sheltered bays of the Gulf of Maine, USA. Journal of Experimental Marine Biology and Ecology 231: 4762.

Plass-Johnson JG, McQuaid CD, Porri F (2010) Top-down effects on intertidal mussel populations: assessing two predator guilds in a South African marine protected area. Marine Ecology Progress Series 411: 149-159.

R Core Team (2019) R: A language and environment for statistical computing. R Foundation for Statistical Computing, Vienna, Austria.

Ramon M, Fernandez M, Galimany E (2007) Development of mussel (Mytilus galloprovincialis) seed from two different origins in a semi-enclosed Mediterranean Bay (NE Spain). Aquaculture 264: 148-159.

Reed M (2008) Stakeholder participation for environmental management: A literature review. Biological Conservation 141: 2417-2431.

Romero A, Costa MD, Forn-Cuni G, Balseiro P, Chamorro R, Dios S, et al. (2014) Occurrence, seasonality and infectivity of Vibrio strains in natural populations of mussels Mytilus galloprovincialis. Diseases of Aquatic Organisms 108: 149-163.

Rosen G, Lotufo GR (2007) Toxicity of explosive compounds to the marine mussel, Mytilus galloprovincialis, in aqueous exposures. Ecotoxicology and Environmental Safety 68: 228-236.

Sargeant JM, O'Connor AM, Dohoo IR, Erb HN, Cevallos M, Egger M, et al. (2016) Methods and processes of developing the strengthening the reporting of observational studies in 
epidemiology - veterinary (STROBE-Vet) statement. Preventive Veterinary Medicine 134: 188-196.

Schintu M, Marrucci A, Marras B (2014) Passive Sampling Technologies for the Monitoring of Organic and Inorganic Contaminants in Seawater. In: Cao G, Orrù, R., (ed.) Current Environmental Issues and Challenges, pp. 214-237. Springer, Dordrecht.

Schneider KR (2008) Heat Stress in the Intertidal: Comparing Survival and Growth of an Invasive and Native Mussel Under a Variety of Thermal Conditions. Biological Bulletin 215: 253-264.

Schwartz S (1994) The Fallacy of the Ecological Fallacy - the Potential Misuse of a Concept and the Consequences. American Journal of Public Health 84: 819-824.

Sherman BH (2000) Marine ecosystem health as an expression of morbidity, mortality and disease events. Marine Pollution Bulletin 41: 232-254.

Shields JL, Barnes P, Heath DD (2008) Growth and survival differences among native, introduced and hybrid blue mussels (Mytilus spp.): genotype, environment and interaction effects. Marine Biology 154: 919-928.

SMIDAP (2016) Suivi du captage et de la mortalité mytilicoles - CAPEMOULES 1. SMIDAP \& CRC Pays de la Loire.

SMIDAP (2016-2017) Suivi de la mortalité mytilicole - CAPEMOULES 2. SMIDAP \& CRC Pays de la Loire.

Stevens AM, Gobler CJ (2018) Interactive effects of acidification, hypoxia, and thermal stress on growth, respiration, and survival of four North Atlantic bivalves. Marine Ecology Progress Series 604: 143-161.

Stirling HP, Okumus I (1994) Growth, Mortality and Shell Morphology of Cultivated Mussel (Mytilus edulis) Stocks Cross Planted between 2 Scottish Sea Lochs. Marine Biology 119: $115-123$. 
Sun TL, Tang XX, Zhou B, Wang Y (2016) Comparative studies on the effects of seawater acidification caused by $\mathrm{CO} 2$ and $\mathrm{HCl}$ enrichment on physiological changes in Mytilus edulis. Chemosphere 144: 2368-2376.

Suni S, Koskinen K, Kauppi S, Hannula E, Ryynanen T, Aalto A, et al. (2007) Removal by sorption and in situ biodegradation of oil spills limits damage to marine biota: A laboratory simulation. Ambio 36: 173-179.

Susser M (1973) Causal thinking in the health sciences: concepts and strategies of epidemiology, Oxford University Press, Toronto.

Susser M, Susser E (1996) Choosing a future for epidemiology: II. From black box to Chinese boxes and eco-epidemiology. American Journal of Public Health 86: 674-677.

Theodorou JA, Leech BS, Perdikaris C, Hellio C (2017) Summer Re-immersion handling of the mediterranean mussels. In: Proceedings of the Thirteenth International MEDCOAST Congress on Coastal and MArine Sciences, Engeneering, Management and Conservation - MEDCOAST 2017 (ed Öshan E), Mellieha, Malta, pp. 363-368.

Travers MA, Pepin J-F, Soletchnik P, Guesdon S, Le Moine O (2016) Mortalités de moules bleues dans les Pertuis Charentais: description et facteurs liés - MORBLEU. R.INT.RBE/SG2M-LGPMM. https://archimer.ifremer.fr/doc/00324/43539/.

Tremblay R, Myrand B, Sevigny JM, Blier P, Guderley H (1998) Bioenergetic and genetic parameters in relation to susceptibility of blue mussels, Mytilus edulis (L.) to summer mortality. Journal of Experimental Marine Biology and Ecology 221: 27-58.

Tsarpali V, Dailianis S (2012) Investigation of landfill leachate toxic potency: An integrated approach with the use of stress indices in tissues of mussels. Aquatic Toxicology 124: $58-65$.

Tsarpali V, Belavgeni A, Dailianis S (2015) Investigation of toxic effects of imidazolium ionic liquids, [bmim][BF4] and [omim][BF4], on marine mussel Mytilus 
galloprovincialis with or without the presence of conventional solvents, such as acetone. Aquatic Toxicology 164: 72-80.

Tsuchiya M (1983) Mass Mortality in a Population of the Mussel Mytilus edulis-L Caused by High-Temperature on Rocky Shores. Journal of Experimental Marine Biology and Ecology 66: 101-111.

Vickerson A (2009) Managing the health of mussel (Mytilus spp.) seed from Newfoundland: The effects of thermal stressors, transport times, storage conditions and anti-biofouling treatments on the short-term and long-term performance of mussel seed. Masters Abstracts International 48: 114.

Wang J, Ren RM, Yao CL (2018) Oxidative stress responses of Mytilus galloprovincialis to acute cold and heat during air exposure. Journal of Molluscan Studies 84: 285-292.

Waser AM, Splinter W, van der Meer J (2015) Indirect effects of invasive species affecting the population structure of an ecosystem engineer. Ecosphere doi: 10.1890/Es1400437.1.

Wickham H (2016) ggplot2: Elegant Graphics for Data Analysis. Springer-Verlag New York. Wild CP (2005) Complementing the genome with an "exposome": The outstanding challenge of environmental exposure measurement in molecular epidemiology. Cancer Epidemiology Biomarkers \& Prevention 14: 1847-1850.

Wild CP (2012) The exposome: from concept to utility. International Journal of Epidemiology 41: 24-32.

Yang J, Yang F, Ren L, Xiong Z, Wu Z, Dong J, et al. (2011) Unbiased parallel detection of viral pathogens in clinical samples by use of a metagenomic approach. Journal of Clinical Microbiology 49: 3463-3469. 
Zardi GI, Nicastro KR, Porri F, McQuaid CD (2006) Sand stress as a non-determinant of habitat segregation of indigenous (Perna perna) and invasive (Mytilus galloprovincialis) mussels in South Africa. Marine Biology 148: 1031-1038.

Zardi GI, Nicastro KR, McQuaid CD, Erlandsson J (2008) Sand and wave induced mortality in invasive (Mytilus galloprovincialis) and indigenous (Perna perna) mussels. Marine Biology 153: 853-858.

Zardi GI, Nicastro KR, McQuaid CD, Ng TPT, Lathlean J, Seuront L (2016) Enemies with benefits: parasitic endoliths protect mussels against heat stress. Scientific Reports doi: 10.1038/Srep31413. 
Table 1. Characteristics extracted from the studies included in the systematic review of the risk factors for mussel mortality

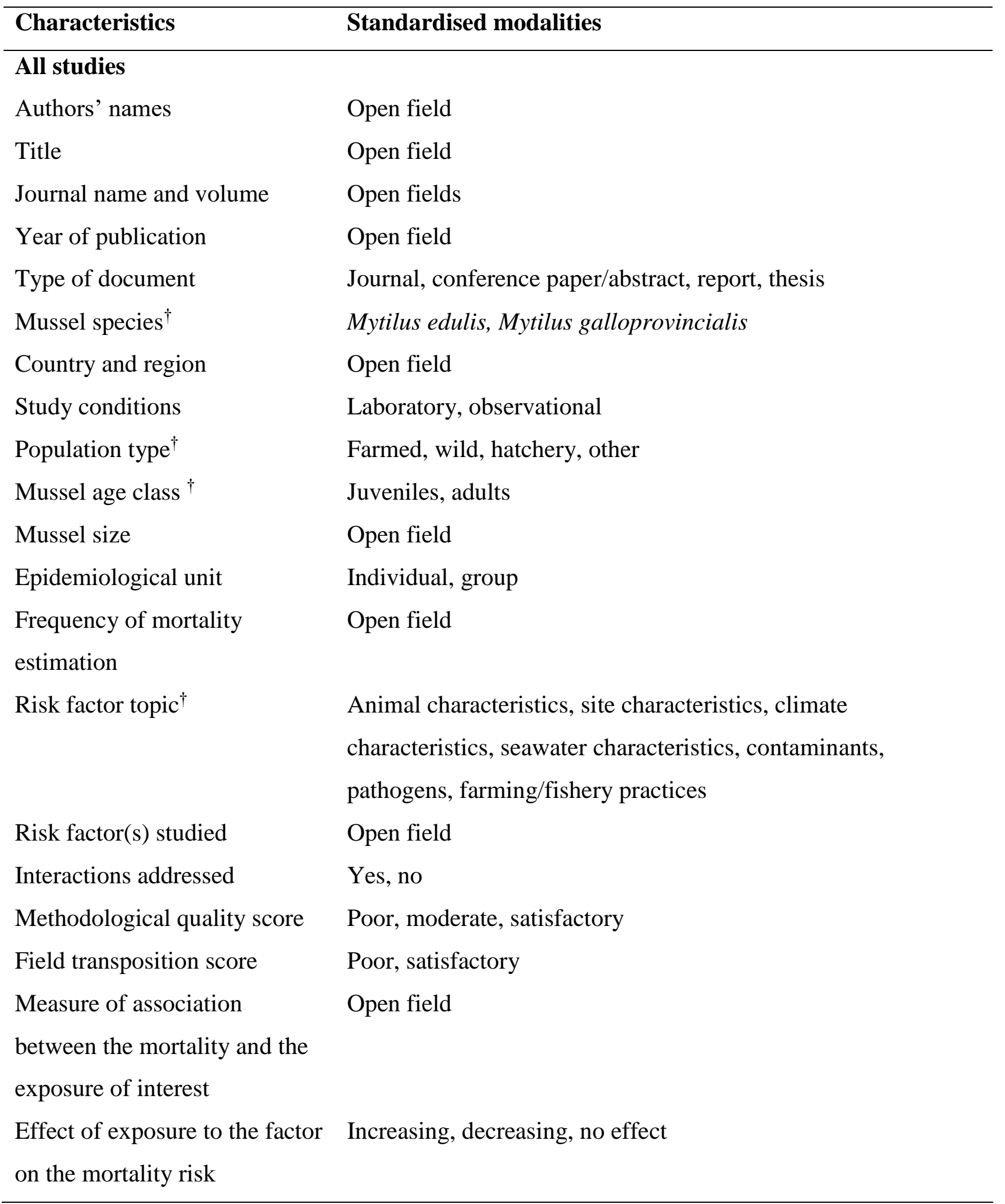

\footnotetext{
${ }^{\dagger}$ Several choices were possible
} 


\section{Observational studies}

Study design

Random sampling

Mortality estimation

Mortality counting method

Laboratory studies

Control presence

Triplicate of the trial

Mortality definition criteria
Cross sectional, case-control, exposed/non exposed cohorts, single prospective cohort

Yes, no

Open field

Open field

Yes, no

Yes, no

Open field 
Table 2. Characteristics and numbers of included studies investigating risk factors of marine mussel mortality $(\mathrm{N}=114)$

\begin{tabular}{ccccccc}
\hline Characteristics & \multicolumn{2}{c}{ M. edulis } & & \multicolumn{2}{c}{ M. galloprovincialis } \\
\cline { 2 - 3 } \cline { 5 - 6 } & Number of & Number of & & Number of & Number of \\
observational & experimental & & observational & experimental \\
studies & studies & & studies & studies \\
$(\mathrm{N}=38)$ & $(\mathrm{N}=28)$ & & $(\mathrm{N}=25)$ & $(\mathrm{N}=23)$
\end{tabular}

Geographic focus

North Sea

3

10

0

1

Black Sea / Mediterranean

0

0

8

11

Atlantic Ocean

Pacific Ocean

31

16

15

9

4

2

2

2

Population type*

Farmed 22

Wild

6

Not reported

20

15

11

0

1

Mussel age class ${ }^{\dagger}$

Juveniles

Adults

Not reported

Mussel size

$<20 \mathrm{~mm}$

20-30 mm

$30-40 \mathrm{~mm}$

$40-50 \mathrm{~mm}$

$50-60 \mathrm{~mm}$

60-70 mm

$>70 \mathrm{~mm}$

Not reported

$\begin{array}{rrrr}4 & 5 & 7 & 2 \\ 6 & 5 & 5 & 4 \\ 5 & 6 & 8 & 4 \\ 4 & 4 & 5 & 3 \\ 3 & 7 & 7 & 8 \\ 2 & 1 & 4 & 1 \\ 1 & 0 & 4 & 2 \\ 22 & 10 & 10 & 1\end{array}$

Epidemiological unit

Individual

Group

0

38
4

24
10

$21 \quad 11$

Study design

\footnotetext{
* Several population types could be examined in a single study; thus, the sum of studies per population type could be greater than the total number of studies

${ }^{\dagger}$ Several age classes could be examined in a single study; thus, the sum of studies per age class can be greater than the total number of studies.
} 
Cross-sectional

Case-control

Exposed/non exposed

cohorts

Single prospective cohort

Strength of proof of causal association provided by the study design

Low

High

\section{Random sampling}

Yes

No

Control presence

Yes

No

Triplicate of the trial

Yes

No

Quality score

Moderate

High

\section{Mortality definition} criteria

Failure to close the valves in response to external stimuli Widely open valves

Not defined

\section{Mortality estimation} methods

Counting

Analysis of digital pictures

of quadrats

Drop-in density of live

mussel

Not reported

\section{Mortality counting}

\section{methods}

Dead and live mussels

Remaining live mussels

Dead mussels

Freshly dead mussels

Empty shells
2

0

10

26

17
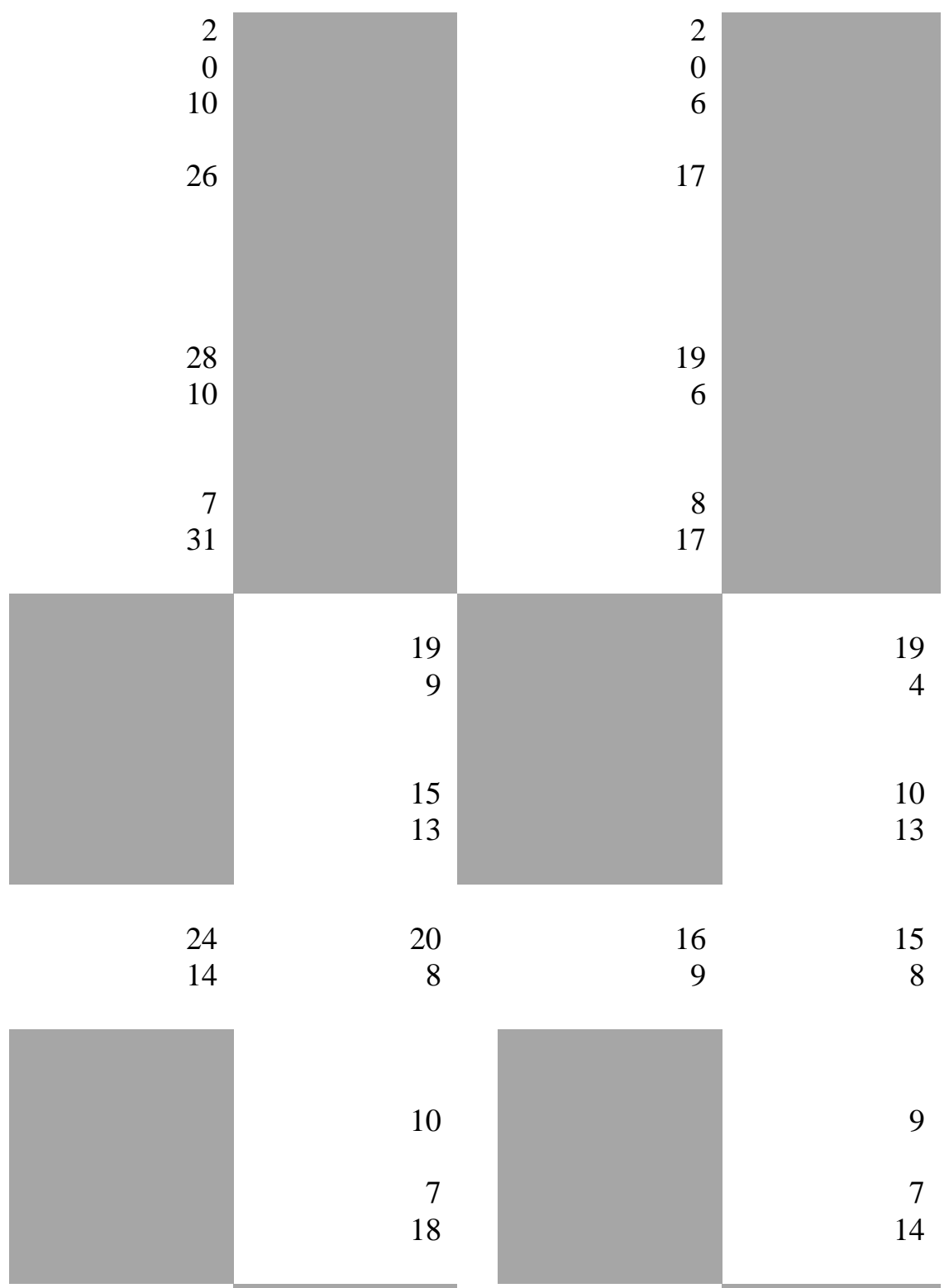

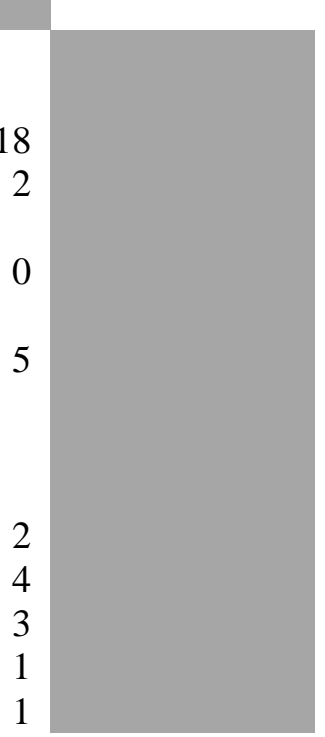

$\$$ Several criteria could be used in a single study; thus, the sum of studies per criterion can be greater than the total number of studies. 
Not reported

Mortality statistics

Final prevalence

Cumulative prevalence

Instantaneous proportion

Half-stock index

Frequency of mortality

\section{estimation $^{\S}$}

Daily

Weekly

Bi-monthly

Monthly

Quarterly

Bi-annually

Annually

At the end of the study

Not reported

\section{Risk factor topics**}

Pathogens

Animal characteristics

Seawater characteristics

Site characteristics

Farming or fishery practices

Contaminants

Climate characteristics
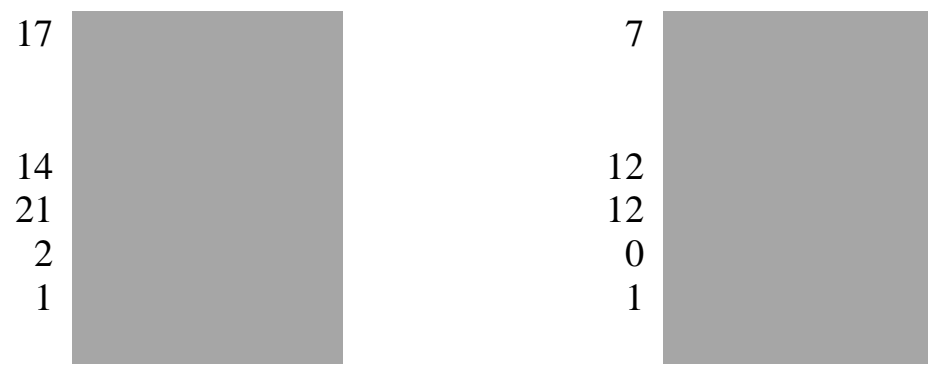

2

9

2

10

33

5

15

5

1

0

5

12

$\begin{array}{rl}1 & 3 \\ 0 & 0 \\ 11 & 3 \\ 5 & 0 \\ 0 & 0 \\ 0 & 0 \\ 6 & 6 \\ 1 & 3\end{array}$

$\begin{array}{rr}2 & 6 \\ 17 & 3 \\ 4 & 11 \\ 18 & 7 \\ 21 & 2 \\ 0 & 3 \\ 6 & 2\end{array}$

$13-1$

$\begin{array}{rrr}10 & 3 \\ 1 & 6\end{array}$

$\begin{array}{lll}3 & 5\end{array}$

\footnotetext{
$\S$ Mussel mortality could be measured at several frequencies in a single study; thus, the sum of studies per frequency can be greater than the total number of studies.

${ }^{* *}$ Several risk factor topics could be investigated in a single study; thus, the sum of studies per topic can be greater than the total number of studies.
} 
Table 3. Association measures between mussel mortality and factors of interest $(\mathrm{N}=114$ studies)

\begin{tabular}{lcc}
\hline Association measure & \multicolumn{2}{c}{ Nb. of studies } \\
& Mytilus edulis & Mytilus galloprovincialis \\
& $(66)$ & $(48)$ \\
\hline Comparison of mortality means & 20 & 15 \\
Comparison of mortality proportions & 34 & 20 \\
Comparison of survival curves & 7 & 3 \\
Median survival & 1 & 0 \\
Correlation & 2 & 4 \\
Concentration leading to 50\% & 2 & 5 \\
mortality & & 1 \\
Time leading to 50\% mortality & 0 & \\
\hline
\end{tabular}


Table 4. Factors studied in M. galloprovincialis and reported effect on the mortality risk (23 experimental studies, 25 observation studies). Experimental studies are highlighted in grey; studies accounting for interactions between factors are in bold; in the last column, NR stands for non-relevant.

\begin{tabular}{|c|c|c|c|c|c|}
\hline \multirow[t]{2}{*}{ Studied factors } & \multirow{2}{*}{$\begin{array}{c}\text { Nb. } \\
\text { studies }\end{array}$} & \multicolumn{3}{|c|}{ Effect on mortality risk } & \multirow{2}{*}{$\begin{array}{r}\text { Consistency of } \\
\text { study results }\end{array}$} \\
\hline & & Increase & Decrease & No effect & \\
\hline Pathogens & 8 & & & & \\
\hline Non-identified infectious agent & 1 & $\begin{array}{l}\text { Benaldelmouna et al. } \\
\qquad \text { (2018) }\end{array}$ & & & NR \\
\hline Bacteriological profile & 1 & & & Bernard et al. (2018b) & NR \\
\hline Bacteria Vibrio aestuarianus & 3 & Romero et al. (2014) $)^{1}$ & & $\begin{array}{l}\text { Benaldelmouna et al. } \\
\text { (2018); Romero et al. } \\
{(\mathbf{2 0 1 4})^{2}}^{2}\end{array}$ & No \\
\hline Bacteria Vibrio Splendidus clade & 3 & Romero et al. (2014) $)^{1}$ & & $\begin{array}{c}\text { Benaldelmouna et al. } \\
\text { (2018); Romero et al. } \\
(\mathbf{2 0 1 4})^{2}\end{array}$ & No \\
\hline
\end{tabular}

\footnotetext{
${ }^{1}$ Infection by exposure to contaminated seawater with $10^{10} \mathrm{CFU} / \mathrm{mL}$, with seawater temperature at $25^{\circ} \mathrm{C}$ and in emersion for 8 hours (to simulate hypoxia conditions) ${ }^{2}$ Infection by exposure to contaminated seawater with $10^{10} \mathrm{CFU} / \mathrm{mL}$, with seawater temperature at $15^{\circ} \mathrm{C}$ or at $25^{\circ} \mathrm{C}$
} 
ovata

Presence of epibiotic algae on the shell

Endolithic infestation

Nicastro et al. (2018)

Animal characteristics
Species vs. M. trossulus

\section{7}

3

Dowd and Somero

Shields et al. (2008) No (2013); Schneider

(2008)

${ }^{3}$ Dose effect

${ }^{4}$ In sheltered rocky shores

${ }^{5}$ In shores exposed to waves

${ }^{6}$ Mortality due to trampling (anthropogenic stressor) in the context of recreational or harvesting use of wild beds

${ }^{7}$ Mortality due to a heat wave 
High frequency of individuals having

more than $10 \%$ cytogenetic

abnormalities in haemocytes in the

population

Small size

O’Connor (2010) ${ }^{10}$

\section{Seawater characteristics \\ Elevated temperature}

4
Anestis et al. (2007) ${ }^{11}$;
Dowd and Somero

Gestoso et al. (2016) $)^{14}$

No

$(2013)^{12}$; Gazeau et al.

$(2018)^{13}$
Increased number of thermal stresses

Decreased salinity
1

2 Hamer et al. (2008) ${ }^{16}$

Lenz et al. (2018) ${ }^{15}$

NR

Hamer et al. (2008) $)^{17}$

\footnotetext{
${ }_{9}^{8}$ Different genotypes of $M$. galloprovincialis vs. different hybrid genotypes of M. edulis and M. galloprovincialis

${ }^{9}$ Native genotype of $M$. trossulus vs. introgressed vs. introduced genotype of M. galloprovincialis

${ }^{10}$ Mortality due to epibiotic algae on the shell

${ }^{11}$ Thermal threshold at $24^{\circ} \mathrm{C}$; elevation from $18^{\circ} \mathrm{C}$ to $30^{\circ} \mathrm{C}$ by $0.1^{\circ} \mathrm{C}$ increase per minute (thus in 2 hours in total)

13 Thermal threshold $25^{\circ} \mathrm{C}$; variations from $15.7^{\circ} \mathrm{C}$ to $27.8^{\circ} \mathrm{C}$ and elevation of $1^{\circ} \mathrm{C}$ per week for 3 weeks

16 Salinity from $19^{\circ} \mathrm{C}$ to $29^{\circ} \mathrm{C}$, two thermal stresses separated by 14 day-long recovery phase

${ }^{17}$ Salinity below 28 psu, with seawater temperature at $13^{\circ} \mathrm{C}$
} 
Decreased $\mathrm{pH} /$ Acidification

Bressan et al. (2014) $)^{18}$

Gestoso et al. (2016) ${ }^{19}$

2

Romero et al. (2014) 22

Decreased dissolved oxygen/Hypoxia
Gazeau et al. (2018) ${ }^{20}$;

Bressan et al. $(2014)^{21}$

Romero et al. (2014) $)^{23}$

\section{Characteristics of the farming / fishing}

site

General effect

Coast vs. bay

Sand burial or accumulation
14

5

Bownes and McQuaid
(2010); Fuentes et al.
(1994); Gardner (2013);

Moschino et al. (2017)

$2 \quad$ Nicastro et al. (2008);

Nicastro et al. (2010)

$4 \quad$ Nicastro et al. (2010);

Zardi et al. (2008)

No

Zardi et al. (2006);

${ }^{18}$ Constant $\mathrm{pH}$ of 7.4 for 6 months

${ }^{19}$ When mussels $M$. galloprovincialis are mixed with mussels Xenostrobus securis

${ }^{20}$ Gradual decrease of $0.3 \mathrm{pH}$ units (from 8.01 to 7.98); decrease of 0.1 unit per week for 3 weeks then maintenance for 10 months; irrespective of the seawater temperature between $12-25^{\circ} \mathrm{C}$

${ }^{21}$ Constant $\mathrm{pH}$ of 7.4 for 3 months

${ }^{23}$ With seawater temperature at $15^{\circ} \mathrm{C}$ 
Wave exposure

Wave height

High position on the shore
2

3

Zardi et al. (2008);

Nicastro et al. $(2010)^{24}$

Border vs. central position in the bed

1

Predation

Bownes and McQuaid

(2010); Marquet et al.

$(2013)^{26}$

O'Connor $(2010)^{5}$

No

Nicastro et al. $(2010)^{25}$

$(2017)^{27}$; Plass-Johnson

et al. (2010)

\section{Farming / harvesting practices}

Geographic origin of the spat: local. vs transplanted

\section{3}

Shields et al. (2008)

Bernard et al. (2018a);

24 Bay habitat

${ }^{25}$ Coast habitat

${ }^{26}$ Mortality due to endolith infestation

${ }^{27}$ Mortality due to predation by the polyclad flatworm Imogine mediterranea 
Fuentes et al. (1994);

Gardner (2013) ;

Kovacic et al. (2017);

Ramon et al. (2007)

Position inside the farming structure

Mixed mussel species

Fuentes et al. (1994)

Gestoso et al. $(2016)^{28 .}$

Olabarrial et al. $(2016)^{28}$

Polyculture (fish)

Polyculture (algae Gracilaria

verrucosa)

Re-immersion duration of the mussels

1

before sale $>11$ days

Stocking density during immersion

before transport for sale $(\mathrm{kg} / \mathrm{bag})$

Increasing intensity of human trampling

during bed harvesting

${ }^{28}$ With Xenostrobus securis, invasive species in Galicia, Spain

Theodorou et al. (2017)
Gvozdenovic et al.

(2017)

Ajjabi et al. (2018)

Theodorou et al. (2017)

NR

NR 


\section{Contaminants from the terrestrial and}

7

\section{marine environments}

Total metals (As, Cd, Cr, Cu, Hg, Ni, V, $1 \quad$ Moschino et al. $(2016)^{29}$

NR

$\mathrm{Pb}, \mathrm{Zn}, \mathrm{Al}, \mathrm{Fe})$

$\mathrm{Al}$

As

$\mathrm{Cd}$

NR

As

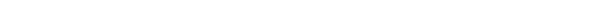

$\mathrm{Cr}$

$\mathrm{Cu}$

$\mathrm{Fe}$

$\mathrm{Hg}$

$\mathrm{Ni}$

$\mathrm{Pb}$

$\mathrm{V}$

$\mathrm{Zn}$

Polycyclic aromatic hydrocarbons

(PAHs)

Polychlorinated biphenyls (PCBs)

Carbamazepine (antiepileptic

pharmaceutical drug)

Phthalates (plasticisers)

Moschino et al. $(2016)^{29}$

Moschino et al. $(2016)^{29}$

1

$1 \quad$ Moschino et al. $(2016)^{29}$

$1 \quad$ Oliveira et al. (2017)

Moschino et al. $(2016)^{29} \quad$ NR

Moschino et al. $(2016)^{29} \quad$ NR

Moschino et al. $(2016)^{29} \quad$ NR

Moschino et al. $(2016)^{29} \quad$ NR

Moschino et al. $(2016)^{29} \quad$ NR

NR

Moschino et al. (2016) ${ }^{29} \quad$ NR

Moschino et al. $(2016)^{29} \quad$ NR

Moschino et al. $(2016)^{29} \quad$ NR

Moschino et al. $(2016)^{29} \quad$ NR

NR

NR

Moschino et al. $(2016)^{29} \quad$ NR

${ }^{29}$ In mussel tissues 
Alkylphenols (detergents, fuel and oil

additives, resins)

Zinc oxide nanoparticles $(\mathrm{ZnO})$

2,4,6-trinitrotoluene (TNT, explosive compound)

Hexahydro-1,3,5,-triazine (RDX,

explosive compound)

Octahydro-1,3,5,7-tetranitro-1,3,5,7-

tetrazocine (HMX, explosive

compound)

Imidazolium ionic liquids (1-butyl-3-

$1 \quad$ Tsarpali et al. (2015)

methylimidazolium and 1-methyl-3-

octylimidazolium tetrafluoroborate),

alternative to conventional organic

solvents

Olive mill wastewater (by-product of

$1 \quad$ Danellakis et al. (2011)

NR

olive oil production)

Landfill leachate

Tsarpali et al. (2012)

NR

Climate characteristics

1

Season

8

3

Bernard et al. $(2018 \mathrm{a})^{30}$;

Yes

Nicastro et al. (2008) $)^{31}$,

${ }^{30}$ In France, spring (March-May) vs. other seasons

${ }^{31}$ In South Africa, end of summer (February) vs. other seasons 
Nicastro et al. $(2010)^{32}$

Elevated air temperature

Air vs. seawater thermal range

Anestis et al. (2010) ${ }^{33}$;

${ }_{36}^{35}$ Seawater at $12^{\circ} \mathrm{C}$ and air from 20 to $30^{\circ} \mathrm{C}$

${ }^{37} 33^{\circ} \mathrm{C}$, three times 
Table 5. Factors studied in M. edulis and reported effect on the mortality risk (28 experimental studies, 38 observation studies). Experimental studies are highlighted in grey; studies accounting for interactions between factors are in bold; in the last column, NR stands for non-relevant.

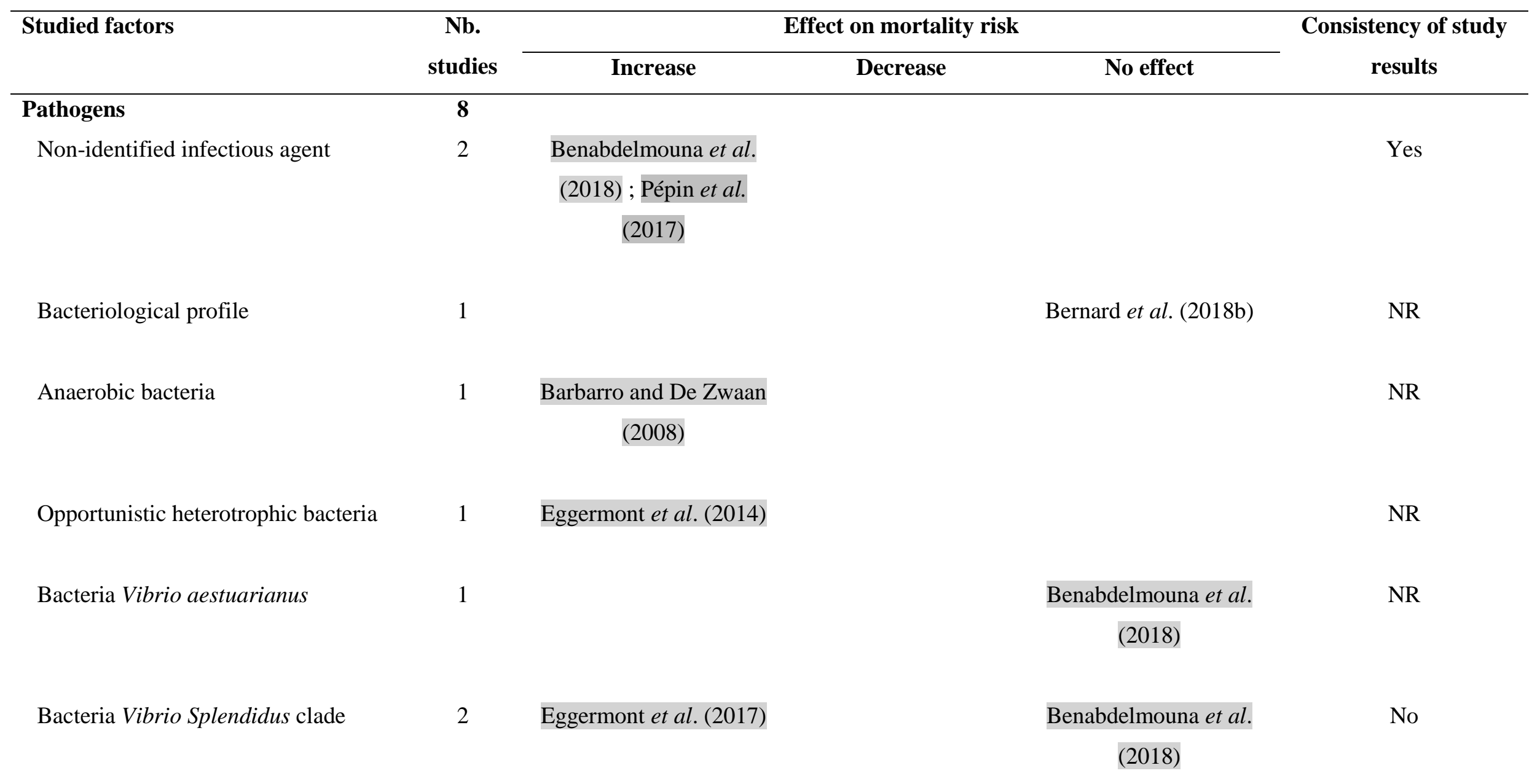




$$
\text { (2018) }
$$

(2018); Bernard et al.

$$
\text { (2018b) }
$$

Toxic algae Karlodinium armiger

Presence of epibiotic algae on the shell

\section{2}

3

Species vs. M. trossulus

Interspecific genotype
Binzer et al. (2018)

O'Connor (2010)
NR

No

O'Connor (2010)

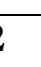

$2 \quad$ Fuentes et al. $(2002)^{3}$;

Lowen $(2008)^{4}$

\footnotetext{
${ }^{1}$ In sheltered rocky shores

${ }^{2}$ In shores exposed to waves
${ }^{2}$ sheltered rocky shores
} 
Pépin et al. (2017)

Pépin et al. (2017)

1

Tremblay et al. (1998)

4

Benabdelmouna and

Ledu (2016);

Pépin et al. (2017);

Pépin et al. (2018)

population

Neoplastic process in the haemocytes

Pépin et al. (2018)

Small size

\author{
Altieri and Witman \\ (2006) $^{6}$; Dionne et al. \\ (2006) $^{7}$; Lauzon-Gay et \\ al. (2005); Lauzon-Gay \\ et al. (2005)
}

Myrand and Gaudreault

(1995)

Tremblay et al. (1998);

Tsuchiya (1983) 
(2006) $^{6}$; Hiebental et al.

(2013)

Low condition index

Low energetic resources / high

energetic needs for maintenance

End of spawning period

Spawning period

Lipofuscin accumulation

Shell resistance

1

Seawater characteristics

Elevated temperature

12

Bernard et al. (2018a) ${ }^{9}$

Clements et al. (2018) ${ }^{10}$;
Cottrell et al. $(2016)^{11}$;

Mallet et al. (1990)

NR

Yes

Tremblay et al. (1998)

Myrand et al. (2000)

NR

NR

NR

Hiebental et al. (2013)

NR

Ali and Taylor (2010) ${ }^{17}$;

No

Stevens and Gobler

$(2018)^{18}$

${ }^{9}$ Over $19-20{ }^{\circ} \mathrm{C}$ 
Hiebenthal et al.

\section{$(2013)^{12}$; Hutchison et \\ al. (2016) ${ }^{13}$;}

Incze et al. (1980) $)^{14}$;

Jones et al. (2009);

Jones et al. (2010); Lenz

et al. $(2018)^{15}$;

Wang et al. (2018) ${ }^{16}$

Increased number of thermal stresses

Stevens and Gobler

(2018) $^{21}$;
Clements et al. (2018);

No

${ }^{10} 22^{\circ} \mathrm{C}$ vs. $16^{\circ} \mathrm{C}$

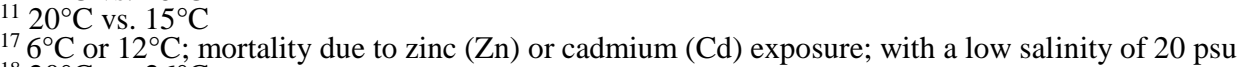

${ }_{18} 20^{\circ} \mathrm{C}$ vs. $26^{\circ} \mathrm{C}$

${ }^{12}$ Over $20-25^{\circ} \mathrm{C}$

${ }^{13}$ From $8^{\circ} \mathrm{C}$ to $20^{\circ} \mathrm{C}$; with several burial depth

${ }^{14}$ Thermal threshold at $20^{\circ} \mathrm{C}$, with a rapid decline of total chlorophyll concentration

${ }_{15}^{15} \mathrm{From} 15^{\circ} \mathrm{C}$ to $28^{\circ} \mathrm{C}$, two thermal stresses separated by 14 day-long recovery phases

$195^{\circ} \mathrm{C}$

${ }^{20} 20 \mathrm{psu}$; mortality due to zinc ( $\mathrm{Zn}$ ) or cadmium (Cd) exposure

${ }^{21} \mathrm{pH}=7.2$ vs. 9.7 
Variations of dissolved oxygen

concentration

Low quantity of food

Low phytoplankton diversity index
Stevens and Gobler

$(2018)^{23}$; Stevens and

Gobler (2018) ${ }^{23}$
Characteristics of the farming /

\section{fishing site}

General effect
10

Bernard et al. (2018a);

Glize et al. (2017); Glize

and Gourmelen (2018);

Penney et al. (2006);

Pépin et al. (2017)

Lauzon-Gay et al.

No

(2005); Mallet et al.

(1987); Mallet et al.

(1990); Myrand and

Gaudreault (1995);

Stirling and Okumus

(1994)

Increased burial sediment depth

Hutchison et al. (2016)

Hutchison et al. (2016)

No

${ }_{22}^{2} \mathrm{pH}=6.5$
$2.0 \mathrm{mg} / \mathrm{L}$ vs. $8.0 \mathrm{mg} / \mathrm{L}$ during 4 weeks

${ }^{24}$ Rapid decline of total chlorophyll concentration
NR

NR 
Increased burial sediment duration

Cottrell et al. (2016);

Hutchison et al. (2016);

Hutchison et al. (2016);

Fine burial sediment fraction $(<0.3$

$\mathrm{mm})$

Cottrell et al. (2016);

Hutchison et al. (2016)

High concentration (1\%) of organic

1

Cottrell et al. (2016)

matter in burial fine sediment

Wave exposure

2

Spatially complex habitat (with small

inter-structural spaces)

High position on the shore

Predation

\section{O'Connor (2010)}

Petraitis (1998) ${ }^{27}$;

Tsuchiya (1987)

Bertolini et al. (2018) ${ }^{25}$;

Bertolini et al. $(2018)^{26}$;

Brousscau et al.
Yes

Yes

NR

O'Connor (2010)

No

Bertolini et al.

Bertolini et al. (2018)

No

$\mathbf{( 2 0 1 8}^{25}$

Yes

Altieri and Witman

No

$(2006)^{6}$

${ }_{25}$ Mortality due to predation by the shore crab Carcinus maena

26 Mortality due to predation by the starfish Asterias ruben

${ }^{27}$ Mortality due to the predatory snail Nucella lapillus 
(2014) ${ }^{28}$; Brousscau et

$$
\text { al. }(2014)^{28} \text {; }
$$

Christensen et al. (2012);

Christensen et al. (2012);

Dionne et al. (2006) ${ }^{7}$;

Petraitis (1998) ${ }^{27}$; Waser

et al. $(2015)^{25}$

\section{Farming / harvesting practices}

Geographic origin of the spat

\section{2}

\section{Bernard et al. (2018a); \\ Myrand and Gaudreault}

$$
\text { (1995); }
$$

Mallet et al. (1987);

Mallet et al. (1990)

\section{Geographic origin of the spat: local.}

vs transplanted

${ }^{28}$ Mortality due to predation by the Asian shore crab Hemigrapsus sanguineus

${ }^{29}$ Local origin with mortality events vs. transplanted origin without mortality events, France
Glize et al. (2017); Glize

and Gourmelon (2018);

SMIDAP (2016-2017)

Glize et al. (2017) ${ }^{29}$;

No

Mallet et al. (1987); 
Mallet et al. (1990);

Myrand and Gaudreault

(1995) ;

SMIDAP (2016) ${ }^{29}$;

Stirling and Okumus

(1994)

Origin of the spat: use of mussels

Christensen et al.

Christensen et al.

No

collected in suspended culture vs.

$(2012)^{25}$

(2012) $^{25}$

mussels collected from natural

bottom beds (for bottom culture

production)

Depth of the farming structure: deep

Karayucel (2000) $)^{32}$

${ }^{30}$ Suspended cages at $16 \mathrm{~m}$ (open water) vs. $6 \mathrm{~m}$ depth (lagoon)

${ }^{31}$ Lantern nets at $6 \mathrm{~m}$ vs. $2 \mathrm{~m}$ depth

32 Inflow or outflow of the raft

33273 mussels $/ 30 \mathrm{~cm}$ section of a sock, small sized mussels

3430 mussels per cage ( 15 M. edulis and 15 M. trossulus) 
no depuration of the mussels,

with ice storage or at ambient temperature during transport ice storage during transport vs. no depuration pre-transportation + storage at ambient temperature during transport 
Anti-biofouling treatment with

potassium monopersulfphonate triple

salt

$24 \mathrm{H}$ pre-transportation anti-

biofouling treatment (vinegar, brine

or lime), with or without seawater

rinsing

After transportation anti-biofouling

treatment (vinegar, brine or lime)
Paetzold and Davidson

(2001)

Vickerson (2009)

NR

Vickerson (2009)

NR

\section{Contaminants from the terrestrial}

\section{and marine environments}

$\mathrm{Cd}$

$1 \quad$ Ali and Taylor $(\mathbf{2 0 1 0})^{20}$

NR

$\mathrm{Zn}$

$1 \quad$ Ali and Taylor $(\mathbf{2 0 1 0})^{20}$

NR

Untreated municipal sewage

$1 \quad$ Akaishi et al. (2007)

NR

Diesel oil

$1 \quad$ Suni et al. (2007)

NR 
Season

Elevated air temperature
3

Bernard et al. (2018a) ${ }^{39}$;

Myrand et al. $(2000)^{40}$

$4 \quad$ Jones et al. (2009);
Jones et al. (2010);
Tsuchiya (1987)

Jones et al. (2010);
Tsuchiya (1987)

Mallet et al. (1987)

No
Travers et al. (2016)

No

Jones et al. (2009); Jones Peden et al. (2018) ${ }^{41}$

No

et al. (2010) 
Figure 1. PRISMA workflow diagram representing the study selection process.

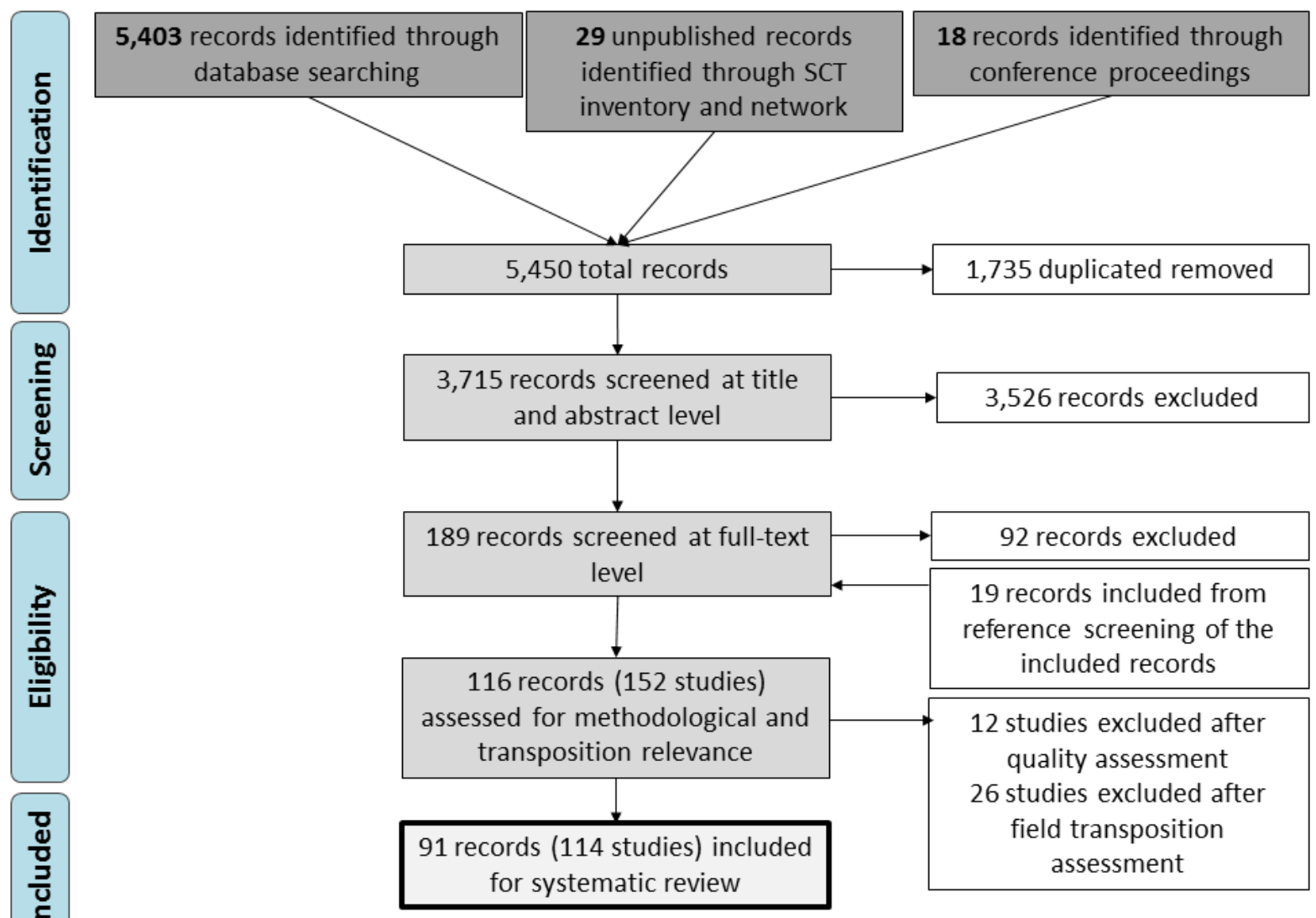


Figure 2. Yearly distribution of the number of studies on risk factors for mussel mortalities from 1980 to 2018, per mussel species $(\mathrm{N}=114)$. The dotted black line separates included studies using the initial temporal inclusion criteria (i.e. published after 2006) from additional older studies.

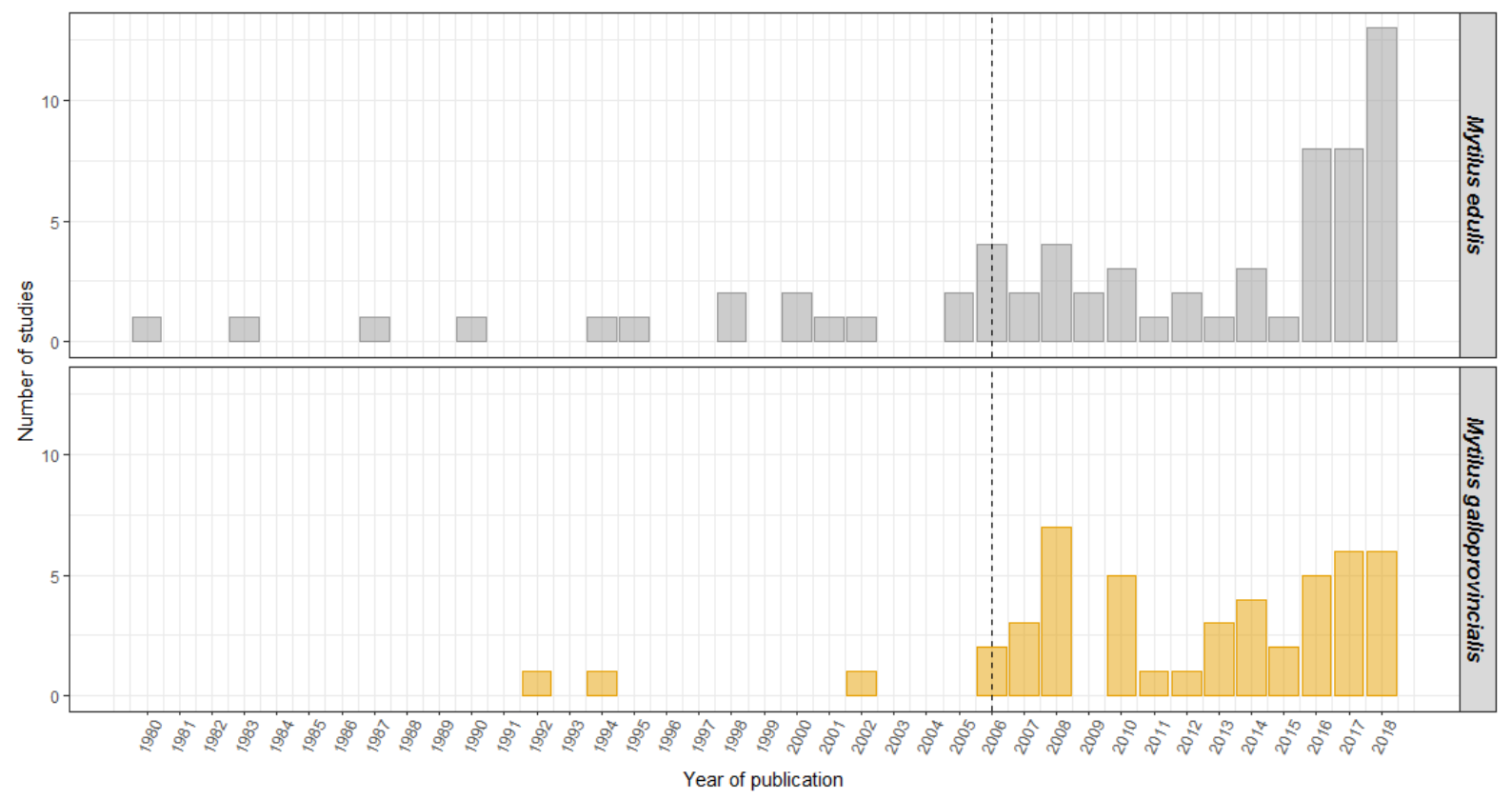


Figure 3. Geographical distribution of the included studies about (a) Mytilus edulis $(\mathrm{N}=66)$, (b) Mytilus galloprovincialis $(\mathrm{N}=48)$. Grey shading indicates countries without included research about mussel mortality risk factors. The other colours represent the number of studies for each country.

(a) Mytilus edulis

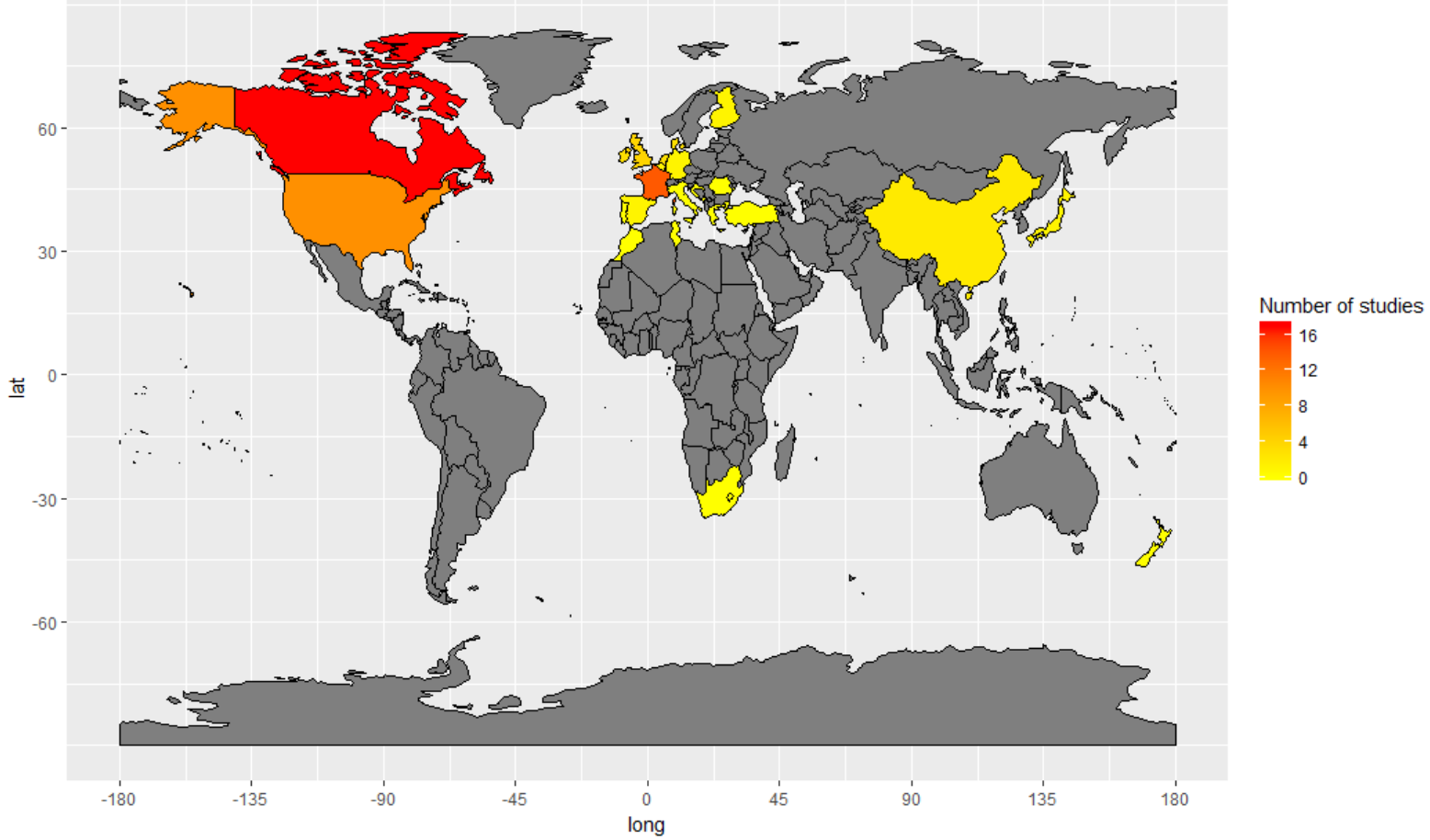

(b) Mytilus galloprovincialis

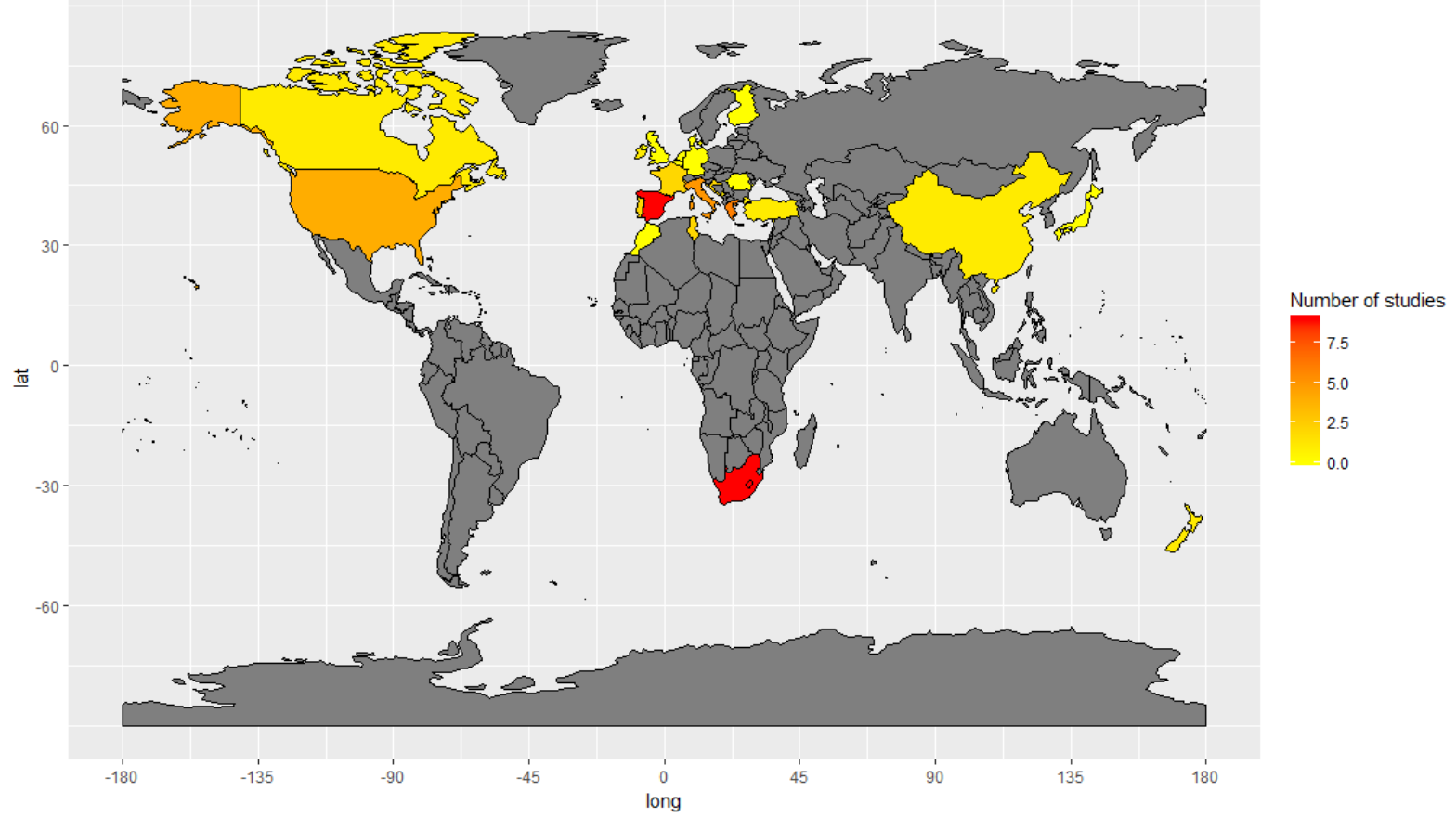


Figure 4. Graphical solution of the MCA on the first and second factorial axis, which explained respectively $15.5 \%$ and $12.5 \%$ of the total inertia of the 14 variables, for the 13 descriptive characteristics of $\mathrm{N}=114$ studies related to risk factors of mussel mortality. Each variable is plotted on the graph according to the coordinates on factorial axis 1 (horizontal) and 2 (vertical)

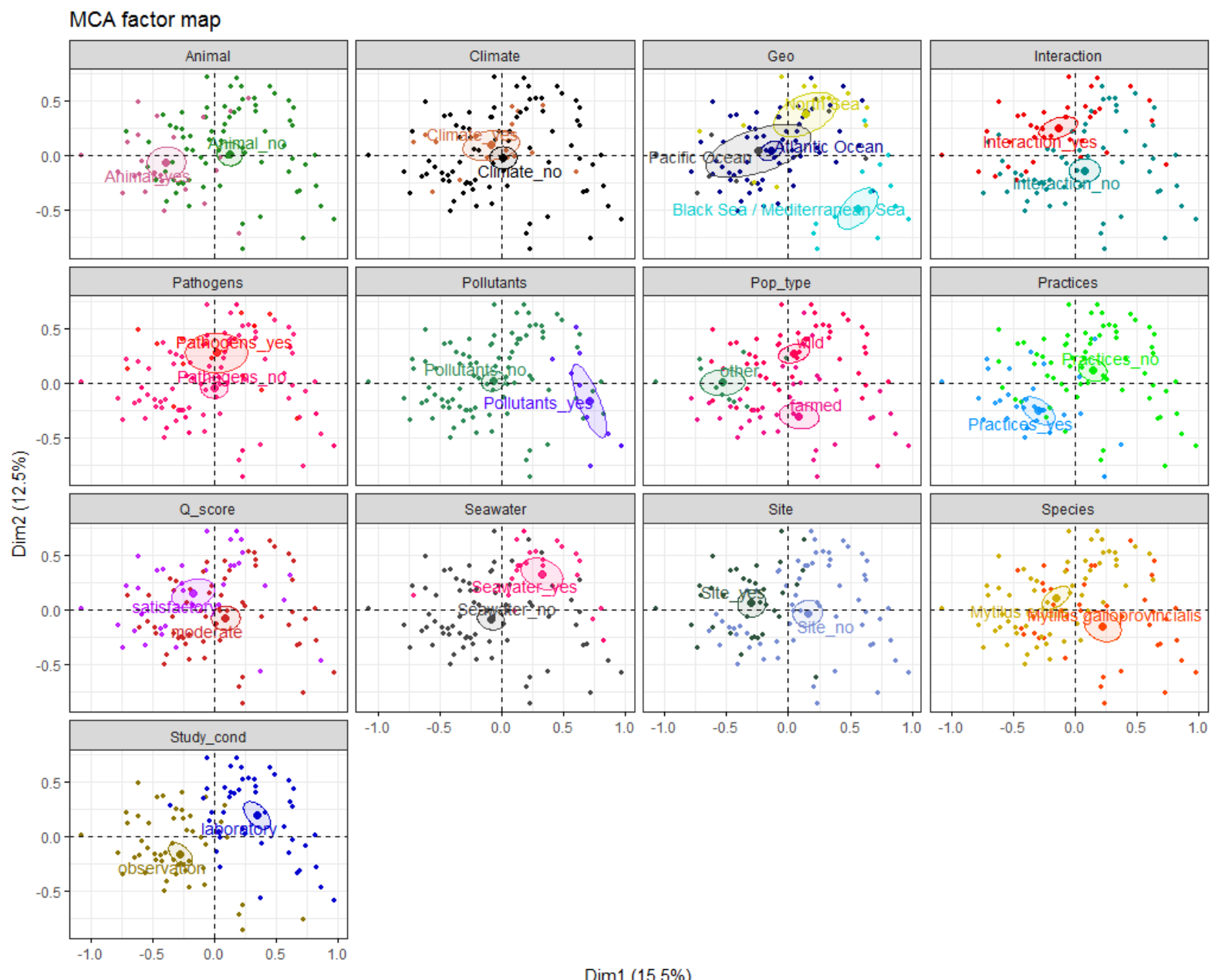

$\operatorname{Dim} 1(15.5 \%)$ 
Figure 5. Number of studies investigating interactions between risk factor topics of mussel mortality by mussel species. The upper part of the matrix is for M. edulis and the lower part is for M. galloprovincialis, e.g. interactions between mussel and site characteristics were explored by 4 studies for M. edulis and 1 study for M. galloprovincialis.

\begin{tabular}{|c|c|c|c|c|c|c|c|c|c|c|c|c|c|}
\hline \multicolumn{14}{|c|}{ M. edulis } \\
\hline & \multicolumn{2}{|c|}{ Mussel } & \multirow{2}{*}{\multicolumn{2}{|c|}{$\begin{array}{c}\text { Site } \\
4\end{array}$}} & \multirow{2}{*}{\multicolumn{2}{|c|}{$\begin{array}{c}\text { Climate } \\
0\end{array}$}} & \multicolumn{2}{|c|}{ Seawater } & \multicolumn{2}{|c|}{ Pollutants } & \multicolumn{2}{|c|}{ Pathogens } & Practices \\
\hline \multirow{3}{*}{$\begin{array}{l}\text { Mussel } \\
\text { Site } \\
\text { Climate }\end{array}$} & 0 & 2 & & & & & \multicolumn{2}{|c|}{0} & \multicolumn{2}{|c|}{0} & \multicolumn{2}{|c|}{1} & \\
\hline & \multicolumn{2}{|c|}{1} & 2 & 3 & \multicolumn{2}{|c|}{1} & \multicolumn{2}{|c|}{2} & \multicolumn{2}{|c|}{0} & \multicolumn{2}{|c|}{1} & 4 \\
\hline & \multicolumn{2}{|c|}{0} & \multicolumn{2}{|c|}{0} & 0 & 1 & \multicolumn{2}{|c|}{0} & & & \multicolumn{2}{|c|}{0} & 1 \\
\hline Seawater & \multicolumn{2}{|c|}{0} & \multicolumn{2}{|c|}{0} & & & 1 & 3 & \multicolumn{2}{|c|}{1} & \multicolumn{2}{|c|}{0} & 0 \\
\hline Pollutants & \multicolumn{2}{|c|}{0} & \multicolumn{2}{|c|}{0} & & & \multicolumn{2}{|c|}{0} & 0 & 0 & \multicolumn{2}{|c|}{0} & 0 \\
\hline Pathogens & \multicolumn{2}{|c|}{1} & \multicolumn{2}{|c|}{1} & & & \multicolumn{2}{|c|}{1} & \multicolumn{2}{|c|}{0} & 0 & 0 & 0 \\
\hline Practices & & 0 & & & & & & & & & & & 0 \\
\hline
\end{tabular}


Appendix I. Search equation used for searches in the Web of Science database.

Appendix II. Citations excluded at the full text examination step and reasons for their exclusion ( $\mathrm{N}=117$ citations).

Appendix III. Table synthetizing key results of the 114 studies included in the narrative synthesis.

Appendix IV. Graphical solution of the MCA on the first and second factorial axis, which explained respectively $15.5 \%$ and $12.5 \%$ of the total inertia of the 14 variables, for descriptive characteristics of 114 studies related to risk factors of mussel mortality. Each variable is plotted on the graph according to the coordinates on factorial axis 1 (horizontal) and 2 (vertical). 
Appendix I. Search equation used for search in the Web of Science database

\begin{tabular}{|c|c|c|}
\hline $\begin{array}{c}\text { Request } \\
\text { code }\end{array}$ & Field & $\begin{array}{c}\text { Request } \\
\text { (topic) }\end{array}$ \\
\hline 1. & Bivalves species & $\begin{array}{l}\text { mussel* } \\
\text { OR "Mytilus edulis" OR "M* edulis" OR "blue mussel*" } \\
\text { OR "Mytilus galloprovincialis" OR "M* galloprovincialis " }\end{array}$ \\
\hline 2. & $\begin{array}{l}\text { Mortality } \\
\text { Disease } \\
\text { Immunity }\end{array}$ & $\begin{array}{l}\text { mortalit* OR "summer mortalit*" OR survival } \\
\text { OR diseas* OR infection* OR illness OR epizoot* OR "health } \\
\text { effect" } \\
\text { OR immun* OR immunit* OR "immun* system*" }\end{array}$ \\
\hline 3. & & 1 AND 2 \\
\hline 4. & $\begin{array}{l}\text { Risk factor topics } \\
\text { Husbandry practices } \\
\text { Animal } \\
\text { Seawater characteristics } \\
\text { Pollutants from terrestrial and } \\
\text { marine environments } \\
\text { Geographical characteristics } \\
\text { Pathogens }\end{array}$ & $\begin{array}{l}\text { "risk* factor*" OR stress OR factor* OR multifactor* } \\
\text { OR husbandry OR management OR farming OR rearing OR } \\
\text { "farm* practice*" OR "rear* practice*" OR aquaculture OR } \\
\text { cultivation OR "shellfish* culture*" } \\
\text { OR genetics* OR ploidy OR triploid* OR diploid* OR } \\
\text { energetic OR physiol* OR age OR grow* OR weight OR } \\
\text { length OR size } \\
\text { OR environmental OR environment OR "environ* interact*" } \\
\text { OR temperature OR salinity OR pH OR acidification } \\
\text { OR pollut* OR *chemical* OR contaminant* OR "*water* } \\
\text { qualit*" } \\
\text { OR plan?ton OR sediment OR hydrodynamic* OR spatial OR } \\
\text { temporal OR "marine current" OR “*water current" } \\
\text { OR pathogen* OR virus OR parasite* OR bacteri* } \\
\text { OR OsHV* OR "Ostreid herpesvirus" OR herpes OR vibrio OR } \\
\text { "v* aestuarianus" OR "v* splendidus" OR perkinsus OR } \\
\text { Marteilia OR bonamia OR "v* tapetis" OR mi?rocytos } \\
\text { OR recruitment OR settlement OR "larval abundance" }\end{array}$ \\
\hline 5. & & 3 AND 4 \\
\hline 6. & Human foodborne pathogens & $\begin{array}{l}\text { norovirus OR "vibrio parahaemolyticus" OR "vibrio } \\
\text { vulnificus" OR “vibrio cholerae" }\end{array}$ \\
\hline 7. & & 5 NOT 6 \\
\hline 8. & Time period & $2006-2017$ \\
\hline 9. & & 7 AND 9 \\
\hline
\end{tabular}


Appendix II. Citations excluded at the full text examination step and reasons for their exclusion ( $\mathrm{N}=117$ citations)

\begin{tabular}{|c|c|}
\hline Citation & Reason(s) for exclusion \\
\hline $\begin{array}{l}\text { Arzul, I., Chollet, B., et al. (2017). Suspicion of infection with Marteilia } \\
\text { refringens in mussels from Norway. Institute of Marine Research, Po Box 1870, } \\
\text { NORDES } 517 \text { Bergen, Norway, Ref. Ifremer LGPMM/PAT/EURL/DS/BC/IA 17- } \\
032,2 \text { p. }\end{array}$ & Full text not available \\
\hline $\begin{array}{l}\text { Avelelas, F., R. Martins, et al. (2017). Efficacy and Ecotoxicity of Novel Anti- } \\
\text { Fouling Nanomaterials in Target and Non-Target Marine Species. Marine } \\
\text { Biotechnology 19(2): 164-174. }\end{array}$ & Low field transposition score \\
\hline $\begin{array}{l}\text { Ayad, M. A., M. A. Fdil, et al. (2011). Effects of Cypermethrin (Pyrethroid } \\
\text { Insecticide) on the Valve Activity Behavior, Byssal Thread Formation, and } \\
\text { Survival in Air of the Marine Mussel Mytilus galloprovincialis. Archives of } \\
\text { Environmental Contamination and Toxicology 60(3): 462-470. }\end{array}$ & Low field transposition score \\
\hline $\begin{array}{l}\text { Babarro, J. M. F., Labarta, U., et al. (2007). Energy metabolism and performance } \\
\text { of Mytilus galloprovincialis under anaerobiosis. Journal of the Marine Biological } \\
\text { Association of the United Kingdom 87(4): 941-946. }\end{array}$ & $\begin{array}{l}\text { Exposure: risk factors for mortality not } \\
\text { examined }\end{array}$ \\
\hline $\begin{array}{l}\text { Banni, M., Sforzini, S., et al. (2017). Assessing the impact of Benzo[a]pyrene on } \\
\text { Marine Mussels: Application of a novel targeted low density microarray } \\
\text { complementing classical biomarker responses. Plos One 12(6). }\end{array}$ & $\begin{array}{l}\text { Outcome : mortality risk is not the } \\
\text { focus }\end{array}$ \\
\hline $\begin{array}{l}\text { Basti, L., Endo, M., et al. (2010). Histopathological effects of the toxic } \\
\text { dinoflagellate Heterocapsa circularisquama on short-neck clam Ruditapes } \\
\text { philippinarum and blue mussel Mytilus galloprovincialis. Aquaculture, San } \\
\text { Diego, California, USA. }\end{array}$ & $\begin{array}{l}\text { Exposure: risk factors for mortality not } \\
\text { examined }\end{array}$ \\
\hline $\begin{array}{l}\text { Basti, L., Endo, M., et al. (2013). Sequencing of organ damage in the } \\
\text { Mediterranean mussel Mytilus galloprovincialis following exposure to the } \\
\text { harmful alga Heterocapsa circularisquama. Aquaculture, Nashville, Tennessee, } \\
\text { USA. }\end{array}$ & $\begin{array}{l}\text { Outcome : mortality risk is not the } \\
\text { focus }\end{array}$ \\
\hline $\begin{array}{l}\text { Bat, L., F. Uestuen, et al. (2013). Effects of some heavy metals on the sizes of } \\
\text { the mediterranean mussel Mytilus galloprovincialis Lamarck, 1819. Fresenius } \\
\text { Environmental Bulletin 22(7): 1933- } 1938 .\end{array}$ & $\begin{array}{l}\text { Low field transposition score ( } 2 \\
\text { studies) }\end{array}$ \\
\hline $\begin{array}{l}\text { Benabdelmouna, A., Garcia, C., Ledu, C., Lamy, P., Maurouard, E., Degremont, L. } \\
\text { (2018). Mortality investigation of Mytilus edulis and Mytilus galloprovincialis in } \\
\text { France: An experimental survey under laboratory conditions. Aquaculture 495, } \\
\text { 831-841. }\end{array}$ & $\begin{array}{l}\text { Low quality score to identify risk } \\
\text { factors ( } 1 \text { study) }\end{array}$ \\
\hline $\begin{array}{l}\text { Benabdelmouna, A., Saunier, A., et al. (2018). Genomic abnormalities affecting } \\
\text { mussels (Mytilus edulis-galloprovincialis) in France are related to ongoing } \\
\text { neoplastic processes, evidenced by dual flow cytometry and cell monolayer } \\
\text { analyses. Journal of Invertebrate Pathology 157: 45-52. }\end{array}$ & $\begin{array}{l}\text { Outcome : mortality risk is not the } \\
\text { focus }\end{array}$ \\
\hline $\begin{array}{l}\text { Bernard, I. and Charles, M. (2017). Investigation on blue mussel high mortality } \\
\text { in France: a phenomenon with high spatio-temporal variability but no } \\
\text { conclusive cause. 2nd International Symposium on the Advances in Marine } \\
\text { Mussel Research, Sète, France. }\end{array}$ & $\begin{array}{l}\text { Duplicate not detected at the title and } \\
\text { abstract step }\end{array}$ \\
\hline $\begin{array}{l}\text { Bernard, I., Allain, G. (2016). Les mortalités de moules en } 2014 \text { et } 2015 \text { vues par } \\
\text { les professionnels - Compte-rendu de la phase } 1 \text { : synthèse sur l'émergence, la } \\
\text { propagation et l'installation des mortalités. Rapport technique CRC Bretagne } \\
\text { Nord, } 28 \text { p. }\end{array}$ & $\begin{array}{l}\text { Low quality score to identify risk } \\
\text { factors }\end{array}$ \\
\hline $\begin{array}{l}\text { Bihari, N., Fafandel, M., Piskur, V. (2007). Polycyclic aromatic hydrocarbons and } \\
\text { ecotoxicological characterization of seawater, sediment, and mussel Mytilus } \\
\text { galloprovincialis from the Gulf of Rijeka, the Adriatic Sea, Croatia. Archives of } \\
\text { Environmental Contamination and Toxicology 52, 379-387. }\end{array}$ & $\begin{array}{l}\text { - Low quality score to identify risk } \\
\text { factors } \\
\text { - Low field transposition score }\end{array}$ \\
\hline $\begin{array}{l}\text { Bodkin, J. L., Coletti, H. A., et al. (2018). Variation in abundance of Pacific Blue } \\
\text { Mussel (Mytilus trossulus) in the Northern Gulf of Alaska, 2006-2015. Deep-Sea } \\
\text { Research Part II-Topical Studies in Oceanography 147: 87-97. }\end{array}$ & $\begin{array}{l}\text { Outcome : mortality risk is not the } \\
\text { focus }\end{array}$ \\
\hline $\begin{array}{l}\text { Bownes, S. J. and McQuaid, C. D. (2009). Mechanisms of habitat segregation } \\
\text { between an invasive and an indigenous mussel: settlement, post-settlement } \\
\text { mortality and recruitment. Marine Biology 156(5): 991-1006. }\end{array}$ & $\begin{array}{l}\text { Exposure: risk factors for mortality not } \\
\text { examined }\end{array}$ \\
\hline $\begin{array}{l}\text { Brenner, M., K. Broeg, et al. (2012). Effect of air exposure on lysosomal tissues } \\
\text { of Mytilus edulis L. from natural intertidal wild beds and submerged culture } \\
\text { ropes. Comparative Biochemistry and Physiology a-Molecular \& Integrative } \\
\text { Physiology 161(3): 327-336. }\end{array}$ & Low field transposition score \\
\hline
\end{tabular}


Bullard, S., Whithlatch, R., et al. (2006). Impacts of the colonial ascidian didemnum sp. on mussels, oysters and scallops. 98th Annual meeting of the National Shellfisheries Association, Monterey, California USA.

Bulleri, F., Airoldi, L., et al. (2006). Positive effects of the introduced green alga, Codium fragile ssp tomentosoides, on recruitment and survival of mussels. Marine Biology 148(6): 1213-1220.

Burgos-Aceves, M. A. and Faggio, C. (2017). An approach to the study of the immunity functions of bivalve haemocytes: Physiology and molecular aspects. Fish \& Shellfish Immunology 67: 513-517.

Burioli, E. A. V. (2017). First description of disseminated neoplasia in Mytilus edulis in Northern Brittany (France) and development of a rapid diagnostic tool. 2nd International Symposium on the Advances in Marine Mussel Research, Sète, France.

Calderwood, J., O'Connor, N. E., et al. (2014). Determining optimal duration of seed translocation periods for benthic mussel (Mytilus edulis) cultivation using physiological and behavioural measures of stress. Aquaculture 434: 288-295.

Capelle, J. J., van Stralen, M. R., et al. (2017). Population dynamics of subtidal blue mussels Mytilus edulis and the impact of cultivation. Aquaculture Environment Interactions 9: 155-168.

Capelle, J. J., Wijsman, J. W. M., et al. (2014). Spatial organisation and biomass development after relaying of mussel seed. Journal of Sea Research 85: 395403.

Capelle, J. J., Wijsman, J. W. M., et al. (2016). Effect of seeding density on biomass production in mussel bottom culture. Journal of Sea Research 110: 815.

Capelle, J., Wisjman, J., et al. (2012). The effect of spatial heterogeneity in mussel density on the productivity of a commercial mussel bed. 104th Annual meeting of the National Shellfisheries Association, Seattle, Whashington, USA. Charles, M. (en cours : 2016-2019). Surmortalités des moules (Mytilus edulis et Mytilus galloprovincialis). Etude des pathogènes et des composés chimiques qui peuvent influencer l'état physiologique des moules.

Christensen, H. T., Dolmer, P., et al. (2015). Aggregation and attachment responses of blue mussels, Mytilus edulis-impact of substrate composition, time scale and source of mussel seed. Aquaculture 435: 245-251.

Coppola, F., A. Almeida, et al. (2017). Biochemical impacts of $\mathrm{Hg}$ in Mytilus galloprovincialis under present and predicted warming scenarios. Science of the Total Environment 601: 1129-1138.

Coray, C. (2007). Assessing the health of Halifax Harbour's intertidal ecosystem: Impacts of marine pollution on community structure, reproductive health of key predator populations (Nucella lapillus), and immunomodulation in blue mussels (Mytilus edulis and Mytilus trossulus). Masters Abstracts International. Vol. 45, no. 05: 143.

CREOCEAN (2014). Etude sur l'origine des mortalités de moules sur le secteur d'élevage de Oye-Plage et Marck. Rapport technique CRC Normandie-Mer du Nord, 125 p.

de los Rios, A., Perez, L., et al. (2016). Measuring biological responses at different levels of organisation to assess the effects of diffuse contamination derived from harbour and industrial activities in estuarine areas. Marine Pollution Bulletin 103(1-2): 301-312.

Deruytter, D., Vandegehuchte, M. B., et al. (2017). Salinity, Dissolved Organic Carbon, and Interpopulation Variability Hardly Influence the Accumulation and Effect of Copper in Mytilus edulis. Environmental Toxicology and Chemistry 36(8): 2074-2082.

Domeneghetti, S., Varotto, L., et al. (2014). Mortality occurrence and pathogen detection in Crassostrea gigas and Mytilus galloprovincialis close-growing in shallow waters (Goro lagoon, Italy). Fish \& Shellfish Immunology 41(1): 37-44. Drapeau, A., Comeau, L. A., et al. (2007). The effect of sock spacing on the productivity of mussel on a longline system. Canadian technical report of fisheries and aquatic sciences. 2685: 22.

Eggermont, M., Tamanji, A., et al. (2014). Isolation of blue mussel Mytilus edulis pathogenic Vibrios from wildcaught adults. European Aquaculture Society conference, Donostia-San Sebastian, Spain.

Fafandel, M. and Bihari, N. (2007). PAH content and toxicity of sediment, seawater and mussel tissue in Gulf of Rijeka. CIESM Congress Proceedings,
Exposure: risk factors for mortality not examined

Outcome : mussel mortality is not the focus

- Study type : review study

- Outcome : mortality risk is not the focus

Exposure: risk factors for mortality not examined

Outcome : mortality risk is not the focus

Outcome : mortality risk is not the focus

Outcome : mortality risk is not the focus

Outcome : mortality risk is not the focus

Duplicate not detected at the title and abstract step

Full text not available: ongoing PhD

Outcome : mortality risk is not the focus

Low field transposition score

Full text not available

Low quality score to identify risk factors

- Outcome : mortality risk is not the

focus

- Exposure: risk factors for mortality not examined

Outcome : mortality risk is not the focus

- Exposure: risk factors for mortality not examined - Study type : descriptive study Outcome : mortality risk is not the focus

Duplicate not detected at the title and abstract step

Outcome : mortality risk is not the focus 


\begin{tabular}{|c|c|}
\hline Rapp. Comm. int. Mer Médit. & \\
\hline $\begin{array}{l}\text { Faria, M., Soares, A. M. V. M., et al. (2018). Effects of Camellia sinensis crude } \\
\text { saponin on survival and biochemical markers of oxidative stress and } \\
\text { multixenobiotic resistance of the Mediterranean mussel, Mytilus } \\
\text { galloprovincialis. Science of the Total Environment 625: 1467-1475. }\end{array}$ & Full text not available \\
\hline $\begin{array}{l}\text { Galinou-Mitsoudi, S., Savvidis, Y., et al. (2006). Interaction between mussel } \\
\text { culture and hydrodynamics: a preliminary study in the gulfs of Thessaloniki and } \\
\text { Thermaikos, Greece. Journal of Biological Research-Thessaloniki 6: 139-145. }\end{array}$ & $\begin{array}{l}\text { Exposure: risk factors for mortality not } \\
\text { examined }\end{array}$ \\
\hline $\begin{array}{l}\text { Garcia, C., Osta Amigo, A., et al. (2016). Mortality of mussels in France. Annual } \\
\text { Meeting of the National Reference Laboratories for Mollusc Diseases, Nantes, } \\
\text { France. }\end{array}$ & $\begin{array}{l}\text { Duplicate not detected at the title and } \\
\text { abstract step }\end{array}$ \\
\hline $\begin{array}{l}\text { Garcia, C., Osta Amigo, A., et al. (2016). Mortality of mussels in France. Annual } \\
\text { Meeting of the National Reference Laboratories for Mollusc Diseases, Nantes, } \\
\text { France. }\end{array}$ & $\begin{array}{l}\text { Exposure: risk factors for mortality not } \\
\text { examined }\end{array}$ \\
\hline $\begin{array}{l}\text { Garcia, C., Ropert, M., et al. (2017). Atypical Marteilia refringens infection in } \\
\text { mussels in Normandy, France. Annual Meeting \& Technical Workshop of NRLs } \\
\text { for Mollusc diseases, Oranmore, Ireland. }\end{array}$ & $\begin{array}{l}\text { Exposure: risk factors for mortality not } \\
\text { examined }\end{array}$ \\
\hline $\begin{array}{l}\text { Garner, Y. L. and Litvaitis, M. K. (2013). Effects of wave exposure, temperature } \\
\text { and epibiont fouling on byssal thread production and growth in the blue } \\
\text { mussel, Mytilus edulis, in the Gulf of Maine. Journal of Experimental Marine } \\
\text { Biology and Ecology 446: } 52-56 \text {. }\end{array}$ & $\begin{array}{l}\text { - Outcome : mortality risk is not the } \\
\text { focus } \\
\text { - Exposure: risk factors for mortality } \\
\text { not examined }\end{array}$ \\
\hline $\begin{array}{l}\text { Glize, P., Tetard, X., et al. (2010). Elevage conchylicole au large en Baie de } \\
\text { Bourgneuf : Approche zootechnique et cartographique. SMIDAP. } 122 \text { pp. }\end{array}$ & $\begin{array}{l}\text { Outcome : mortality risk is not the } \\
\text { focus }\end{array}$ \\
\hline $\begin{array}{l}\text { Goedknegt, M. A., Bedolfe, S., et al. (2018). Impact of the invasive parasitic } \\
\text { copepod Mytilicola orientalis on native blue mussels Mytilus edulis in the } \\
\text { western European Wadden Sea. Marine Biology Research 14(5): } 497-507 .\end{array}$ & $\begin{array}{l}\text { Outcome : mortality risk is not the } \\
\text { focus }\end{array}$ \\
\hline $\begin{array}{l}\text { Gombac, I., Fonda, I., et al. (2011). Prevalent diseases and pathogens of Slovene } \\
\text { cultured mediterranean mussels (Mytilus galloprovincialis). Slovenian } \\
\text { Veterinary Research Volume 48(SUPPL.13): 98-100. }\end{array}$ & Document in Slovenian \\
\hline $\begin{array}{l}\text { Gombac, M. and Jencic, V. (2010). Protozoan infestation dynamics and } \\
\text { occurrence of neoplasias in digestive gland of Mediterranean mussels (Mytilus } \\
\text { galloprovincialis) in the Slovene sea in correlation with sea temperature, } \\
\text { salinity and oxygenation. Annual Meeting of the National Reference } \\
\text { Laboratories for Mollusc Diseases, Nantes, France. }\end{array}$ & $\begin{array}{l}\text { Outcome : mortality risk is not the } \\
\text { focus }\end{array}$ \\
\hline $\begin{array}{l}\text { Guesdon, S., Travers, M. A., et al. (2017). Microbial balance, and triggering of } \\
\text { recent mussel mortality events in France: is there a link? 2nd International } \\
\text { Symposium on the Advances in Marine Mussel Research, Sète, France. }\end{array}$ & $\begin{array}{l}\text { Duplicate not detected at the title and } \\
\text { abstract step }\end{array}$ \\
\hline $\begin{array}{l}\text { Gulshad, M. (2003). Alagal bloom and mass mortality of fishes and mussels } \\
\text { along Kozhikode coast. Marine Fisheries Information Service, Technical and } \\
\text { extension series. Cochin, India, Central Marine Fisheries Research Institute, } \\
\text { Indian Council of Agricultural Research. } 175 .\end{array}$ & $\begin{array}{l}\text { Publication date }<2006 \text { (error in the } \\
\text { database) }\end{array}$ \\
\hline $\begin{array}{l}\text { Hamer, B., Z. Jaksic, et al. (2008). Effect of hypoosmotic stress by low salinity } \\
\text { acclimation of Mediterranean mussels Mytilus galloprovincialis on biological } \\
\text { parameters used for pollution assessment. Aquatic Toxicology 89(3): 137-151. }\end{array}$ & Low field transposition score (1 study) \\
\hline $\begin{array}{l}\text { Hanna, S. K., R. J. Miller, et al. (2013). Impact of Engineered Zinc Oxide } \\
\text { Nanoparticles on the Individual Performance of Mytilus galloprovincialis. Plos } \\
\text { One 8(4). }\end{array}$ & Low field transposition score \\
\hline $\begin{array}{l}\text { Hernroth, B. E. and Baden, S. P. (2018). Alteration of host-pathogen interactions } \\
\text { in the wake of climate change - Increasing risk for shellfish associated } \\
\text { infections? Environ Res 161: } 425-438 \text {. }\end{array}$ & Study type : review study \\
\hline $\begin{array}{l}\text { Hopkins, G. A., M. Prince, et al. (2016). Desiccation as a mitigation tool to } \\
\text { manage biofouling risks: trials on temperate taxa to elucidate factors } \\
\text { influencing mortality rates. Biofouling 32(1): 1-11. }\end{array}$ & Low field transposition score (1 study) \\
\hline $\begin{array}{l}\text { Ifremer-LERN (2017-2019). Programmation du Centre de Référence de l'Huître - } \\
\text { Moules } 2017 .\end{array}$ & Full text not available \\
\hline $\begin{array}{l}\text { Jones, S. J. and Wethey, D. S. (2010). Mussels, models, and mortality: exploring } \\
\text { the respective roles of air and seawater temperatures in the southern range } \\
\text { limit contraction of Mytilus edulis. Integrative and Comparative Biology 50: E85- } \\
\text { E85. }\end{array}$ & $\begin{array}{l}\text { Duplicate not detected at the title and } \\
\text { abstract step }\end{array}$ \\
\hline $\begin{array}{l}\text { Jones, S.J., Mieszkowska, N., Wethey, D.S. (2009). Linking Thermal Tolerances } \\
\text { and Biogeography: Mytilus edulis (L.) at its Southern Limit on the East Coast of } \\
\text { the United States. Biological Bulletin 217, 73-85. }\end{array}$ & $\begin{array}{l}\text { Low quality score to identify risk } \\
\text { factors ( } 1 \text { study) }\end{array}$ \\
\hline $\begin{array}{l}\text { Karagiannis, D., I. N. Vatsos, et al. (2011). Effects of atrazine on the viability and } \\
\text { the formation of byssus of the mussel Mytilus galloprovincialis. Aquaculture }\end{array}$ & $\begin{array}{l}\text { Low field transposition score ( } 2 \\
\text { studies) }\end{array}$ \\
\hline
\end{tabular}




\begin{tabular}{|c|c|}
\hline International 19(1): 103-110. & \\
\hline $\begin{array}{l}\text { Karayucel, S., Celik, M. Y., et al. (2015). Effects of stocking density on survival, } \\
\text { growth and biochemical composition of cultured mussels (Mytilus } \\
\text { galloprovincialis, Lamarck 1819) from an offshore submerged longline system. } \\
\text { Aquaculture Research 46(6): 1369-1383. }\end{array}$ & $\begin{array}{l}\text { Outcome : mortality risk is not the } \\
\text { focus }\end{array}$ \\
\hline $\begin{array}{l}\text { Khalaman, V. V. and Komendantov, A. Y. (2007). Mutual effects of several } \\
\text { fouling organisms of the white sea (Mytilus edulis, Styela rustica, and Hiatella } \\
\text { arctica) on their growth rate and survival. Russian Journal of Marine Biology } \\
\text { 33(3): 139-144. }\end{array}$ & $\begin{array}{l}\text { Exposure: risk factors for mortality not } \\
\text { examined }\end{array}$ \\
\hline $\begin{array}{l}\text { Kock, M., Farre, M., et al. (2010). Integrated ecotoxicological and chemical } \\
\text { approach for the assessment of pesticide pollution in the Ebro River delta } \\
\text { (Spain). Journal of Hydrology } \mathbf{3 8 3}(1-2): 73-82 \text {. }\end{array}$ & $\begin{array}{l}\text { - Outcome : mortality risk is not the } \\
\text { focus } \\
\text { - Exposure: risk factors for mortality } \\
\text { not examined }\end{array}$ \\
\hline $\begin{array}{l}\text { Kristensen, P.S., Lassen, H. (1997). The production of relaid blue mussels } \\
\text { (Mytilus edulis L.) in a Danish fjord. Ices Journal of Marine Science 54, 854-865. }\end{array}$ & $\begin{array}{l}\text { Low quality score to identify risk } \\
\text { factors }\end{array}$ \\
\hline $\begin{array}{l}\text { LeBlanc, N. (2006). Mussel genetics in relation to selection methods for high } \\
\text { quality seed and treatment for tunicates. Dissertation Abstracts International } \\
\text { 68: } 169 \text {. }\end{array}$ & Full text not available \\
\hline $\begin{array}{l}\text { Leblanc, N., Davidson, J., et al. (2006). The effects of anti-fouling treatments for } \\
\text { Styela clava on long-line cultured Mytilus edulis in Prince Edwards Island, } \\
\text { Canada. 98th Annual meeting of the National Shellfisheries Association. } \\
\text { Monterey, California, USA. }\end{array}$ & $\begin{array}{l}\text { Duplicate not detected at the title and } \\
\text { abstract step }\end{array}$ \\
\hline $\begin{array}{l}\text { LeBlanc, N., Davidson, J., et al. (2006). The effects of anti-fouling treatments for } \\
\text { Styela clava on long-line cultured Mytilus edulis in Prince Edward Island, } \\
\text { Canada. Journal of Shellfish Research 25(2): } 748 .\end{array}$ & $\begin{array}{l}\text { Outcome : mortality risk is not the } \\
\text { focus }\end{array}$ \\
\hline $\begin{array}{l}\text { LeBlanc, N., Davidson, J., et al. (2007). The effect of anti-fouling treatments for } \\
\text { the clubbed tunicate on the blue mussel, Mytilus edulis. Aquaculture 264(1-4): } \\
\text { 205-213. }\end{array}$ & $\begin{array}{l}\text { Outcome : mortality risk is not the } \\
\text { focus }\end{array}$ \\
\hline $\begin{array}{l}\text { LeBlanc, N., Landry, T., Davidson, J., Tremblay, R., McNiven, M. (2010). The } \\
\text { effect of elevated water temperature stress on the mussel Mytilus edulis (L.), } \\
\text { survival and genetic characteristics. Canadian Technical Report of Fisheries and } \\
\text { Aquatic Sciences } 2900.19 \text { p. }\end{array}$ & $\begin{array}{l}\text { Low quality score to identify risk } \\
\text { factors ( } 1 \text { study) }\end{array}$ \\
\hline $\begin{array}{l}\text { Lupo, C. and Prou, J. (2016). Enhanced surveillance of mussel mortality to } \\
\text { improve early detection and investigation of outbreaks of infectious diseases. } \\
\text { Annual Meeting of the National Reference Laboratories for Mollusc Diseases, } \\
\text { Nantes, France. }\end{array}$ & $\begin{array}{l}\text { Duplicate not detected at the title and } \\
\text { abstract step }\end{array}$ \\
\hline $\begin{array}{l}\text { Lupo, C. and Prou, J. (2016). Enhanced surveillance of shellfish mortality to } \\
\text { improve early detection and investigation of outbreaks of exotic or emerging } \\
\text { infectious diseases: An example of a mass mortality outbreak of mussels, } \\
\text { France 2014. Preventive Veterinary Medicine 132: 57-66. }\end{array}$ & $\begin{array}{l}\text { Exposure: risk factors for mortality not } \\
\text { examined }\end{array}$ \\
\hline $\begin{array}{l}\text { Maar, M., Timmermann, K., et al. (2010). A model study of the regulation of } \\
\text { blue mussels by nutrient loadings and water column stability in a shallow } \\
\text { estuary, the Limfjorden. Journal of Sea Research } 64(3): 322-333 \text {. }\end{array}$ & $\begin{array}{l}\text { - Outcome : mortality risk is not the } \\
\text { focus } \\
\text { - Exposure: risk factors for mortality } \\
\text { not examined }\end{array}$ \\
\hline $\begin{array}{l}\text { Marcheselli, M., C. Rustichelli, et al. (2010). Novel Antifouling Agent Zinc } \\
\text { Pyrithione: Determination, Acute Toxicity, and Bioaccumulation in Marine } \\
\text { Mussels (Mytilus Galloprovincialis). Environmental Toxicology and Chemistry } \\
\text { 29(11): 2583-2592. }\end{array}$ & $\begin{array}{l}\text { Low field transposition score ( } 2 \\
\text { studies) }\end{array}$ \\
\hline $\begin{array}{l}\text { Marigomez, I., Mugica, M., et al. (2017). Chronic environmental stress enhances } \\
\text { tolerance to seasonal gradual warming in marine mussels. Plos One 12(3). }\end{array}$ & $\begin{array}{l}\text { - Outcome : mortality risk is not the } \\
\text { focus } \\
\text { - Exposure: risk factors for mortality } \\
\text { not examined }\end{array}$ \\
\hline $\begin{array}{l}\text { Marin, M. G., Boscolo, R., et al. (2006). Field validation of autometallographical } \\
\text { black silver deposit (BSD) extent in three bivalve species from the Lagoon of } \\
\text { Venice, Italy (Mytilus galloprovincialis, Tapes philippinarum, Scapharca } \\
\text { inaequivalvis) for metal bioavailability assessment. Sci Total Environ 371(1-3): } \\
\text { 156-167. }\end{array}$ & $\begin{array}{l}\text { - Outcome : mortality risk is not the } \\
\text { focus } \\
\text { - Exposure: risk factors for mortality } \\
\text { not examined }\end{array}$ \\
\hline $\begin{array}{l}\text { Matozzo, V., Ercolini, C., et al. (2018). Assessing the health status of farmed } \\
\text { mussels (Mytilus galloprovincialis) through histological, microbiological and } \\
\text { biomarker analyses. Journal of Invertebrate Pathology 153: 165-179. }\end{array}$ & $\begin{array}{l}\text { Outcome : mortality risk is not the } \\
\text { focus }\end{array}$ \\
\hline $\begin{array}{l}\text { Matozzo, V., Fabrello, J., et al. (2018). Ecotoxicological risk assessment for the } \\
\text { herbicide glyphosate to non-target aquatic species: A case study with the } \\
\text { mussel Mytilus galloprovincialis. Environmental Pollution 233: 623-632. }\end{array}$ & $\begin{array}{l}\text { Outcome : mortality risk is not the } \\
\text { focus }\end{array}$ \\
\hline Meneghetti, F., Moschino, V., et al. (2006). Interaction between mussels & Full text not available \\
\hline
\end{tabular}


(Mytilus galloprovincialis Lmk) and habitat in an experimental area of the North Adriatic Sea: evaluation of biological responses. Biologia marina mediterranea: 703-706.

Mesas, A. and Tarifeno, E. (2015). Upper lethal temperatures for the mussel Mytilus galloprovincialis (Lamarck, 1819), in central coast of Chile. Latin American Journal of Aquatic Research 43(3): 473-483.

Mezzelani, M., Gorbi, S., et al. (2018). Long-term exposure of Mytilus galloprovincialis to diclofenac, Ibuprofen and Ketoprofen: Insights into bioavailability, biomarkers and transcriptomic changes. Chemosphere 198: 238248.

Michaelidis, B., Portner, H. O., et al. (2014). Advances in predicting the impacts of global warming on the mussels Mytilus galloprovincialis in the mediterranean sea. The Mediterranean Sea: Its history and present challenges. S. Goffredo and Z. Dubinsky (eds.), Springer Science+Business Media Dordrecht: 319-339.

Moreira, R., Balseiro, P., et al. (2018). Bivalve transcriptomics reveal pathogen sequences and a powerful immune response of the Mediterranean mussel (Mytilus galloprovincialis). Marine Biology 165(4).

Morello, S. L. and Etter, R. J. (2017). Estimating the impact of consumers in ecological communities: Manual removals identify the complex role of individual consumers in the Gulf of Maine. Journal of Experimental Marine Biology and Ecology 495: 89-102.

Morello, S. L. and Etter, R. J. (2018). Transition probabilities help identify putative drivers of community change in complex systems. Ecology 99(6): 13571369.

Mortensen, S. (2018). Marteilia case in Scandinavia. Annual Meeting of the National Reference Laboratories for Mollusc Diseases. La Rochelle, France. Moschino, V., E. Delaney, et al. (2011). Biomonitoring approach with mussel Mytilus galloprovincialis (Lmk) and clam Ruditapes philippinarum (Adams and Reeve, 1850) in the Lagoon of Venice. Environmental Monitoring and Assessment 177(1-4): 649-663.

Motta, C. M., Tizzano, M., et al. (2018). Biocide triclosan impairs byssus formation in marine mussels Mytilus galloprovincialis. Environmental Pollution 241: 388-396.

Muller, E. B., Hanna, S. K., et al. (2014). Impact of engineered zinc oxide nanoparticles on the energy budgets of Mytilus galloprovincialis. Journal of Sea Research 94: 29-36.

Nesto, N., Romano, S., et al. (2007). Bioaccumulation and biomarker responses of trace metals and micro-organic pollutants in mussels and fish from the Lagoon of Venice, Italy. Marine Pollution Bulletin 55(10-12): 469-484.

Nikiforov, S. M. and Zvyagintsev, A. Y. (2008). Allozyme diversity among local populations of the pacific mussel Mytilus trossulus (Bivalvia : Mytilidae) from polluted areas of Peter the Great Bay (Sea of Japan). Russian Journal of Marine Biology 34(1): 45-50.

Nikolova, G., Karamalakova, Y., et al. (2018). Comparative analysis of real-time oxidative stress biomarkers measured in mussels (Mytilus galloprovincialis) and veined rapa whelks (Rapana venosa) in relation to two seasons - An electron paramagnetic resonance study. Bulgarian Chemical Communications 50(Special Issue C): 58-63.

O'Connor, N. E., Crowe, T. P., et al. (2006). Effects of epibiotic algae on the survival, biomass and recruitment of mussels, Mytilus L. (Bivalvia : Mollusca). Journal of Experimental Marine Biology and Ecology 328(2): 265-276.

Oden, E., E. A. V. Burioli, et al. (2016). Multilocus sequence analysis of Vibrio splendidus related-strains isolated from blue mussel Mytilus sp during mortality events. Aquaculture 464: 420-427.

Passarelli, M. C., I. Riba, et al. (2018). What is the best endpoint for assessing environmental risk associated with acidification caused by $\mathrm{CO} 2$ enrichment using mussels? Marine Pollution Bulletin 128: 379-389.

Peperzak, L. and Poelman, M. (2008). Mass mussel mortality in The Netherlands after a bloom of Phaeocystis globosa (prymnesiophyceae). Journal of Sea Research 60(3): 220-222.

Pépin, J. F., A. Benabdelmouna, et al. (2018). Mortalités de moules bleues dans les secteurs mytilicoles : description et facteurs liés -MORBLEU-,

Document in Spanish

Outcome : mortality risk is not the focus

Study type : review study

Outcome : mortality risk is not the focus

Outcome : mortality risk is not the focus

- Outcome : mortality risk is not the focus

- Exposure: risk factors for mortality not examined

Outcome : mortality risk is not the focus

Low field transposition score

Outcome : mortality risk is not the focus

Outcome : mortality risk is not the focus

- Outcome : mortality risk is not the focus

- Exposure: risk factors for mortality not examined 3

Outcome : mortality risk is not the focus

Outcome : mortality risk is not the focus

Outcome : mortality risk is not the focus

Low field transposition score

Low field transposition score

Exposure: risk factors for mortality not examined

Low field transposition score (1 study) 


\begin{tabular}{|c|c|}
\hline R.INT.RBE/SG2M-LGPMM. & \\
\hline $\begin{array}{l}\text { Pépin, J.F., Benabdelmouna, A., Bierne, N., Bouget, J.F., Chabirand, J.M., Costes, } \\
\text { L., Dégremont, Garcia, C., Génauzeau, S., Geairon, P., Grizon, J., Guesdon, S., } \\
\text { Lamy, J.-B., Ledu, C., Le Jolivet, A., Le Moine, O., Le Noc, S., Morga, B., } \\
\text { Normand, J., Palvadeau, H., Polsenaere, P., Robert, S., Saunier, A., Schmitt, A., } \\
\text { Seugnet, J.L., Tourbiez, D., Travers, M.A. (2017). Mortalités de moules bleues } \\
\text { dans les secteurs mytilicoles charentais et vendéens : description et facteurs } \\
\text { liés -MORBLEU-. R.INT.RBE/SG2M-LGPMM. } \\
\text { https://archimer.ifremer.fr/doc/00391/50288/ }\end{array}$ & $\begin{array}{l}\text { Low quality score to identify risk } \\
\text { factors ( } 1 \text { study) }\end{array}$ \\
\hline $\begin{array}{l}\text { Petes, L. E. (2007). Effects of environmental stress on intertidal mussel } \\
\text { reproduction. Dissertation Abstracts International 68(no. 06, suppl. B): } 196 .\end{array}$ & $\begin{array}{l}\text { Duplicate not detected at the title and } \\
\text { abstract step }\end{array}$ \\
\hline $\begin{array}{l}\text { Petes, L. E., Menge, B. A., et al. (2007). Environmental stress decreases survival, } \\
\text { growth, and reproduction in New Zealand mussels. Journal of Experimental } \\
\text { Marine Biology and Ecology 351(1-2): 83-91. }\end{array}$ & $\begin{array}{l}\text { - Outcome : mortality risk is not the } \\
\text { focus } \\
\text { - Exposure: risk factors for mortality } \\
\text { not examined }\end{array}$ \\
\hline $\begin{array}{l}\text { Polsenaere, P., Soletchnik, P., et al. (2017). Potential environmental drivers of a } \\
\text { regional blue mussel mass mortality event (winter of 2014, Breton Sound, } \\
\text { France). Journal of Sea Research 123: 39-50. }\end{array}$ & $\begin{array}{l}\text { Exposure: risk factors for mortality not } \\
\text { examined }\end{array}$ \\
\hline $\begin{array}{l}\text { Quaglio, F., Quaglieri, E., et al. (2017). Histological and microbiological } \\
\text { investigations in farmed mussels (Mytilus galloprovincialis) of La Spezia Gulf, } \\
\text { Italy to evaluate health status. 18th International Conference on Diseases of } \\
\text { Fish and Shellfish, Belfast, United-Kingdom. }\end{array}$ & $\begin{array}{l}\text { Outcome : mortality risk is not the } \\
\text { focus }\end{array}$ \\
\hline $\begin{array}{l}\text { Renault, T. (2011). BIVALIFE, a FP7 project focusing on the management of } \\
\text { infectious diseases affecting oysters and mussels. Annual Meeting of the } \\
\text { National Reference Laboratories for Mollusc Diseases, La Rochelle, France. }\end{array}$ & $\begin{array}{l}\text { Duplicate not detected at the title and } \\
\text { abstract step }\end{array}$ \\
\hline $\begin{array}{l}\text { Renault, T. (2014). BIVALIFE - Controlling infectious diseases in oysters and } \\
\text { mussels in Europe - Periodic Report. 266157_BIVALIFE_Periodic_Report- } \\
\text { 12_20140428_192012_CET. }\end{array}$ & $\begin{array}{l}\text { Low quality score to identify risk } \\
\text { factors ( } 2 \text { studies) }\end{array}$ \\
\hline $\begin{array}{l}\text { Rius, M. and McQuaid, C. D. (2006). Wave action and competitive interaction } \\
\text { between the invasive mussel Mytilus galloprovincialis and the indigenous Perna } \\
\text { perna in South Africa. Marine Biology 150(1): } 69-78 \text {. }\end{array}$ & $\begin{array}{l}\text { Exposure: risk factors for mortality not } \\
\text { examined }\end{array}$ \\
\hline $\begin{array}{l}\text { Romero, A., M. D. Costa, et al. (2014). Occurrence, seasonality and infectivity of } \\
\text { Vibrio strains in natural populations of mussels Mytilus galloprovincialis. } \\
\text { Diseases of Aquatic Organisms 108(2): 149-163. }\end{array}$ & $\begin{array}{l}\text { Low field transposition score ( } 2 \\
\text { studies) }\end{array}$ \\
\hline $\begin{array}{l}\text { Rosioru, D. M. (2014). Ecological resilience of Mytilus galloprovincialis from the } \\
\text { Romanian Black Sea coast at environmental variations. Journal of } \\
\text { Environmental Protection and Ecology 15(3): 924-932. }\end{array}$ & $\begin{array}{l}\text { Low field transposition score ( } 2 \\
\text { studies) }\end{array}$ \\
\hline $\begin{array}{l}\text { Rowley, A. F., Cross, M. E., et al. (2014). The potential impact of climate change } \\
\text { on the infectious diseases of commercially important shellfish populations in } \\
\text { the Irish Sea-a review. Ices Journal of Marine Science 71(4): 741-759. }\end{array}$ & $\begin{array}{l}\text { - Study type : review study } \\
\text { - Outcome : mortality risk is not the } \\
\text { focus }\end{array}$ \\
\hline $\begin{array}{l}\text { Ruellet, T., Meirland, A. (2010). Evaluation des pertes mytilicoles du secteur de } \\
\text { Quend-Plage les Pins et de Saint-Quentin-en-Tourmont au cours du mois de mai } \\
\text { 2010. Saint Valery sur Somme, GEMEL, } 8 \text { p. }\end{array}$ & $\begin{array}{l}\text { Low quality score to identify risk } \\
\text { factors }\end{array}$ \\
\hline $\begin{array}{l}\text { Sandee, S. D., Van Hamme, J. D., et al. (2016). Testing microbial pathogens as a } \\
\text { cause of early juvenile mortality in wild populations of benthic invertebrates. } \\
\text { Marine Ecology Progress Series 562: 53-63. }\end{array}$ & Population : larvae stage studied \\
\hline $\begin{array}{l}\text { Schneider, K.R., Van Thiel, L.E., Helmuth, B. (2010). Interactive effects of food } \\
\text { availability and aerial body temperature on the survival of two intertidal } \\
\text { Mytilus species. Journal of Thermal Biology 35, 161-166. }\end{array}$ & $\begin{array}{l}\text { Low quality score to identify risk } \\
\text { factors }\end{array}$ \\
\hline $\begin{array}{l}\text { Scro, A. K., Materna, C., et al. (2016). The occurrence and severity of disease in } \\
\text { populations of blue mussels, Mytilus edulis, in Rhode Island coastal waters. } \\
\text { Aquaculture, Las Vegas, Nevada, USA. }\end{array}$ & $\begin{array}{l}\text { Absence of result in this conference } \\
\text { proceedings }\end{array}$ \\
\hline $\begin{array}{l}\text { Serracca, L., Prearo, M., et al. (2014). Four-Year Surveillance of Marteilia } \\
\text { refringens in Shellfish Farms in the Gulf of La Spezia (Liguria, Italy). Turkish } \\
\text { Journal of Fisheries and Aquatic Sciences 14(4): 893-896. }\end{array}$ & $\begin{array}{l}\text { Outcome : mortality risk is not the } \\
\text { focus }\end{array}$ \\
\hline $\begin{array}{l}\text { Sforzini, S., Oliveri, C., et al. (2018). Application of a new targeted low density } \\
\text { microarray and conventional biomarkers to evaluate the health status of } \\
\text { marine mussels: A field study in Sardinian coast, Italy. Science of the Total } \\
\text { Environment 628-629: 319-328. }\end{array}$ & $\begin{array}{l}\text { Outcome : mortality risk is not the } \\
\text { focus }\end{array}$ \\
\hline SMEL-LABEO (2016). Programme CACHEMYRE. CRC Normandie-Mer du Nord. & $\begin{array}{l}\text { Outcome : mortality risk is not the } \\
\text { focus }\end{array}$ \\
\hline $\begin{array}{l}\text { SMIDAP (2017). Programme CAPEMOULES } 2 \text { Bis. SMIDAP \& CRC Pays de la } \\
\text { Loire. }\end{array}$ & $\begin{array}{l}\text { Duplicate not detected at the title and } \\
\text { abstract step }\end{array}$ \\
\hline
\end{tabular}


Soletchnik, P. and Robert, S. (2016). Eléments de connaissance sur la mortalité et la reproduction de la moule bleue (Mytilus edulis) sur la façade atlantique, RST/ ODE / LER / LERPC - juillet 2016.

https://archimer.ifremer.fr/doc/00345/45634/

Steeves, L. E., Filgueira, R. n., et al. (2018). Past, Present, and Future:

Performance of Two Bivalve Species Under Changing Environmental Conditions.

Frontiers in Marine Science 5(184).

Sundt, R. C., Pampanin, D. M., et al. (2006). The BEEP Stavanger Workshop:

Mesocosm exposures. Aquatic Toxicology 78: S5-S12.

Theodorou, J. A., Tzovenis, I., et al. (2015). Risk analysis of the Mediterranean

mussel farming in Greece. European Aquaculture Society Conference,

Rotterdam, The Netherlands.

Travers, M.-A., B. Morga, et al. (2015). Pathogens detected during mortality

events of mussels in France in 2014. Annual meeting of NRLs for Mollusc

diseases and the technical workshop, Saintes, France.

Travers, M.-A., Morga, B., et al. (2015). Pathogens detected during mortality

events of mussels in France in 2014. Annual meeting of NRLs for Mollusc

diseases and the technical workshop, Saintes, France.

Vlahogianni, T. H. and A. Valavanidis (2007). Heavy-metal effects on lipid peroxidation and antioxidant defence enzymes in mussels Mytilus

galloprovincialis. Chemistry and Ecology 23(5): 361-371.

Wepener, V., Bervoets, L., et al. (2008). Metal exposure and biological

responses in resident and transplanted blue mussels (Mytilus edulis) from the

Scheldt estuary. Marine Pollution Bulletin 57(6-12): 624-631.

Wethey, D. S., Woodin, S. A., et al. (2011). Response of intertidal populations to

climate: Effects of extreme events versus long term change. Journal of

Experimental Marine Biology and Ecology 400(1-2): 132-144.

Wu, H. F., Ji, C. L., et al. (2013). Proteomic and metabolomic responses in hepatopancreas of Mytilus galloprovincialis challenged by Micrococcus luteus and Vibrio anguillarum. Journal of Proteomics 94: 54-67.

Yanick, J. F., J. W. Heath, et al. (2003). Survival and growth of local and transplanted blue mussels (Mytilus trossulus, Lamark). Aquaculture Research 34(10): 869-875.

Zardi, G. I., K. R. Nicastro, et al. (2006). Sand stress as a non-determinant of habitat segregation of indigenous (Perna perna) and invasive (Mytilus galloprovincialis) mussels in South Africa. Marine Biology 148(5): 1031-1038.
Exposure: risk factors for mortality not examined

Outcome : mortality risk is not the

focus

- Outcome : mortality risk is not the

focus

- Exposure: risk factors for mortality not examined

Full text not available

Low field transposition score

Duplicate not detected at the title and abstract step

Low field transposition score

Exposure: risk factors for mortality not

examined

Outcome : mortality risk is not the

focus

Outcome : mortality risk is not the

focus

Low field transposition score

Low field transposition score (1 study) 
Appendix III. Table synthetizing key results of the 114 studies included in the narrative synthesis

\begin{tabular}{|c|c|c|c|c|c|c|c|c|c|}
\hline Study ID & Reference & Country & Mussel species & $\begin{array}{c}\text { Study } \\
\text { conditions }\end{array}$ & $\begin{array}{l}\text { Methodolog } \\
\text { ical quality } \\
\text { score }\end{array}$ & Risk factor topic(s) & Risk factor(s) studied & $\begin{array}{l}\text { Interactio } \\
\text { ns } \\
\text { accounte } \\
\text { d }\end{array}$ & Key results \\
\hline 177 & $\begin{array}{l}\text { Dionne et al. } \\
\text { (2006) }\end{array}$ & Canada & Mytilus edulis & Observation & High & $\begin{array}{l}\text {-Animal characteristics, } \\
\text {-Site characteristics, } \\
\text {-Husbandry/fishery practices }\end{array}$ & $\begin{array}{l}\text {-Mussel size } \\
\text {-Predation by diving ducks } \\
\text {-Protective socking material }\end{array}$ & Yes & $\begin{array}{l}\text { mortality by predation decreases with the use of } \\
\text { tighter mesh socks (against ducks), especially in } \\
\text { large mussels }\end{array}$ \\
\hline 323 & $\begin{array}{l}\text { Penney et al. } \\
\text { (2006) }\end{array}$ & Canada & Mytilus edulis & Observation & High & $\begin{array}{l}\text {-Animal characteristics } \\
\text {-Site characteristics } \\
\text {-Husbandry/fishery practices }\end{array}$ & $\begin{array}{l}\text {-Genotypes (M. edulis, M. trossulus } \\
\text { and hybrids) } \\
\text {-Farming site } \\
\text {-Spat translocation }\end{array}$ & Yes & $\begin{array}{l}\text { - initial genetic heterogeneity between the } 2 \text { sites } \\
\text { - no effect of the proportion of different species on } \\
\text { mortality } \\
\text { - site effect on mortality of different genotypes } \\
\text { - transplanted mussels: mortality } M \text {. trossulus }>M \text {. } \\
\text { edulis or hybrids } \\
\text { - conclusion: interaction of site and genotype } \\
\text { effects on mortality } \\
\text { - at one of the } 2 \text { sites: local spat mortality higher } \\
\text { than transplanted spat mortality }\end{array}$ \\
\hline 1098 & Lok et al. (2007) & Turkey & $\begin{array}{c}\text { Mytilus } \\
\text { galloprovincialis }\end{array}$ & Observation & Moderate & Animal characteristics & -Initial size of seed ( 7 classes) & No & $\begin{array}{l}\text {-mortality }<5 \% \text { in each class } \\
\text {-no effect of mussel size on low mortality levels }\end{array}$ \\
\hline 1118 & Suni et al. (2007) & Finland & Mytilus edulis & Laboratory & Moderate & Pollutants & -Diesel oil & No & $\begin{array}{l}\text {-exposure to diesel oil associated with } 100 \% \\
\text { mortality } \\
\text { - exposure to diesel oil + its removal by cotton } \\
\text { fibres does not cause mortality but histological } \\
\text { lesions (inflammation, degeneration, cell death) }\end{array}$ \\
\hline 1159 & $\begin{array}{l}\text { Ramon et al. } \\
(2007)\end{array}$ & Spain & $\begin{array}{c}\text { Mytilus } \\
\text { galloprovincialis }\end{array}$ & Observation & Moderate & Husbandry/fishery practices & -Spat origin & No & $\begin{array}{l}\text { effect of spat origin on mortality in August: local } \\
\text { spat mortality < transplanted spat }\end{array}$ \\
\hline 1204 & $\begin{array}{l}\text { Anestis et al. } \\
\text { (2007) }\end{array}$ & Greece & $\begin{array}{c}\text { Mytilus } \\
\text { galloprovincialis }\end{array}$ & Laboratory & Moderate & Seawater characteristics & -Seawater temperature & No & $\begin{array}{l}\text { - mussel mortality observed if water temperature }> \\
26^{\circ} \mathrm{C} \\
\text { - if seawater temperature }>26^{\circ} \mathrm{C} \text {, mortality } \\
\text { increases with increasing temperature }\end{array}$ \\
\hline 1717 & $\begin{array}{l}\text { Rosen \& Lotufo } \\
(2007)\end{array}$ & $\begin{array}{l}\text { United } \\
\text { States of } \\
\text { America }\end{array}$ & $\begin{array}{c}\text { Mytilus } \\
\text { galloprovincialis }\end{array}$ & Laboratory & Moderate & Pollutants & $\begin{array}{l}\text { Explosive compounds: } \\
\text {-TNT: 2,4,6-trinitrotoluene } \\
\text {-RDX: hexahydro-1,3,5, -triazine } \\
\text {-HMX: octahydro-1,3,5,7-tetranitro- } \\
\text { 1,3,5,7-tetrazocine }\end{array}$ & No & $\begin{array}{l}\text { - no lethal effect with } \mathrm{RDX}<30 \mathrm{mg} / \mathrm{L}- \\
\text { - no lethal effect with } \mathrm{HMX}<2 \mathrm{mg} / \mathrm{L}- \\
-89 \% \text { mortality if TNT }=30 \mathrm{mg} / \mathrm{L}\end{array}$ \\
\hline 2303 & $\begin{array}{l}\text { Schields et al. } \\
\text { (2008) }\end{array}$ & Canada & $\begin{array}{c}\text { Mytilus } \\
\text { galloprovincialis }\end{array}$ & Observation & High & $\begin{array}{l}\text {-Animal characteristics } \\
\text {-Husbandry/fishery practices }\end{array}$ & $\begin{array}{l}\text {-Genotype of mussels ( } M . \\
\text { galloprovincialis, M. edulis, } M . \\
\text { trossulus) } \\
\text {-Site: native vs. transplanted } \\
\text { (characterized by different } \\
\text { seawater temperatures) }\end{array}$ & No & $\begin{array}{l}\text { - site effect: mortality on transplanted site < } \\
\text { mortality on native site } \\
\text { - no difference in mortality between native ( } M \text {. } \\
\text { trossulus) / hybrids / introduced ( } M \text {. } \\
\text { galloprovincialis) genotypes } \\
\text { - no difference in mortality between intrasite } \\
\text { genotypes }\end{array}$ \\
\hline 2493 & $\begin{array}{l}\text { LeBlanc et al. } \\
\text { (2008) }\end{array}$ & Canada & Mytilus edulis & Observation & High & Husbandry/fishery practices & $\begin{array}{l}\text {-Exposure to high air temperature } \\
\left(27.2^{\circ} \mathrm{C}+/-0.5 \text { for } 11 \text { hours) before }\right. \\
\text { deployment in the field } \\
\text {-Exposure to high water } \\
\text { temperature }\left(32.6^{\circ} \mathrm{C} \text { for } 6 \text { hours }\right) \\
\text { before deployment in the field }\end{array}$ & No & $\begin{array}{l}\text {-treatment of mussels with high seawater } \\
\text { temperature or high aerial temperature at the } \\
<10 \mathrm{~mm} \text { stage before field deployment reduces } \\
\text { mortality } \\
\text { - higher degree of heterozygosity in surviving } \\
\text { mussels from mortality events }\end{array}$ \\
\hline
\end{tabular}




\begin{tabular}{|c|c|c|c|c|c|c|c|c|c|}
\hline 2684 & $\begin{array}{l}\text { Nicastro et al. } \\
\text { (2008) }\end{array}$ & South Africa & $\begin{array}{c}\text { Mytilus } \\
\text { galloprovincialis }\end{array}$ & Observation & Moderate & $\begin{array}{l}\text {-Site characteristics } \\
\text {-Climate characteristics }\end{array}$ & $\begin{array}{l}\text {-Position in the bed: centre vs. edge } \\
\text {-Bay vs. open coast habitat } \\
\text {-Season }\end{array}$ & No & $\begin{array}{l}\text {-mortality on the open coast > mortality in the bay } \\
\text {-difference not significant between mortality at the } \\
\text { edge of beds or at the centre } \\
\text {-\% mussel movement correlated to \% mortality of } \\
\text { the previous month } \\
\text {-seasonality of mortality : higher mortality at the } \\
\text { end of summer } \\
\text { Explanation of the authors: the observed mortality } \\
\text { is due to hydrodynamic stress, which is higher on } \\
\text { the coast than in the bay, and also higher at the } \\
\text { edge of the bed than in the centre. After a mortality } \\
\text { event, the mussels move to reorganize the bed into } \\
\text { a safer arrangement. }\end{array}$ \\
\hline 2698 & $\begin{array}{l}\text { Zardi et al. } \\
\text { (2008) }\end{array}$ & South Africa & $\begin{array}{c}\text { Mytilus } \\
\text { galloprovincialis }\end{array}$ & Observation & High & Site characteristics & $\begin{array}{l}\text {-Wave height } \\
\text {-Sediment amount }\end{array}$ & No & $\begin{array}{l}\text { - mortality increases with wave height increasing } \\
\text {-absence of effect of sediment amount on mortality }\end{array}$ \\
\hline 2800 & $\begin{array}{l}\text { Babarro \& De } \\
\text { Zwaan (2008) }\end{array}$ & $\begin{array}{l}\text { The } \\
\text { Netherlands }\end{array}$ & Mytilus edulis & Laboratory & Moderate & Pathogens & -Anaerobic bacteria & No & $\begin{array}{l}-3 \text { anoxic conditions, obtained from } 3 \text { different } \\
\text { methods: no difference in survival between } \\
\text { anoxic/air and nitrogen EDM conditions } \\
\text {-so not a real study of the effect of the risk factor } \\
\text { 'anoxia' } \\
\text { - effect of acclimatization with chloramphenicol: } \\
\text { increased survival (X2) } \\
\text { Explanation of the authors: importance of } \\
\text { anaerobic bacteria as a risk factor of mortality? }\end{array}$ \\
\hline 3874 & $\begin{array}{l}\text { Anestis et al. } \\
\text { (2010) }\end{array}$ & Greece & $\begin{array}{c}\text { Mytilus } \\
\text { galloprovincialis }\end{array}$ & Laboratory & Moderate & Climate characteristics & $\begin{array}{l}\text { Range between air and seawater } \\
\text { temperature }\end{array}$ & No & $\begin{array}{l}\text {-exposure to air temperature }>\text { water temperature } \\
\text { => mortality } \\
\text { - mortality increases if the temperature range } \\
\text { between water and air increases }\end{array}$ \\
\hline 3960 & $\begin{array}{l}\text { Ali \& Taylor } \\
\text { (2010) }\end{array}$ & $\begin{array}{l}\text { United } \\
\text { Kingdom }\end{array}$ & Mytilus edulis & Laboratory & Moderate & $\begin{array}{l}\text {-Seawater characteristics } \\
\text {-Pollutants }\end{array}$ & $\begin{array}{l}\text {-Seawater temperature } \\
\text {-Salinity } \\
\text {-Zinc } \\
\text {-Cadmium }\end{array}$ & Yes & $\begin{array}{l}\text { - mortality with low salinity ( } 20 \mathrm{psu}) \\
\text { - low salinity: mortality } \mathrm{Cd}>\text { mortality } \mathrm{Zn} \\
\text { - absence of effect of seawater temperature on } \\
\text { mortality } \\
\text { - significant interaction between low salinity \& high } \\
\text { seawater temperature }\end{array}$ \\
\hline 4172 & $\begin{array}{l}\text { Bownes \& } \\
\text { McQuaid (2010) }\end{array}$ & South Africa & $\begin{array}{c}\text { Mytilus } \\
\text { galloprovincialis }\end{array}$ & Observation & High & Site characteristics & $\begin{array}{l}\text { - Site effect } \\
\text { - Location effect on the site } \\
\text { - Height on the shore }\end{array}$ & Yes & $\begin{array}{l}\text { - mortality M. galloprovincialis : } \\
\text { - site-dependent } \\
\text { - no location effect } \\
\text { - no effect of the height on the shore }\end{array}$ \\
\hline 4367 & $\begin{array}{l}\text { Nicastro et al. } \\
\text { (2010) }\end{array}$ & South Africa & $\begin{array}{c}\text { Mytilus } \\
\text { galloprovincialis }\end{array}$ & Observation & Moderate & $\begin{array}{l}\text { Site characteristics, } \\
\text { Climate characteristics }\end{array}$ & $\begin{array}{l}\text { - Bay vs. open coast habitat } \\
\text { - Wave height } \\
\text { - Sand depth } \\
\text { - Season }\end{array}$ & No & $\begin{array}{l}\text { - in general: coastal mortality > bay mortality except } \\
\text { in June (winter) } \\
\text { - mortality increases with increasing sand depth, } \\
\text { notably in bays } \\
\text { - wave height effect: no correlation between } \% \\
\text { coastal mortality and wave height; correlation } \\
\text { between \% mortality in bays in the previous month } \\
\text { and wave height } \\
\text { - coast : higher mortality in winter-spring (June- } \\
\text { October) / bay : } 2 \text { mortality peaks in summer } \\
\text { (February) and winter (June) }\end{array}$ \\
\hline 4409 & $\begin{array}{l}\text { Plass-Jonhson et } \\
\text { al. (2010) }\end{array}$ & South Africa & $\begin{array}{c}\text { Mytilus } \\
\text { galloprovincialis }\end{array}$ & Observation & High & Site characteristics & -Benthic and pelagic predation & No & $\begin{array}{l}\text { differences in survival between cage types, which } \\
\text { protect against benthic and/or pelagic predation }\end{array}$ \\
\hline
\end{tabular}




\begin{tabular}{|c|c|c|c|c|c|c|c|c|c|}
\hline 4680 & $\begin{array}{l}\text { Jones et al. } \\
\text { (2010) }\end{array}$ & $\begin{array}{l}\text { United } \\
\text { States of } \\
\text { America }\end{array}$ & Mytilus edulis & Observation & Moderate & $\begin{array}{l}\text {-Seawater characteristics } \\
\text {-Climate characteristics }\end{array}$ & $\begin{array}{l}\text { - Seawater temperature } \\
\text { - Air temperature }\end{array}$ & No & $\begin{array}{l}\text {-multiple exposure to air temperatures }>32^{\circ} \mathrm{C} \\
\text { appears to be followed by significant mortality - } \\
\text { average air or water temperature are the best } \\
\text { predictors of mortality ( } \mathrm{R}^{2}=0.89 \text { or } 0.98 \text { depending } \\
\text { on the site) }\end{array}$ \\
\hline 5066 & $\begin{array}{l}\text { Paetzold \& } \\
\text { Davidson (2011) }\end{array}$ & Canada & Mytilus edulis & Laboratory & Moderate & Husbandry/fishery practices & $\begin{array}{l}\text { A1ntifouling disinfectant (Virkon } \odot \\
\text { containing potassium hydrogen } \\
\text { sulphate, sodium dodecyl- } \\
\text { benzenesulphonate, sulphamic acid } \\
\text { and inorganic buffers) }\end{array}$ & No & $\begin{array}{l}\text { - absence of effect of Virkon disinfectant at doses } \\
\text { tested on mussel mortality }\end{array}$ \\
\hline 5373 & $\begin{array}{l}\text { Danellakis et al. } \\
\text { (2011) }\end{array}$ & Greece & $\begin{array}{c}\text { Mytilus } \\
\text { galloprovincialis }\end{array}$ & Laboratory & High & Pollutants & Olive oil mill wastewater & No & $\begin{array}{l}\text { olive oil press waste water }=>\text { mortality at } \\
\text { concentrations of } 1 \text { and } 0.2 \% \mathrm{v} / \mathrm{v}\end{array}$ \\
\hline 6141 & $\begin{array}{l}\text { Tsarpali \& } \\
\text { Dailianis (2012) }\end{array}$ & Greece & $\begin{array}{c}\text { Mytilus } \\
\text { galloprovincialis }\end{array}$ & Laboratory & Moderate & Pollutants & $\begin{array}{l}\text { Leachate (= liquid effluent from } \\
\text { waste by fermentation / rainwater) }\end{array}$ & No & $\begin{array}{l}\text { mussel mortality increases from leachate } \\
\text { concentrations }>0.5 \%\end{array}$ \\
\hline 6756 & Gardner (2013) & $\begin{array}{l}\text { New } \\
\text { Zealand }\end{array}$ & $\begin{array}{c}\text { Mytilus } \\
\text { galloprovincialis }\end{array}$ & Observation & Moderate & $\begin{array}{l}\text {-Site characteristics } \\
\text {-Husbandry/fishery practices }\end{array}$ & $\begin{array}{l}\text {-Site }(\mathrm{n}=3) \\
\text {-Site: } \text { native vs. transplanted }\end{array}$ & No & $\begin{array}{l}\text {-site-dependent mortality } \\
\text {-mortality transplanted site > native site }\end{array}$ \\
\hline 7240 & $\begin{array}{l}\text { Dowd \& Somero } \\
\text { (2013) }\end{array}$ & $\begin{array}{l}\text { United } \\
\text { States of } \\
\text { America }\end{array}$ & $\begin{array}{c}\text { Mytilus } \\
\text { galloprovincialis }\end{array}$ & Laboratory & High & $\begin{array}{l}\text {-Animal characteristics } \\
\text {-Seawater characteristics } \\
\text {-Climate characteristics }\end{array}$ & $\begin{array}{l}\text {-Mussel species (M. } \\
\text { galloprovinciallis vs. M. trossulus vs. } \\
\text { M. californianus) } \\
\text {-Seawater temperature } \\
\text {-Air vs. seawater thermal range } \\
\text {-Number of repetitions of aerial } \\
\text { thermal stress }\end{array}$ & No & $\begin{array}{l}\text {-mortality species } M \text {. trossulus }>M \text {. } \\
\text { galloprovincialis }>M \text {. californianus } \\
\text {-effect on mortality of an increase in seawater } \\
\text { temperature from } 13 \text { to } 33^{\circ} \mathrm{C} \\
\text {-no effect of repeated }(x 3) \text { aerial heat stress on } \\
\text { mortality }\end{array}$ \\
\hline 7454 & $\begin{array}{l}\text { Marquet et al. } \\
\text { (2013) }\end{array}$ & $\begin{array}{l}\text { Portugal \& } \\
\text { South Africa }\end{array}$ & $\begin{array}{c}\text { Mytilus } \\
\text { galloprovincialis }\end{array}$ & Observation & High & $\begin{array}{l}\text {-Pathogens } \\
\text {-Site characteristics }\end{array}$ & $\begin{array}{l}\text {-Endolithic infestation } \\
\text {-Height on the shore }\end{array}$ & Yes & $\begin{array}{l}\text {-absence of effect of shore height on endolith } \\
\text { mortality } \\
\text {-endolith mortality is higher in the invaded } \\
\text { environment (South Africa) than in the native } \\
\text { environment (Portugal) }\end{array}$ \\
\hline 7718 & $\begin{array}{l}\text { Hiebenthal et al. } \\
\text { (2013) }\end{array}$ & Germany & Mytilus edulis & Laboratory & Moderate & $\begin{array}{l}\text {-Animal characteristics } \\
\text {-Seawater characteristics }\end{array}$ & $\begin{array}{l}\text {-Growth } \\
\text {-Condition index } \\
\text {-Lipofuscin accumulation } \\
\text {-Shell resistance } \\
\text {-Seawater temperature }\end{array}$ & No & $\begin{array}{l}\text {-mortality increases with temperature between } 20 \\
\text { and } 25^{\circ} \mathrm{C} \\
\text {-mortality increases with decrease in growth } \\
\text {-mortality increases with decrease in condition } \\
\text { index } \\
\text {-no association with the force required to break the } \\
\text { shell } \\
\text {-mortality increases with increase in lipofuscin } \\
\text { accumulation }\end{array}$ \\
\hline 7791 & $\begin{array}{l}\text { Gazeau et al. } \\
\text { (2018) }\end{array}$ & Spain & $\begin{array}{c}\text { Mytilus } \\
\text { galloprovincialis }\end{array}$ & Laboratory & High & Seawater characteristics & $\begin{array}{l}\text {-Seawater temperature } \\
\text {-Seawater } \mathrm{pH}\end{array}$ & Yes & $\begin{array}{l}\text {-no effect of } \mathrm{pH} \text { decrease } \\
\text {-mortality increases if temperature }>25^{\circ} \mathrm{C}\end{array}$ \\
\hline 9018 & $\begin{array}{l}\text { Tsarpali et al. } \\
\text { (2015) }\end{array}$ & Greece & $\begin{array}{c}\text { Mytilus } \\
\text { galloprovincialis }\end{array}$ & Laboratory & Moderate & Pollutants & $\begin{array}{l}\text {-imidazolium ionic liquids: } \\
.1 \text {-butyl-3-methylimidazolium } \\
\text { tetrafluoroborate } \\
.1 \text {-methyl-3-octylimidazolium } \\
\text { tetrafluoroborate }\end{array}$ & No & $\begin{array}{l}\text {-imidazolium ionic liquids have toxic effects on } \\
\text { mussels (mortality but not only) } \\
\text { - } 1 \text {-butyl-3-methylimidazolium tetrafluoroborate => } \\
\text { mortality if concentration }>10 \mathrm{mg} / \mathrm{L}: \mathrm{LC} 50=128.3 \\
\mathrm{mg} / \mathrm{L}(\mathrm{IC} 95 \%: 45.5-253.5) \text { without acetone and } \\
\mathrm{LC} 50=73.6 \mathrm{mg} / \mathrm{L}(20-3263) \text { with acetone } \\
\text { - 1-methyl-3-octylimidazolium tetrafluoroborate }=> \\
\mathrm{mortality} \text { if concentration }>0.5 \mathrm{mg} / \mathrm{L}: \mathrm{LC} 50=0.512 \\
\mathrm{mg} / \mathrm{L}(0.33-0.63) \text { without acetone and } \mathrm{LC} 50=2.31 \\
\mathrm{mg} / \mathrm{L}(0.67-7.05) \text { with acetone }\end{array}$ \\
\hline 9560 & $\begin{array}{l}\text { Waser et al. } \\
\text { (2015) }\end{array}$ & $\begin{array}{l}\text { The } \\
\text { Netherlands }\end{array}$ & Mytilus edulis & Laboratory & High & Site characteristics & $\begin{array}{l}\text {-Predation by the crab Carcinus } \\
\text { maenas } \\
\text {-Presence of the } \\
\text { oyster Crassostrea gigas }\end{array}$ & Yes & $\begin{array}{l}\text {-presence of oysters reduces mussel mortality } \\
\text {-greater effect if the crab is small } \\
\text {-greater effect if the mussel is small }\end{array}$ \\
\hline
\end{tabular}




\begin{tabular}{|c|c|c|c|c|c|c|c|c|c|}
\hline 10039 & $\begin{array}{l}\text { Gestoso et al. } \\
\text { (2016) }\end{array}$ & Spain & $\begin{array}{c}\text { Mytilus } \\
\text { galloprovincialis }\end{array}$ & Laboratory & High & $\begin{array}{l}\text {-Seawater characteristics } \\
\text {-Husbandry/fishery practices }\end{array}$ & $\begin{array}{l}\text {-Seawater temperature } \\
\text {-Seawater } \mathrm{pH} \\
\text {-Mixed mussel species }\end{array}$ & Yes & $\begin{array}{l}\text {-pH effect: higher mortality if } \mathrm{pH}=7.65 \\
\text {-pH effect decreases if species mixture } \\
\text {-no seawater temperature effect } \\
\text {-type of assembly effect: more mortality if } \\
\text { monospecific assembly }\end{array}$ \\
\hline 10084 & $\begin{array}{l}\text { Barrento \& } \\
\text { Powell (2016) }\end{array}$ & $\begin{array}{l}\text { United } \\
\text { Kingdom }\end{array}$ & Mytilus edulis & Observation & High & Husbandry/fishery practices & $\begin{array}{l}\text { - } 48 \mathrm{H} \text { depuration or } 48 \mathrm{H} \text { emersion } \\
\text { storage on ice before transport } \\
\text {-temperature during transport: } 0^{\circ} \mathrm{C} \\
\text { vs. } 5^{\circ} \mathrm{C} \\
\text {-humidity during transport } \\
\text {-re-soaking time: } 24 \mathrm{H} \text { vs. } 1 \mathrm{H} \\
\text {-re-soaking temperature: } 5 \text { vs. } 10^{\circ} \mathrm{C}\end{array}$ & Yes & $\begin{array}{l}-2 \text { to } 7 \% \text { mortality throughout the transport chain } \\
\text {-not significant difference of mortality in the } \\
\text { absence of depuration before transport vs. with } \\
\text { depuration during } 48 \mathrm{H} \\
\text { - mortality after transport: no effect of depuration } \\
\text { (depuration or storage on ice) or transport } \\
\text { (humidity or temperature) conditions } \\
\text {-re-soaking: mortality of the condition without } \\
\text { depuration and ambient temperature > mortality } \\
\text { of the depuration and ice condition }\end{array}$ \\
\hline 10215 & $\begin{array}{l}\text { Olabarrial et al. } \\
\text { (2016) }\end{array}$ & Spain & $\begin{array}{c}\text { Mytilus } \\
\text { galloprovincialis }\end{array}$ & Laboratory & High & $\begin{array}{l}\text { - Husbandry/fishery practices } \\
\text {-Climate characteristics }\end{array}$ & $\begin{array}{l}\text {-Air temperature } \\
\text {-Mixed mussel species }\end{array}$ & No & $\begin{array}{l}\text {-higher mortality if air temperature is high } \\
-M \text {. galloprovincialis mortality: monospecific } \\
\text { aggregation }>\text { if mixed species }\end{array}$ \\
\hline 10226 & $\begin{array}{l}\text { Gammoudi et al. } \\
\text { (2017) }\end{array}$ & Tunisia & $\begin{array}{c}\text { Mytilus } \\
\text { galloprovincialis }\end{array}$ & Observation & Moderate & Site characteristics & $\begin{array}{l}\text {-Predation by plathelminth } \\
\text { (flatworm) polyclade Imogine } \\
\text { mediterranea }\end{array}$ & No & $\begin{array}{l}\text {-median exposure time resulting in } 50 \% \text { mortality = } \\
4.5 \text { days (CI95\% 2.7-8.9) (median of the } 3 \text { worm size } \\
\text { classes) } \\
\text {-mortality increases with increasing worm exposure } \\
\text { time and increasing worm size }\end{array}$ \\
\hline 10565 & $\begin{array}{l}\text { Moschino et al. } \\
\text { (2016) }\end{array}$ & Italy & $\begin{array}{c}\text { Mytilus } \\
\text { galloprovincialis }\end{array}$ & Observation & Moderate & Pollutants & $\begin{array}{l}\text {-Metals: } \mathrm{As}, \mathrm{Cd}, \mathrm{Cr}, \mathrm{Cu}, \mathrm{Hg}, \mathrm{Ni}, \mathrm{V}, \\
\mathrm{Pb}, \mathrm{Zn}, \mathrm{Al}, \mathrm{Fe} \\
\text {-PAHs } \\
\text {-Phthalates } \\
\text {-Alkylphenols } \\
\text {-PCBs }\end{array}$ & No & $\begin{array}{l}\text {-mortality at exposed site > mortality at control site } \\
\text {-association of mortality and Aluminium, Iron, Lead, } \\
\text { Total metals and total PAHs }\end{array}$ \\
\hline 10632 & $\begin{array}{l}\text { Zardi et al. } \\
\text { (2016) }\end{array}$ & South Africa & $\begin{array}{c}\text { Mytilus } \\
\text { galloprovincialis }\end{array}$ & Observation & High & Pathogens & -External parasitism (endoliths) & No & $\begin{array}{l}\text {-in periods of high heat (temperature not specified): } \\
\text { mortality among non-infested mussels } 49 \% \text { higher } \\
\text { than among infested mussels }\end{array}$ \\
\hline 10727 & $\begin{array}{l}\text { Cottrell et al. } \\
(2016)\end{array}$ & Scotland & Mytilus edulis & Laboratory & High & $\begin{array}{l}\text {-Seawater characteristics } \\
\text {-Site characteristics }\end{array}$ & $\begin{array}{l}\text {-Sediment size } \\
\text {-Seawater temperature } \\
\text {-Burial sediment duration } \\
\text {-Suspended organic matter } \\
\text { concentration }\end{array}$ & Yes & $\begin{array}{l}\text {-mortality increases with fine sediment } \\
\text {-mortality increases with suspended organic matter } \\
\text { concentration increases } \\
\text {-mortality increases with seawater temperature } \\
\text { increase } \\
\text {-mortality increases with burial duration increases } \\
\text {-significant interaction between sediment size } \\
\text { *suspended organic matter (any concentration) }^{\text {s }}\end{array}$ \\
\hline 10825 & Sun et al. (2016) & China & Mytilus edulis & Laboratory & Moderate & Seawater characteristics & -Seawater $\mathrm{pH}$ & No & $\begin{array}{l}\text {-mortality increases with decreasing } \mathrm{pH}: \\
\mathrm{pH}=8.1 \Leftrightarrow 0 \% \text { mortality } \\
\mathrm{pH}=6.5 \Leftrightarrow 6.7 \% \mathrm{HCl} \text { mortality and } 23.3 \% \mathrm{CO}_{2} \\
\text { mortality }\end{array}$ \\
\hline bi24 & $\begin{array}{l}\text { Tremblay et al. } \\
\text { (1998) }\end{array}$ & Canada & Mytilus edulis & Observation & Moderate & $\begin{array}{l}\text {-Animal characteristics } \\
\text {-Husbandry/fishery practices }\end{array}$ & $\begin{array}{l}\text {-Mussel size }(<30 \mathrm{~mm} \text { vs. }>30 \mathrm{~mm}) \\
\text {-Degree of multiple-locus } \\
\text { heterozygosity } \\
\text {-Energy requirements for } \\
\text { metabolism maintenance } \\
\text {-Suspended cages vs. suspended } \\
\text { socks }\end{array}$ & No & $\begin{array}{l}\text {-absence of mussel size effect } \\
\text {-higher degree of heterozygosity in "resistant" } \\
\text { stocks } \\
\text {-higher energy maintenance needs in stocks with } \\
\text { high mortality } \\
\text {-absence of effect of suspended cages vs. } \\
\text { suspended socks }\end{array}$ \\
\hline 10057_1 & $\begin{array}{l}\text { Hutchison et al. } \\
\text { (2016) }\end{array}$ & $\begin{array}{l}\text { United } \\
\text { Kingdom }\end{array}$ & Mytilus edulis & Laboratory & Moderate & Site characteristics & $\begin{array}{l}\text {-Burial depth } \\
\text {-Burial duration } \\
\text {-Sediment size }\end{array}$ & Yes & $\begin{array}{l}\text {-mortality increases with increasing burial duration } \\
\text {-mortality increases with fine sediment } \\
\text {-no effect of burial depth } \\
\text {-not significant interaction between burial duration }\end{array}$ \\
\hline
\end{tabular}




\begin{tabular}{|c|c|c|c|c|c|c|c|c|c|}
\hline & & & & & & & & & * burial depth \\
\hline $10057 \_2$ & $\begin{array}{l}\text { Hutchison et al. } \\
\text { (2016) }\end{array}$ & $\begin{array}{l}\text { United } \\
\text { Kingdom }\end{array}$ & Mytilus edulis & Laboratory & Moderate & $\begin{array}{l}\text {-Seawater characteristics } \\
\text {-Site characteristics }\end{array}$ & $\begin{array}{l}\text {-Burial depth } \\
\text {-Burial duration } \\
\text {-Seawater temperature }\end{array}$ & Yes & $\begin{array}{l}\text {-mortality increases with increasing burial duration } \\
\text {-mortality increases with seawater temperature } \\
\text { increases } \\
\text {-mortality increases with depth of burial increases } \\
\text {-not significant interaction between burial } \\
\text { duration*seawater temperature }\end{array}$ \\
\hline 10112_a & $\begin{array}{l}\text { Benabdelmouna } \\
\text { \& Ledu (2016) }\end{array}$ & France & Mytilus edulis & Observation & Moderate & Animal characteristics & $\begin{array}{l}\text {-Frequency of individuals having } \\
\text { more than } 10 \% \text { of cytogenetic } \\
\text { abnormalities in haemocytes in the } \\
\text { mussel population }\end{array}$ & No & correlation with mortality $=0,945$ \\
\hline 10112 _b & $\begin{array}{l}\text { Benabdelmouna } \\
\text { \& Ledu (2016) }\end{array}$ & France & $\begin{array}{c}\text { Mytilus } \\
\text { galloprovincialis }\end{array}$ & Observation & Moderate & Animal characteristics & $\begin{array}{l}\text {-Frequency of individuals having } \\
\text { more than } 10 \% \text { of cytogenetic } \\
\text { abnormalities in haemocytes in the } \\
\text { mussel population }\end{array}$ & No & correlation with mortality $=0,945$ \\
\hline 10292_1 & $\begin{array}{l}\text { Travers et al. } \\
\text { (2016) }\end{array}$ & France & Mytilus edulis & Observation & Moderate & $\begin{array}{l}\text {-Seawater characteristics } \\
\text {-Climate characteristics }\end{array}$ & $\begin{array}{l}\text {-Air temperature } \\
\text {-Pluviometry } \\
\text {-Phytoplankton diversity } \\
\text { (environmental DNA) }\end{array}$ & No & $\begin{array}{l}\text {-absence of association between mortality and } \\
\text { pluviometry } \\
\text {-absence of association between mortality and air } \\
\text { temperature } \\
\text {-association between mortality and low } \\
\text { phytoplankton diversity index } \\
\text {-higher relative abundances of phylum communities } \\
\text { Ciliophora, class Euglenoidea }\end{array}$ \\
\hline $10292 \_4$ & $\begin{array}{l}\text { Pépin et al. } \\
\text { (2017) }\end{array}$ & France & Mytilus edulis & Observation & Moderate & Animal characteristics & -Spawning period & No & $\begin{array}{l}\text { - appearance of mortalities associated with an } \\
\text { active gametogenesis phase (stages } 3 \mathrm{~A} \text { and } 3 \mathrm{~B} \text { ) } \\
\text {-cessation of mortalities in July and end of egg } \\
\text { laying (stages } 0 \text { and } 1 \text { observed in September) }\end{array}$ \\
\hline $10292 \_5$ & $\begin{array}{l}\text { Pépin et al. } \\
\text { (2017) }\end{array}$ & France & Mytilus edulis & Observation & High & Animal characteristics & $\begin{array}{l}\text {-Unselected vs. selected } \\
\text { intraspecific genotype (progeny of } \\
\text { mussels that survived a mortality } \\
\text { episode) }\end{array}$ & No & $\begin{array}{l}\text {-effect of the selected intraspecific genotype: } \\
78 \% \text { mortality in unselected genotype vs. } 46 \% \\
\text { mortality in selected genotype }\end{array}$ \\
\hline $10292 \_7$ & $\begin{array}{l}\text { Pépin et al. } \\
\text { (2017) }\end{array}$ & France & Mytilus edulis & Laboratory & Moderate & $\begin{array}{l}\text {-Pathogens } \\
\text {-Animal characteristics }\end{array}$ & $\begin{array}{l}\text {-Not identified infectious agent } \\
\text {-Selected (i.e. which parents } \\
\text { survived from a previous mortality } \\
\text { event) vs. non-selected intraspecific } \\
\text { genotype }\end{array}$ & No & $\begin{array}{l}\text {-horizontal transmission of something leading to } \\
\text { mortality: compatible with an infectious hypothesis } \\
\text {-final cumulative mortality: } 77 \% \text { in non-selected } \\
\text { mussels vs. } 63 \% \text { in selected mussels }\end{array}$ \\
\hline $10292 \_8$ & $\begin{array}{l}\text { Pépin et al. } \\
\text { (2017) }\end{array}$ & France & Mytilus edulis & Observation & High & Animal characteristics & $\begin{array}{l}\text {-Selected (i.e. which parents } \\
\text { survived from a previous mortality } \\
\text { event) vs. non-selected intraspecific } \\
\text { genotype } \\
\text {-Frequency of individuals having } \\
\text { more than } 10 \% \text { of cytogenetic } \\
\text { abnormalities in haemocytes in the } \\
\text { mussel population }\end{array}$ & No & $\begin{array}{l}\text {-selected intraspecific genotype: survival gain of } \\
47 \% \text { on average vs. unselected genotype } \\
\text {-no significant association between mortality and } \\
\text { percentage of cytogenetic abnormalities in } \\
\text { haemocytes }\end{array}$ \\
\hline 10292_10 & $\begin{array}{l}\text { Pépin et al. } \\
\text { (2017) }\end{array}$ & France & Mytilus edulis & Observation & Moderate & Site characteristics & -Site effect & No & $\begin{array}{l}\text {-variations in mortality rates between the sites } \\
\text { monitored }\end{array}$ \\
\hline 10292_12 & $\begin{array}{l}\text { Pépin et al. } \\
\text { (2018) }\end{array}$ & France & Mytilus edulis & Laboratory & Moderate & Animal characteristics & $\begin{array}{l}\text {-Frequency of individuals having } \\
\text { more than } 10 \% \text { of cytogenetic } \\
\text { abnormalities in haemocytes in the } \\
\text { mussel population } \\
\text {-Neoplastic process in the } \\
\text { haemocytes }\end{array}$ & No & $\begin{array}{l}\text {-mussel batches with the highest percentage of } \\
\text { cytogenetic abnormalities have the highest } \\
\text { mortality levels } \\
\text {-presence of neoplastic cells in the haemocytes of } \\
\text { mussels with a high percentage of cytogenetic } \\
\text { abnormalities }\end{array}$ \\
\hline $1228 \_1$ & $\begin{array}{l}\text { Akaishi et al. } \\
\text { (2007) }\end{array}$ & Canada & Mytilus edulis & Laboratory & High & Pollutants & -Untreated wastewater & No & $\begin{array}{l}\text { mortality increases from untreated wastewater } \\
\text { concentration }>50 \% \text {. }\end{array}$ \\
\hline
\end{tabular}




\begin{tabular}{|c|c|c|c|c|c|c|c|c|c|}
\hline 2012_1 & $\begin{array}{l}\text { Hamer et al. } \\
(2008)\end{array}$ & Croatia & $\begin{array}{c}\text { Mytilus } \\
\text { galloprovincialis }\end{array}$ & Laboratory & Moderate & Seawater characteristics & $\begin{array}{l}\text {-Seawater salinity } \\
\text {-Seawater temperature }\end{array}$ & No & $\begin{array}{l}\text {-at } 13^{\circ} \mathrm{C}: \text { no effect of salinity acclimatization } \\
\text {-LT50 at } 27^{\circ} \mathrm{C}: \\
\text { TO: } 5.74, \text { IC95\% [5.45-6.02] } \\
37 \mathrm{psu}: 5.32, \text { IC95\% [5.01-5.62] } \\
28 \mathrm{psu}: 4.26, \text { IC95\% [too broad] } \\
11 \mathrm{psu}: 2.76, \text { IC95\% [2.42-3.08] } \\
\Rightarrow 27^{\circ} \mathrm{C}: \text { mortality increases with acclimatization } \\
\text { below } 28 \mathrm{psu}\end{array}$ \\
\hline 2587_1 & Lowen (2008) & Canada & Mytilus edulis & Observation & Moderate & Animal characteristics & $\begin{array}{l}\text {-Mussel species: M. edulis, M. } \\
\text { trossulus and hybrids }\end{array}$ & No & $\begin{array}{l}\text {-No difference in mortality level between } M \text {. edulis } \\
\text { and } M \text {. trossulus } \\
\text {-Hybrid edulis (female edulis) mortality > mortality } \\
\text { of } M \text {. edulis and } M \text {. trossulus } \\
\text {-Hybrid trossulus (female trossulus) mortality not } \\
\text { different from other genotypes }\end{array}$ \\
\hline $2587 \_2$ & Lowen (2008) & Canada & Mytilus edulis & Observation & Moderate & Husbandry/fishery practices & $\begin{array}{l}\text {-Stocking density } \\
\text {-Mixed mussel species }\end{array}$ & No & $\begin{array}{l}\text {-no stocking density effect on mortality level, } \\
\text { except mortality } M \text {. edulis < mortality M. trossulus if } \\
\text { density= } 30 \text { mussels/cages with mixed species } \\
\text { condition }\end{array}$ \\
\hline $2886 \_1$ & Schneider (2008) & $\begin{array}{l}\text { United } \\
\text { States of } \\
\text { America }\end{array}$ & $\begin{array}{c}\text { Mytilus } \\
\text { galloprovincialis }\end{array}$ & Laboratory & Moderate & $\begin{array}{l}\text {-Animal characteristics } \\
\text {-Climate characteristics }\end{array}$ & $\begin{array}{l}\text {-Mussel species } \\
\text {-Air vs. seawater thermal range }\end{array}$ & No & $\begin{array}{l}\text {-if seawater temperature }=18^{\circ} \mathrm{C}: \text { mortality } M . \\
\text { galloprovincialis }>\text { mortality } M \text {. trossulus } \\
\text {-If seawater temperature }=18^{\circ} \mathrm{C} / \text { air temperature } \\
\text { increases from } 20 \text { to } 30^{\circ} \mathrm{C}: \text { absence of effect of } \\
\text { aerial body temperature on mussel mortality, } \\
\text { regardless of mussel species }\end{array}$ \\
\hline $2886 \_2$ & Schneider (2008) & $\begin{array}{l}\text { United } \\
\text { States of } \\
\text { America }\end{array}$ & $\begin{array}{c}\text { Mytilus } \\
\text { galloprovincialis }\end{array}$ & Laboratory & Moderate & Climate characteristics & $\begin{array}{l}\text {-Mussel species } \\
\text {-Air vs. seawater thermal range }\end{array}$ & No & $\begin{array}{l}\text {-if water temperature }=12^{\circ} \mathrm{C}: \text { mortality } M . \\
\text { galloprovincialis }>\text { mortality } M \text {. trossulus } \\
\text {-if water temperature }=12^{\circ} \mathrm{C} / \text { air temperature } \\
\text { increases from } 20 \text { to } 30^{\circ} \mathrm{C}: \text { mortality } \mathrm{M} \text {. } \\
\text { galloprovincialis decreases at air temperature = } \\
30^{\circ} \mathrm{C}\end{array}$ \\
\hline 3024_1 & $\begin{array}{l}\text { Jones et al. } \\
\text { (2009) }\end{array}$ & $\begin{array}{l}\text { United } \\
\text { States of } \\
\text { America }\end{array}$ & Mytilus edulis & Laboratory & Moderate & $\begin{array}{l}\text {-Seawater characteristics } \\
\text {-Climate characteristics }\end{array}$ & $\begin{array}{l}\text {-Seawater temperature } \\
\text {-Number of exposures to elevated } \\
\text { seawater temperature } \\
\text {-Number of exposures to elevated } \\
\text { air temperature }\end{array}$ & No & $\begin{array}{l}\text {-mortality increases from } 30^{\circ} \mathrm{C} \text { (air or water) } \\
\text {-mortality increases (up to } 100 \% \text { ) with increasing } \\
\text { number of exposures (air or seawater)= multiple } \\
\text { exposure decreases thermal tolerance }\end{array}$ \\
\hline 3267_1 & Vickerson (2009) & Canada & Mytilus edulis & Observation & Moderate & Husbandry/fishery practices & $\begin{array}{l}\text {-Temperature during } 24 \mathrm{H} \text { transport } \\
\text { (with / without ice) } \\
\text {-Antifouling treatment }(30 \mathrm{~s}) \text { before } \\
\text { or after transport ( } 300 \mathrm{ppt} \text { brine / } \\
\text { hydrated lime / vinegar) } \\
\text {-Rinsing of the mussels after the } \\
\text { antifouling treatment }\end{array}$ & No & $\begin{array}{l}\text { Data for } 24 \mathrm{H} \text { transport (only available): } \\
\text {-no difference in mortality between brine } \\
\text { treatments } \\
\text {-mortality between hydrated lime treatments } \\
\text { without rinsing > mortality other hydrated lime } \\
\text { treatments } \\
\text {-mortality vinegar treatment without rinsing before } \\
\text { transport and not stored in ice }(35.4 \%)>\text { mortality } \\
\text { vinegar treatment without rinsing before transport } \\
\text { and stored in ice during transport }(33.7 \%)>>\text { other } \\
\text { vinegar treatment }(<10 \%) \\
\text {-the } 3 \text { antifouling treatments : correlation between } \\
\% \text { mortality and biomass }(r=0.377 / 0.377 / 0.804)\end{array}$ \\
\hline $365 \_2$ & $\begin{array}{l}\text { Altieri \& Witman } \\
\text { (2006) }\end{array}$ & $\begin{array}{l}\text { United } \\
\text { States of } \\
\text { America }\end{array}$ & Mytilus edulis & Observation & Moderate & $\begin{array}{l}\text {-Animal characteristics } \\
\text {-Seawater characteristics }\end{array}$ & $\begin{array}{l}\text {-Hypoxia } \\
\text {-Mussel size } \\
\text {-Mussel growth rate }\end{array}$ & Yes & $\begin{array}{l}\text { under hypoxic conditions: } \\
\text {-mortality increases with increasing mussel size } \\
\text {-correlation between \% mortality and growth rate: } \\
\mathrm{R}^{2}=0.49\end{array}$ \\
\hline
\end{tabular}




\begin{tabular}{|c|c|c|c|c|c|c|c|c|c|}
\hline 365_3 & $\begin{array}{l}\text { Altieri \& Witman } \\
\text { (2006) }\end{array}$ & $\begin{array}{l}\text { United } \\
\text { States of } \\
\text { America }\end{array}$ & Mytilus edulis & Observation & High & -Site characteristics & -Starfish predation & No & $\begin{array}{l}\text { under hypoxic conditions: } \\
\text { no effect of cages (against predation) on mussel } \\
\text { survival during hypoxia, i.e. predation does not play } \\
\text { a particular role in hypoxia concurrences }\end{array}$ \\
\hline 3834_a & O'Connor (2010) & Ireland & Mytilus edulis & Observation & High & $\begin{array}{l}\text {-Pathogens } \\
\text {-Animal characteristics } \\
\text {-Site characteristics }\end{array}$ & $\begin{array}{l}\text {-Presence of perennial epibiont } \\
\text { algae Fucus serratus (exposed sites) } \\
\text { vs. mixture of } F \text {. serratus * F. } \\
\text { spiralus *Ascophyllum nodosum } \\
\text { (sheltered sites) } \\
\text {-Initial mussel size } \\
\text {-Exposed site vs. sheltered wave } \\
\text { site }\end{array}$ & Yes & $\begin{array}{l}\text {-mortality on sheltered sites < wave-exposed sites } \\
\text {-wave sheltered site: mussels with epibionts have a } \\
50 \% \text { higher risk of dying compared to mussels } \\
\text { without epibionts } \\
\text {-no effect of initial mussel size on epibiont-related } \\
\text { mortality }\end{array}$ \\
\hline 3834_b & O'Connor (2010) & Ireland & $\begin{array}{c}\text { Mytilus } \\
\text { galloprovincialis }\end{array}$ & Observation & High & $\begin{array}{l}\text {-Pathogens } \\
\text {-Animal characteristics } \\
\text {-Site characteristics }\end{array}$ & $\begin{array}{l}\text {-Presence of perennial epibiont } \\
\text { algae Fucus serratus (exposed sites) } \\
\text { vs. mixture of } F \text {. serratus }{ }^{*} F \text {. } \\
\text { spiralus *Ascophyllum nodosum } \\
\text { (sheltered sites) } \\
\text {-Initial mussel size } \\
\text {-Exposed site vs. sheltered wave } \\
\text { site }\end{array}$ & Yes & $\begin{array}{l}\text {-mortality on sheltered sites < wave-exposed sites } \\
\text {-wave sheltered site: mussels with epibionts have a } \\
50 \% \text { higher risk of dying compared to mussels } \\
\text { without epibionts } \\
\text {-no effect of initial mussel size on epibiont-related } \\
\text { mortality }\end{array}$ \\
\hline 6023_1 & $\begin{array}{l}\text { Christensen et al. } \\
\text { (2012) }\end{array}$ & Denmark & Mytilus edulis & Laboratory & Moderate & -Site characteristics & $\begin{array}{l}\text {-Predation by crab } \\
\text {-Origin of mussels: bottom bed vs. } \\
\text { farmed suspended }\end{array}$ & No & $\begin{array}{l}\text {-association between mussel mortality and crab } \\
\text { predation, whatever the origin of the mussel spat }\end{array}$ \\
\hline $6023 \_2$ & $\begin{array}{l}\text { Christensen et al. } \\
\text { (2012) }\end{array}$ & Denmark & Mytilus edulis & Observation & High & $\begin{array}{l}\text {-Site characteristics } \\
\text {-Husbandry/fishery practices }\end{array}$ & $\begin{array}{l}\text {-Predation by crab } \\
\text {-Origin of mussels: bottom bed vs. } \\
\text { farmed suspended }\end{array}$ & No & $\begin{array}{l}\text {-predation-related mortality in farmed suspended } \\
\text { mussels }<\text { bottom bed mussels }\end{array}$ \\
\hline 7869_2 & $\begin{array}{l}\text { Romero et al. } \\
\text { (2014) }\end{array}$ & Spain & $\begin{array}{c}\text { Mytilus } \\
\text { galloprovincialis }\end{array}$ & Laboratory & Moderate & $\begin{array}{l}\text {-Pathogens } \\
\text {-Seawater characteristics }\end{array}$ & $\begin{array}{l}\text {-Bacteria Vibrio aestuarianus } \\
\text {-Bacteria Vibrio splendidus clade } \\
\text {-Emersion from water during } 8 \mathrm{~h} \text { vs. } \\
\text { permanent immersion to } \\
\text { reproduce hypoxic stress }\end{array}$ & Yes & $\begin{array}{l}-15^{\circ} \mathrm{C}: \text { mortality }<5 \% \text {, no effect of emersion } \\
-25^{\circ} \mathrm{C} \text { : increased mortality if emersion and seawater } \\
\text { contaminated with Vibrio splendidus clade or Vibrio } \\
\text { aestuarianus }\end{array}$ \\
\hline 8146_1 & $\begin{array}{l}\text { Bressan et } \\
\text { al.(2014) }\end{array}$ & Italy & $\begin{array}{c}\text { Mytilus } \\
\text { galloprovincialis }\end{array}$ & Laboratory & Moderate & Seawater characteristics & $-\mathrm{pH}$ of the seawater & No & $\begin{array}{l}\text {-up to the } 5 \text { th month: } 5.6 \% \text { mortality in controls } \\
\text { and } 5.5 \% \text { mortality in the treated group (variable } \\
\text { pH) } \\
\text {-mortality in the treated group increases at the 6th } \\
\text { month to } 11 \% \text {. } \\
\Rightarrow>\text { mortality increases if prolonged exposure (6 } \\
\text { months) to a low and constant pH (7.4) }\end{array}$ \\
\hline $8146 \_2$ & $\begin{array}{l}\text { Bressan et } \\
\text { al.(2014) }\end{array}$ & Italy & $\begin{array}{c}\text { Mytilus } \\
\text { galloprovincialis }\end{array}$ & Laboratory & Moderate & Seawater characteristics & $-\mathrm{pH}$ of the seawater & No & $\begin{array}{l}-7.25 \% \text { mortality in the control group and } 7.00 \% \\
\text { mortality in the treated group } \\
=>\text { no effect of exposure to a low and constant pH } \\
\text { (7.4) for } 3 \text { months on mortality }\end{array}$ \\
\hline $8841 \_1$ & $\begin{array}{l}\text { Brousscau et al. } \\
\text { (2014) }\end{array}$ & $\begin{array}{l}\text { United } \\
\text { States of } \\
\text { America }\end{array}$ & Mytilus edulis & Observation & Moderate & Site characteristics & $\begin{array}{l}\text {-Predation by the Japanese crab } \\
\text { Hemigrapsus sanguineus }\end{array}$ & No & $\begin{array}{l}\text {-presence of Hemigrapsus sanguineus crab is } \\
\text { associated with an increase in mortality (predation) } \\
\text { of about } 25 \% \text {. }\end{array}$ \\
\hline 8841_2 & $\begin{array}{l}\text { Brousscau et al. } \\
\text { (2014) }\end{array}$ & $\begin{array}{l}\text { United } \\
\text { States of } \\
\text { America }\end{array}$ & Mytilus edulis & Observation & Moderate & Site characteristics & $\begin{array}{l}\text {-Predation by Japanese crab } \\
\text { Hemigrapsus sanguineus }\end{array}$ & No & $\begin{array}{l}\text {-presence of Hemigrapsus sanguineus crab is } \\
\text { associated with an increase in mortality (predation) }\end{array}$ \\
\hline
\end{tabular}




\begin{tabular}{|c|c|c|c|c|c|c|c|c|c|}
\hline 9283_1 & $\begin{array}{l}\text { Carella et al. } \\
(2105)\end{array}$ & Italy & $\begin{array}{c}\text { Mytilus } \\
\text { galloprovincialis }\end{array}$ & Laboratory & Moderate & Pathogens & $\begin{array}{l}\text {-Toxic dinoflagellate algae } \\
\text { Ostreopsis cf ovata }\end{array}$ & No & $\begin{array}{l}\text {-concentration } 300 \text { cells } / \mathrm{ml}: 7 \% \text { mortality (1 } \\
\text { mold/15) after } 24 \mathrm{H} \text { and } 10 \% \text { after } 48 \mathrm{H} \\
\text {-concentration } 500 \text { cells } / \mathrm{ml}: 15 \% \text { mortality (2 } \\
\text { mold/15) after } 24 \mathrm{H} \text { and } 40 \% \text { after } 48 \mathrm{H} \\
\text {-concentration } 1000 \text { cells/ml: } 93 \% \text { mortality ( } 14 \\
\text { mold/15) after } 24 \mathrm{H} \\
\text { => mussel mortality is proportional to the } \\
\text { concentration of toxic algae }\end{array}$ \\
\hline 996_1 & $\begin{array}{l}\text { Zardi et al. } \\
\text { (2006) }\end{array}$ & South Africa & $\begin{array}{c}\text { Mytilus } \\
\text { galloprovincialis }\end{array}$ & Observation & Moderate & Site characteristics & -Sand burial & No & $\begin{array}{l}\text {-mortality increases with duration of sand burial } \\
\text { increases } \\
\text {-after } 6 \text { days, } 50 \% \text { of the mussels are dead }\end{array}$ \\
\hline $996 \_2$ & $\begin{array}{l}\text { Zardi et al. } \\
\text { (2006) }\end{array}$ & South Africa & $\begin{array}{c}\text { Mytilus } \\
\text { galloprovincialis }\end{array}$ & Laboratory & High & Site characteristics & -Sand burial & No & $\begin{array}{l}\text {-suspended sand: } \mathrm{LT} 50=14 \text { days } \\
\text {-sand burial: } \mathrm{LT50}=6 \text { days }\end{array}$ \\
\hline bi2 & $\begin{array}{l}\text { Eggermont et al. } \\
\text { (2014) }\end{array}$ & Belgium & Mytilus edulis & Laboratory & Moderate & Pathogens & $\begin{array}{l}\text {-Opportunistic heterotrophic } \\
\text { bacteria }\end{array}$ & No & $\begin{array}{l}\text {-treated condition: } 100 \% \text { mortality in } 6 \text { days } \\
\text {-control with antibiotic: } 25 \% \text { mortality } \\
\text {-other controls: } 0 \% \text { mortality }\end{array}$ \\
\hline bi5 & $\begin{array}{l}\text { Myrand \& } \\
\text { Gaudreault } \\
\text { (1995) }\end{array}$ & Canada & Mytilus edulis & Observation & Moderate & $\begin{array}{l}\text {-Animal characteristics } \\
\text {-Site characteristics } \\
\text {-Husbandry/fishery practices }\end{array}$ & $\begin{array}{l}\text {-Selected (survivors from a previous } \\
\text { mortality event) vs. non-selected } \\
\text { intraspecific genotype } \\
\text {-Site } \\
\text {-Geographic origin of spat }\end{array}$ & Yes & $\begin{array}{l}\text {-no effect of intraspecific genotype } \\
\text {-no difference in mortality between sites } \\
\text {-intrasite: effect of spat origin } \\
\text {-intersite: same effect of spat origin } \\
\text {-non significant interaction site*spat origin }\end{array}$ \\
\hline bi6 & $\begin{array}{l}\text { Karayücel \& } \\
\text { Karayücel (2000) }\end{array}$ & Scotland & Mytilus edulis & Observation & Moderate & Husbandry/fishery practices & $\begin{array}{l}\text {-Depth of the farming structures: } 2 \\
\mathrm{~m} \text { vs. } 6 \mathrm{~m} \\
\text {-Position inside the farming } \\
\text { structure (inflow vs. outflow) }\end{array}$ & No & $\begin{array}{l}\text {-no effect of the depth of the farming structure } \\
\text {-no effect of the position inside the farming } \\
\text { structure, related to marine currents }\end{array}$ \\
\hline bi7 & Tsuchiya (1983) & Japan & Mytilus edulis & Observation & High & $\begin{array}{l}\text {-Animal characteristics } \\
\text {-Site characteristics } \\
\text {-Climate characteristics }\end{array}$ & $\begin{array}{l}\text {-Mussel size } \\
\text {-Height on the shore } \\
\text {-Elevated air temperature (heat } \\
\text { wave) }\end{array}$ & No & $\begin{array}{l}\text {-no link between mussel size and mortality } \\
\text {-higher mortality if high position on the shore } \\
\text {-link between wave heat and mortality }\end{array}$ \\
\hline bi8 & $\begin{array}{l}\text { Stirling \& } \\
\text { Okumus (1994) }\end{array}$ & Scotland & Mytilus edulis & Observation & Moderate & $\begin{array}{l}\text {-Site characteristics } \\
\text {-Husbandry/fishery practices }\end{array}$ & $\begin{array}{l}\text {-Site } \\
\text {-Geographic origin of spat: local vs. } \\
\text { translocated }\end{array}$ & No & $\begin{array}{l}\text {-no site effect } \\
\text {-no effect of spat origin }\end{array}$ \\
\hline bi10 & $\begin{array}{l}\text { Petraitis (1998) } \\
\end{array}$ & $\begin{array}{l}\text { United } \\
\text { States of } \\
\text { America }\end{array}$ & Mytilus edulis & Observation & Moderate & Site characteristics & $\begin{array}{l}\text {-Position on the shore: high vs. low } \\
\text {-Predation by the snail Nucella } \\
\text { lapillus }\end{array}$ & No & $\begin{array}{l}\text { - } 64 \% \text { of deaths due to predation by the snail } \\
\text {-no association between predator abundance and } \\
\text { mortality } \\
\text {-higher mortality on the higher shore }\end{array}$ \\
\hline bi11 & $\begin{array}{l}\text { Myrand et al. } \\
(2000)\end{array}$ & Canada & Mytilus edulis & Observation & High & $\begin{array}{l}\text {-Animal characteristics } \\
\text {-Husbandry/fishery practices } \\
\text { characteristics } \\
\text {-Climate characteristics }\end{array}$ & $\begin{array}{l}\text {-Physiological state of mussels: } \\
\text { gametogenesis, energy reserves } \\
\text {-Suspended cages at } 16 \mathrm{~m} \text { (open } \\
\text { water) vs. } 6 \mathrm{~m} \text { depth (lagoon) } \\
\text {-Season }\end{array}$ & No & $\begin{array}{l}\text {-mortality in the lagoon ( } 6 \mathrm{~m} \text { depth) higher than } \\
\text { mortality in the open sea ( } 16 \mathrm{~m} \text { depth) } \\
\text {-foreshore: link between the beginning of mortality } \\
\text { and the end of the second spawning + low energy } \\
\text { reserves } \\
\text {-mortality higher in summer (June-September) }\end{array}$ \\
\hline bi12_1 & $\begin{array}{l}\text { Lauzon-Gay et al. } \\
\text { (2005) }\end{array}$ & Canada & Mytilus edulis & Observation & High & $\begin{array}{l}\text {-Animal characteristics } \\
\text {-Site characteristics } \\
\text {-Husbandry/fishery practices }\end{array}$ & $\begin{array}{l}\text {-Seed size } \\
\text {-Site } \\
\text {-Initial density in socks }\end{array}$ & No & $\begin{array}{l}\text {-no site effect } \\
\text {-Month 10: mortality of small mussels higher than } \\
\text { that of medium and large mussels } \\
\text {-Month 18: mortality of high initial densities higher } \\
\text { than that of low initial densities, regardless of size }\end{array}$ \\
\hline bi12_2 & $\begin{array}{l}\text { Lauzon-Gay et al. } \\
\text { (2005) }\end{array}$ & Canada & Mytilus edulis & Observation & High & $\begin{array}{l}\text {-Animal characteristics } \\
\text {-Husbandry/fishery practices }\end{array}$ & $\begin{array}{l}\text {-Seed size } \\
\text {-Initial density in socks }\end{array}$ & Yes & $\begin{array}{l}\text {-no initial density effect } \\
\text {-mortality of small mussels higher than mortality of } \\
\text { medium and large mussels } \\
\text {-mortality of high initial densities higher than that } \\
\text { of low initial densities, regardless of size }\end{array}$ \\
\hline
\end{tabular}




\begin{tabular}{|c|c|c|c|c|c|c|c|c|c|}
\hline bi15 & $\begin{array}{l}\text { Mallet et al. } \\
\text { (1987) }\end{array}$ & Canada & Mytilus edulis & Observation & Moderate & $\begin{array}{l}\text {-Site characteristics } \\
\text {-Husbandry/fishery practices } \\
\text {-Climate characteristics }\end{array}$ & $\begin{array}{l}\text {-Site } \\
\text {-Origin of spat: local vs. } \\
\text { transplanted } \\
\text {-Geographic origin of spat } \\
\text {-Season }\end{array}$ & Yes & $\begin{array}{l}\text {-no site effect } \\
\text {-spat geographical origin effect } \\
\text {-no native vs. transplanted origin effect } \\
\text {-no single significant seasonal effect } \\
\text {-origin*season significant interaction } \\
\text {-origin*site significant interaction }\end{array}$ \\
\hline bi16 & $\begin{array}{l}\text { Incze et al. } \\
(1980)\end{array}$ & $\begin{array}{l}\text { United } \\
\text { States of } \\
\text { America }\end{array}$ & Mytilus edulis & Observation & Moderate & Seawater characteristics & $\begin{array}{l}\text {-Surface seawater temperature } \\
\text {-Size, abundance and nature of } \\
\text { particles in seawater: total } \\
\text { chlorophyll, nanoplankton }(<20 \mu \mathrm{m})\end{array}$ & No & $\begin{array}{l}\text {-increase in seawater temperature }\left(20^{\circ} \mathrm{C} \text { threshold }\right) \\
+ \text { sudden decrease in the quantity of particles } \\
\text { before a mortality episode }\end{array}$ \\
\hline bi18_a & $\begin{array}{l}\text { Fuentes et al. } \\
(2002)\end{array}$ & Spain & Mytilus edulis & Observation & High & Animal characteristics & -Interspecific genotype & No & $\begin{array}{l}\text {-genotype effect: } M \text {. edulis hybrid mortality higher } \\
\text { than M. galloprovincialis mortality }\end{array}$ \\
\hline bi18_b & $\begin{array}{l}\text { Fuentes et al. } \\
\text { (2002) }\end{array}$ & Spain & $\begin{array}{c}\text { Mytilus } \\
\text { galloprovincialis }\end{array}$ & Observation & High & Animal characteristics & -Interspecific genotype & No & $\begin{array}{l}\text {-genotype effect: } M \text {. edulis hybrid mortality higher } \\
\text { than M. galloprovincialis mortality }\end{array}$ \\
\hline bi19 & $\begin{array}{l}\text { Gardner \& } \\
\text { Thompson } \\
\text { (2001) }\end{array}$ & Canada & Mytilus edulis & Laboratory & Moderate & Animal characteristics & -Species M. edulis vs. M. trossulus & No & $\begin{array}{l}\text {-in coastal regime: low mortality, difference could } \\
\text { not be tested (too small sample) } \\
\text {-in estuarine regime: } M \text {. trossulus mortality higher } \\
\text { than that of } M \text {. edulis }\end{array}$ \\
\hline bi21 & $\begin{array}{l}\text { Mallet et al. } \\
\text { (1990) }\end{array}$ & Canada & Mytilus edulis & Observation & Moderate & $\begin{array}{l}\text {-Animal characteristics } \\
\text {-Site characteristics } \\
\text {-Husbandry/fishery practices }\end{array}$ & $\begin{array}{l}\text {-Age: juveniles vs. adults } \\
\text {-Site (not detailed) } \\
\text {-Geographic origin of spat }\end{array}$ & Yes & $\begin{array}{l}\text {-age effect: juvenile mortality higher than adult } \\
\text { mortality } \\
\text {-no site effect } \\
\text {-spat origin effect }\end{array}$ \\
\hline bi22 & $\begin{array}{l}\text { Fuentes et al. } \\
\text { (1992) }\end{array}$ & Spain & $\begin{array}{c}\text { Mytilus } \\
\text { galloprovincialis }\end{array}$ & Observation & Moderate & $\begin{array}{l}\text {-Site characteristics } \\
\text {-Husbandry/fishery practices }\end{array}$ & $\begin{array}{l}\text {-Site } \\
\text {-Geographic origin of spat } \\
\text {-Position inside the farming } \\
\text { structure (fore vs. aft part of the } \\
\text { raft) }\end{array}$ & Yes & $\begin{array}{l}\text {-no site effect } \\
\text {-effect of spat origin } \\
\text {-no effect of position inside the farming structure }\end{array}$ \\
\hline bi25 & $\begin{array}{l}\text { Fuentes et al. } \\
\text { (1994) }\end{array}$ & Spain & $\begin{array}{c}\text { Mytilus } \\
\text { galloprovincialis }\end{array}$ & Observation & Moderate & $\begin{array}{l}\text {-Site characteristics } \\
\text {-Husbandry/fishery practices }\end{array}$ & $\begin{array}{l}- \text { Site } \\
\text {-Geographic origin of spat } \\
\text {-Position inside the farming } \\
\text { structure (fore vs. aft part of the } \\
\text { raft) }\end{array}$ & No & $\begin{array}{l}\text {-site effect } \\
\text {-effect of the position inside the farming structure: } \\
\text { mortality at the front of the structure lower than } \\
\text { mortality at the back of the structure (relative to } \\
\text { current) } \\
\text { - effect of spat origin: mortality of sites in the north } \\
>\text { mortality of sites in the south }\end{array}$ \\
\hline LG57 & $\begin{array}{l}\text { Glize et al. } \\
\text { (2017) }\end{array}$ & France & Mytilus edulis & Observation & Moderate & $\begin{array}{l}\text {-Site characteristics } \\
\text {-Husbandry/fishery practices }\end{array}$ & $\begin{array}{l}\text {-Site } \\
\text {-Geographic origin of spat } \\
\text {-Geographic origin of spat: local vs. } \\
\text { transplanted from an area not } \\
\text { affected by mortality events }\end{array}$ & No & $\begin{array}{l}\text {-mortality varied between sites } \\
\text {-no difference in mortality levels between the } 2 \\
\text { origins, on } 7 \text { of the } 8 \text { sites } \\
\text {-on } 1 \text { site: } 14.3 \% \text { mortality for local origin vs. } 0.8 \% \\
\text { origin "not affected by mortality" }\end{array}$ \\
\hline LG59 & SMIDAP (2016) & France & Mytilus edulis & Observation & Moderate & -Husbandry/fishery practices & $\begin{array}{l}\text {-Geographic origin of spat: local vs. } \\
\text { transplanted from an area not } \\
\text { affected by mortality events }\end{array}$ & No & $\begin{array}{l}\text { absence of association between spat origin and } \\
\text { mortality }\end{array}$ \\
\hline LG60 & $\begin{array}{l}\text { SMIDAP (2016- } \\
\text { 2017) }\end{array}$ & France & Mytilus edulis & Observation & Moderate & -Husbandry/fishery practices & $\begin{array}{l}\text {-Geographic origin of spat } \\
\text {-Geographic origin of spat: local vs. } \\
\text { transplanted from an area not } \\
\text { affected by mortality events }\end{array}$ & No & $\begin{array}{l}\text {-absence of association between spat origin and } \\
\text { mortality } \\
\text {-mortality of the local mussels }>\text { mortality of the } \\
\text { mussels transplanted from an area not affected by } \\
\text { mortality events }\end{array}$ \\
\hline LG82_a & $\begin{array}{l}\text { Bernard et al. } \\
\text { (2018a) } \\
\text { Bernard et al. } \\
\text { (2018b) }\end{array}$ & France & Mytilus edulis & Observation & Moderate & $\begin{array}{l}\text {-Pathogens } \\
\text {-Animal characteristics } \\
\text {-Seawater characteristics } \\
\text {-Site characteristics } \\
\text {-Husbandry/fishery practices } \\
\text {-Climate characteristics, }\end{array}$ & $\begin{array}{l}\text {-Bacteria, Marteilia refringens } \\
\text {-Mussel species, age, origin, } \\
\text { transmissible neoplasia } \\
\text {-Seawater temperature } \\
\text {-Site } \\
\text {-Geographic origin of spat } \\
\text {-Season }\end{array}$ & No & $\begin{array}{l}\text {-absence of association between Marteilia } \\
\text { refringens and mortality } \\
\text {-absence of association between bacteriological } \\
\text { profile of mussels and mortality } \\
\text {-association between haemocytic tissue infiltration } \\
\text { and mortality } \\
\text {-absence of association between haemocytic } \\
\text { neoplasia and mortality } \\
\text {-association between seawater temperature and }\end{array}$ \\
\hline
\end{tabular}




\begin{tabular}{|c|c|c|c|c|c|c|c|c|c|}
\hline & & & & & & & & & $\begin{array}{l}\text { mortality: thermal threshold between } 19-20^{\circ} \mathrm{C} \\
\text {-site effect } \\
\text {-effect of geographical origin of the animals } \\
\text {-peak mortality in spring }\end{array}$ \\
\hline LG82_b & $\begin{array}{l}\text { Bernard et al. } \\
\text { (2018a) } \\
\text { Bernard et al. } \\
\text { (2018b) }\end{array}$ & France & $\begin{array}{c}\text { Mytilus } \\
\text { galloprovincialis }\end{array}$ & Observation & Moderate & $\begin{array}{l}\text {-Pathogens } \\
\text {-Husbandry/fishery practices } \\
\text {-Climate characteristics, }\end{array}$ & $\begin{array}{l}\text {-Bacteria } \\
\text {-Geographic origin of spat } \\
\text {-Season }\end{array}$ & No & $\begin{array}{l}\text {-absence of association between bacteriological } \\
\text { profile of mussels and mortality } \\
\text {-effect of geographical origin of the animals } \\
\text {-peak mortality in spring }\end{array}$ \\
\hline LG83 & $\begin{array}{l}\text { Glize \& } \\
\text { Gourmelen } \\
\text { (2018) }\end{array}$ & France & Mytilus edulis & Observation & Moderate & $\begin{array}{l}\text {-Site characteristics } \\
\text {-Husbandry/fishery practices }\end{array}$ & $\begin{array}{l}\text {-Site } \\
\text {-Geographic origin of spat: local vs. } \\
\text { transplanted from an area not } \\
\text { affected by mortality events }\end{array}$ & No & $\begin{array}{l}\text {-effect of the site on mortality : mortality of sites in } \\
\text { the North higher than mortality of sites in the South } \\
\text {-absence of association between spat origin and } \\
\text { mortality }\end{array}$ \\
\hline maj1003 & $\begin{array}{l}\text { Clements et al. } \\
\text { (2018) }\end{array}$ & Canada & Mytilus edulis & Laboratory & High & -Seawater characteristics & $\begin{array}{l}\text {-Acidification of seawater } \\
\text {-Increase in seawater temperature }\end{array}$ & Yes & $\begin{array}{l}\text {-no effect of } \mathrm{CO} 2 \text { concentration in seawater on } \\
\text { mortality } \\
\text {-effect of temperature increase on mortality, which } \\
\text { increases with time increases } \\
\text {-with high temperature: observed decrease in } \\
\text { glycogen. The authors make a link (not } \\
\text { demonstrated by this study) between glycogen } \\
\text { reduction and increased mortality } \\
\text {-no effect of the interaction of elevated seawater } \\
\text { temperature*acidification }\end{array}$ \\
\hline maj1351 & $\begin{array}{l}\text { Ajjabi et al. } \\
\text { (2018) }\end{array}$ & Tunisia & $\begin{array}{c}\text { Mytilus } \\
\text { galloprovincialis }\end{array}$ & Laboratory & High & -Husbandry/fishery practices & $\begin{array}{l}\text {-Polyculture with macroalgae } \\
\text { culture Gracilaria verrucosa }\end{array}$ & No & $\begin{array}{l}\text {-controls (monoculture): } 16.25 \% \text { mortality } \\
\text {-polyculture (regardless of algae concentration): no } \\
\text { mortality }\end{array}$ \\
\hline maj1428 & $\begin{array}{l}\text { Gvozdenovic et } \\
\text { al. (2017) }\end{array}$ & Montenegro & $\begin{array}{c}\text { Mytilus } \\
\text { galloprovincialis }\end{array}$ & Observation & Moderate & -Husbandry/fishery practices & $\begin{array}{l}\text {-Polyculture with fish and flat } \\
\text { oysters vs. mussel monoculture }\end{array}$ & No & $\begin{array}{l}\text {-no difference in cumulative mortality between the } \\
3 \text { sites, nor kinetics (data not used in the article, } \\
\text { Table 1) } \\
\text {-no effect of mussel farming near fish farms on } \\
\text { mussel mortality }\end{array}$ \\
\hline maj1757 & $\begin{array}{l}\text { Oliveira et al. } \\
\text { (2017) }\end{array}$ & Portugal & $\begin{array}{c}\text { Mytilus } \\
\text { galloprovincialis }\end{array}$ & Laboratory & High & -Pollutants & -Carbamazepine & No & $\begin{array}{l}\text {-no mortality observed at } 96 \mathrm{H} \text { exposure } \\
\text {-at } 28 \text { days of exposure: } \\
6.0 \text { microg/L: } 12.5 \% \text { mortality } \\
9.0 \text { microg/L : } 6.3 \% \text { mortality }\end{array}$ \\
\hline maj1890 & $\begin{array}{l}\text { Eggermont et al. } \\
\text { (2017) }\end{array}$ & Netherlands & Mytilus edulis & Laboratory & Moderate & -Pathogens & -Cultivable bacteria & No & $\begin{array}{l}-100 \% \text { mortality in } 1 \text { week } \\
- \text { control with rifampin: } 25 \% \text { mortality in } 1 \text { week } \\
-17 \text { isolates during mortality: } 8 \text { belonging to the } \\
\text { Splendidus clade of Vibrios and the others to the } \\
\text { genus Photobacterium }\end{array}$ \\
\hline maj2462 & $\begin{array}{l}\text { Kovacic et al. } \\
\text { (2017) }\end{array}$ & Croatia & $\begin{array}{c}\text { Mytilus } \\
\text { galloprovincialis }\end{array}$ & Observation & Moderate & -Husbandry/fishery practices & $\begin{array}{l}\text {-Geographic origin of spat: local vs. } \\
\text { translocated }\end{array}$ & No & $\begin{array}{l}\text { - varying mortality depending on the origin of the } \\
\text { mussels (from } 13.13 \% \text { to } 37.66 \% \text { ): lower mortality } \\
\text { in translocated mussels }\end{array}$ \\
\hline maj2616 & $\begin{array}{l}\text { Theodorou et al. } \\
\text { (2017)) }\end{array}$ & Greece & $\begin{array}{c}\text { Mytilus } \\
\text { galloprovincialis }\end{array}$ & Observation & Moderate & -Husbandry/fishery practices & $\begin{array}{l}\text {-Stocking density during immersion } \\
\text { before transport for sale }(7.5 \text { / } 10 \text { / } \\
10 / 12.5 / 15.5 \mathrm{~kg} \text { per bag) } \\
\text {-Re-immersion time (11 / } 25 \text { / } 37 \text { / } \\
46 \text { days) }\end{array}$ & No & $\begin{array}{l}\text {-no difference in mortality between the different } \\
\text { storage densities, at each time step (? Little } \\
\text { consistent with Figure } 1 \text { ) } \\
\text {-mortality }<10 \% \text { up to } 11 \text { days of storage for } \\
\text { densities }<12.5 \mathrm{~kg} \text {, with the exception of density } \\
12.5 \mathrm{~kg} \text { : up to } 25 \text { days }\end{array}$ \\
\hline maj2926 & $\begin{array}{l}\text { Moschino et al. } \\
\text { (2017) }\end{array}$ & Italy & $\begin{array}{c}\text { Mytilus } \\
\text { galloprovincialis } \\
\end{array}$ & Observation & Moderate & -Site characteristics & -Site $(N=4)$ & No & Site effect \\
\hline maj989 & Li et al. (2018) & China & $\begin{array}{c}\text { Mytilus } \\
\text { galloprovincialis }\end{array}$ & Laboratory & Moderate & -Pollutants & $-\mathrm{ZnO}$ & No & $\begin{array}{l}\text {-coarse suspension ZnO: LC50 = } 2.62 \mathrm{mg} \mathrm{Zn} / \mathrm{L}[1.00- \\
4.00] \\
\text {-nanoparticles ZnO: } \mathrm{LC} 50=0.78 \mathrm{mg} \mathrm{Zn/L} \mathrm{[0.64-} \\
1.00], 100 \% \text { mortality at } 14 \text { days per } 100 \mathrm{mg} / \mathrm{L} \text { and } \\
21 \text { days per } 10 \mathrm{mg} / \mathrm{L}\end{array}$ \\
\hline
\end{tabular}




\begin{tabular}{|c|c|c|c|c|c|c|c|c|c|}
\hline & & & & & & & & & $\begin{array}{l}-\mathrm{ZnSO} 4: \mathrm{LC} 50=0.25 \mathrm{mg} \mathrm{Zn} / \mathrm{L}[0.10-0.40] \\
100 \% \text { mortality at } 4 \text { days per } 10 \mathrm{mg} / \mathrm{L} \text { and higher } \\
\text { concentrations }\end{array}$ \\
\hline maj2_129a & Lenz et al. (2018) & $\begin{array}{l}\text { Finland, } \\
\text { Germany, } \\
\text { Portugal }\end{array}$ & $\begin{array}{c}\text { Mytilus } \\
\text { galloprovincialis }\end{array}$ & Laboratory & Moderate & -Seawater characteristics & -Number of thermal stresses & No & $\begin{array}{l}\text {-no difference in mortality between group A } \\
\text { exposed twice to stress and group B exposed only } \\
\text { once to stress } \\
\text {-no effect of a first exposure to an elevated } \\
\text { temperature on the mortality level following a } \\
\text { second exposure to the same stress }\end{array}$ \\
\hline maj2_129b & Lenz et al. (2018) & $\begin{array}{l}\text { Finland, } \\
\text { Germany, } \\
\text { Portugal }\end{array}$ & Mytilus edulis & Laboratory & Moderate & -Seawater characteristics & -Number of thermal stresses & No & $\begin{array}{l}\text { mortality after a second exposure to an elevated } \\
\text { temperature is lower than mortality after a first } \\
\text { exposure to the same stress }\end{array}$ \\
\hline maj2_147_1 & $\begin{array}{l}\text { Stevens \& Gobler } \\
(2018)\end{array}$ & $\begin{array}{l}\text { United } \\
\text { States of } \\
\text { America }\end{array}$ & Mytilus edulis & Laboratory & High & -Seawater characteristics & $\begin{array}{l}\text {-Decreased } \mathrm{pH} \\
\text {-Decrease in dissolved oxygen }\end{array}$ & Yes & $\begin{array}{l}\text {-effect of } \mathrm{pH} \text { decrease on mortality: mortality } \\
\text { increases when } \mathrm{pH} \text { decreases } \\
0 \% \text { mortality in the control group } \\
2 \% \text { mortality when } \mathrm{pH} \text { decreased, statistically } \\
\text { significant difference }(\mathrm{P}<0.05) \\
\text {-no effect of oxygen depletion } \\
\text {-no effect of pH decrease* oxygen depletion }\end{array}$ \\
\hline maj2_147_2 & $\begin{array}{l}\text { Stevens \& Gobler } \\
\text { (2018) }\end{array}$ & $\begin{array}{l}\text { United } \\
\text { States of } \\
\text { America }\end{array}$ & Mytilus edulis & Laboratory & High & -Seawater characteristics & $\begin{array}{l}\text {-Elevated seawater temperature } \\
\text {-Decreased pH } \\
\text {-Decrease in dissolved oxygen }\end{array}$ & Yes & $\begin{array}{l}\text {-no } \mathrm{pH} \text { decrease effect } \\
\text {-no oxygen decrease effect } \\
\text {-no elevated water temperature effect } \\
\text {-non significant interaction } \mathrm{pH} \text { decrease* oxygen } \\
\text { decrease } \\
\text {-non significant interaction } \mathrm{pH} \text { decrease*elevated } \\
\text { temperature } \\
\text {-non significant interaction oxygen decrease * } \\
\text { elevated temperature } \\
\text {-non significant interaction } \mathrm{pH} \text { decrease*oxygen } \\
\text { decrease*elevated temperature }\end{array}$ \\
\hline maj2_152_1 & $\begin{array}{l}\text { Bertolini et al. } \\
\text { (2018) }\end{array}$ & Ireland & Mytilus edulis & Laboratory & Moderate & -Site characteristics & $\begin{array}{l}\text {-Predation by the crab Carcinus } \\
\text { maenas } \\
\text {-Habitat complexity }\end{array}$ & Yes & $\begin{array}{l}\text {-effect of habitat complexity on mortality in crab } \\
\text { predation: mortality decreases with habitat } \\
\text { complexity increases, regardless of mussel size } \\
\text {-effect of predator size: total mussel mortality } \\
\text { (small and large) increases with crab size increases }\end{array}$ \\
\hline maj2_152_2_2 & $\begin{array}{l}\text { Bertolini et al. } \\
\text { (2018) }\end{array}$ & Ireland & Mytilus edulis & Laboratory & Moderate & -Site characteristics & $\begin{array}{l}\text {-Predation by the starfish Asterias } \\
\text { rubens } \\
\text {-Habitat complexity }\end{array}$ & Yes & $\begin{array}{l}\text {-absence of effect of habitat complexity on total } \\
\text { mussel mortality in case of starfish predation } \\
\text {-effect of habitat complexity on small mussel } \\
\text { mortality in case of starfish predation : mortality } \\
\text { decreases with habitat complexity increases } \\
\text {-effect of predator size : total mussel mortality } \\
\text { (small and large) increases with starfish size } \\
\text { increases }\end{array}$ \\
\hline maj2_153 & $\begin{array}{l}\text { Peden et al. } \\
\text { (2018) }\end{array}$ & France & Mytilus edulis & Laboratory & Moderate & -Climate characteristics & $\begin{array}{l}\text {-Animals chronically exposed to } \\
\text { pollution (from a polluted site) } \\
\text {-Number of thermal stresses }\end{array}$ & Yes & $\begin{array}{l}\text {-acclimatisation to elevated temperature reduces } \\
\text { mortality associated with a heat wave: } \\
\text { mortality in acclimatised group }=8.3 \% \text { / in non- } \\
\text { acclimatised group }=51.7 \%\end{array}$ \\
\hline maj2_155_1_1_a & $\begin{array}{l}\text { Benabdelmouna } \\
\text { et al. (2018) }\end{array}$ & France & Mytilus edulis & Laboratory & Moderate & -Pathogens & $\begin{array}{l}\text {-Bacteria Vibrio Splendidus clade } \\
\text {-Bacteria Vibrio aestuarianus } \\
\text {-Virus OsHV-1 } \\
\text {-Marteilia refringens and other } \\
\text { notifiable pathogens }\end{array}$ & No & $\begin{array}{l}\text {-in moribund mussels: no detection of notifiable } \\
\text { parasites, OsHV-1, Vibrio aestuarianus but } \\
\text { detection of Vibrio Splendidus clade, except in } \\
\text { August } \\
\text {-horizontal transmission of an infectious agent } \\
\text { between adult mussels, resulting in mortality } \\
\text {-absence of formal evidence of involvement of } \\
\text { Vibrio bacteria of the genus Splendidus }\end{array}$ \\
\hline
\end{tabular}




\begin{tabular}{|c|c|c|c|c|c|c|c|c|c|}
\hline maj2_155_1_b & $\begin{array}{l}\text { Benabdelmouna } \\
\text { et al. (2018) }\end{array}$ & France & $\begin{array}{c}\text { Mytilus } \\
\text { galloprovincialis }\end{array}$ & Laboratory & Moderate & -Pathogens & $\begin{array}{l}\text {-Bacteria Vibrio Splendidus clade } \\
\text {-Bacteria Vibrio aestuarianus } \\
\text {-Virus OsHV-1 } \\
\text {-Marteilia refringens and other } \\
\text { notifiable pathogens }\end{array}$ & No & $\begin{array}{l}\text {-in moribund mussels: no detection of notifiable } \\
\text { parasites, OsHV-1, Vibrio aestuarianus but } \\
\text { detection of Vibrio Splendidus clade, except in } \\
\text { August } \\
\text {-horizontal transmission of an infectious agent } \\
\text { between adult mussels, resulting in mortality } \\
\text {-absence of formal evidence of involvement of } \\
\text { Vibrio bacteria of the genus Splendidus }\end{array}$ \\
\hline maj2_235_1 & $\begin{array}{l}\text { Wang et al. } \\
\text { (2018) }\end{array}$ & China & Mytilus edulis & Laboratory & High & -Seawater characteristics & $\begin{array}{l}\text {-Decreased seawater temperature } \\
\text {-Elevated seawater temperature }\end{array}$ & No & $\begin{array}{l}\text {-high mortality at high }\left(35^{\circ} \mathrm{C}\right) \text { or cold }\left(4^{\circ} \mathrm{C}\right) \\
\text { temperatures } \\
4^{\circ} \mathrm{C}: 28 \% \text { mortality } / 9^{\circ} \mathrm{C}: 20 \% / 15^{\circ} \mathrm{C}: 4 \% / 25^{\circ} \mathrm{C}: \\
5 \% / 30^{\circ} \mathrm{C}: 7 \% / 35^{\circ} \mathrm{C}: 20 \% \text { mortality }\end{array}$ \\
\hline maj2_486 & $\begin{array}{l}\text { Nicastro et al. } \\
\text { (2018) }\end{array}$ & South Africa & $\begin{array}{c}\text { Mytilus } \\
\text { galloprovincialis }\end{array}$ & Observation & High & $\begin{array}{l}\text {-Pathogens } \\
\text {-Husbandry/fishery practices }\end{array}$ & $\begin{array}{l}\text {-Endolithic infestation } \\
\text {-Intensity of trampling during bed } \\
\text { harvesting }\end{array}$ & Yes & $\begin{array}{l}\text { endolithic infestation of mussels increases the } \\
\text { mortality by trampling (i.e. crushing) }\end{array}$ \\
\hline maj2_624 & $\begin{array}{l}\text { Binzer et al. } \\
\text { (2018) }\end{array}$ & Denmark & Mytilus edulis & Laboratory & High & -Pathogens & -Toxic algae Karlodinium armiger & No & $\begin{array}{l}\text {-LC50 at } 24 \mathrm{H}=9.4^{*} 10^{\wedge} 3+/-2.7^{*} 10^{\wedge} 3 \text { cells } / \mathrm{mL} \\
\text {-LC50 at } 48 \mathrm{H}=6.1^{*} 10^{\wedge} 3+/-0.3^{*} 10^{\wedge} 3 \text { cells } / \mathrm{mL} \\
\text {-no mortality in controls } \\
\text {-mussel mortality observation from } 4 * 10^{\wedge} 3 \text { cells } / \mathrm{mL} \\
\text { ( } 24 \mathrm{H} \text { and } 48 \mathrm{H} \text { ) } \\
\text { - critical concentrations: } 6.3^{*} 10^{\wedge} 3 \text { cells } / \mathrm{mL} \text { at } 24 \mathrm{H} \\
\text { and } 3.5^{*} 10^{\wedge} 3 \text { cells } / \mathrm{mL} \text { at } 48 \mathrm{H} \\
=>\text { the toxic algae } \text { Karlodinium armiger is associated } \\
\text { with mussel mortality at concentrations greater } \\
\text { than } 4^{*} 10^{\wedge} 3 \text { cells } / \mathrm{mL} \text {. The authors hypothesize that } \\
\text { the direct contact of toxins with mussels is } \\
\text { deleterious. }\end{array}$ \\
\hline
\end{tabular}

\section{List of references}

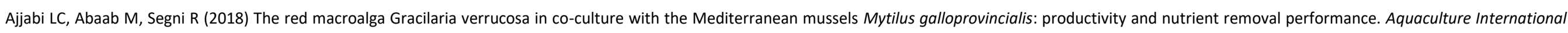
26: 253-266.

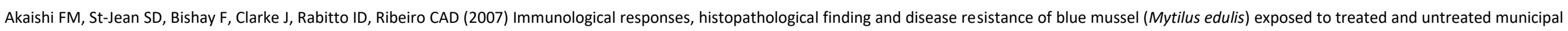
wastewater. Aquatic Toxicology 82: 1-14.

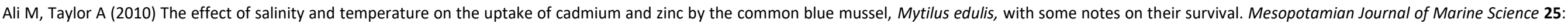
11-30.

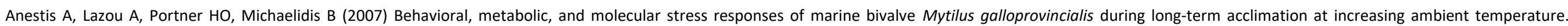
American Journal of Physiology-Regulatory Integrative and Comparative Physiology 293: R911-R921.

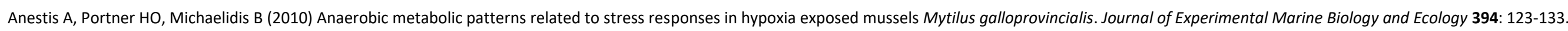
Altieri AH, Witman JD (2006) Local extinction of a foundation species in a hypoxic estuary: integrating individuals to ecosystem. Ecology 87: 717-730.

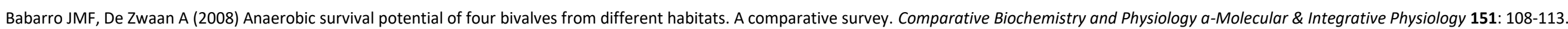
Barrento S, Powell A (2016) The effect of transportation and re-watering strategies on the survival, physiology and batch weight of the blue mussel, Mytilus edulis. Aquaculture 450: 194-198.

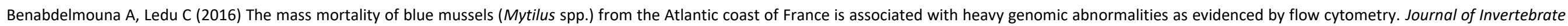
Pathology 138: 30-38.

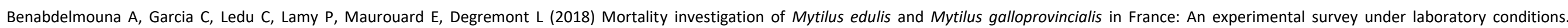
Aquaculture 495: 831-841.

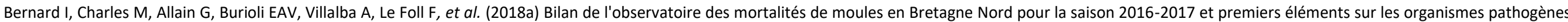
présents. Rapport technique CRC Bretagne Nord, pp. 26. 


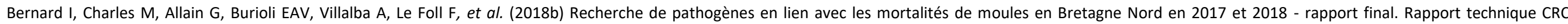
Bretagne Nord, pp. 26

Bertolini C, Montgomery WI, O'Connor NE (2018) Habitat with small inter-structural spaces promotes mussel survival and reef generation. Marine Biology 165.

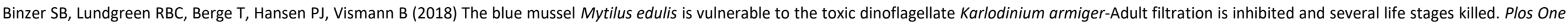
13.

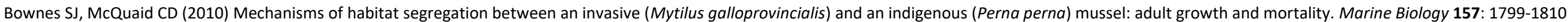

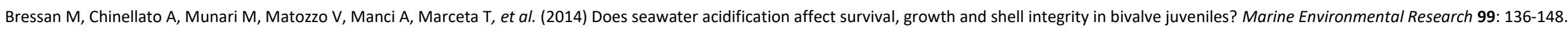

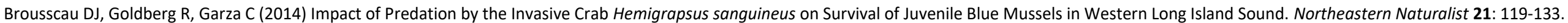

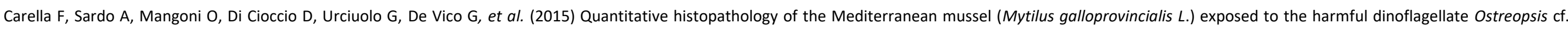
ovata. Journal of Invertebrate Pathology 127: 130-140

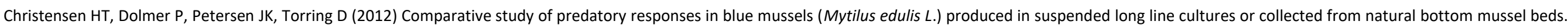
Helgoland Marine Research 66: 1-9.

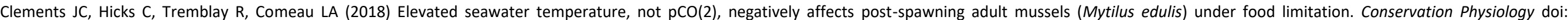
10.1093/conphys/cox078.

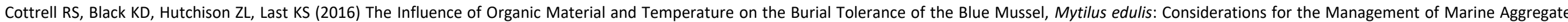
Dredging. Plos One doi: 10.1371/journal.pone.0147534.

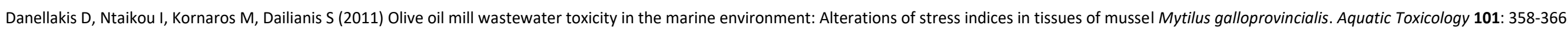

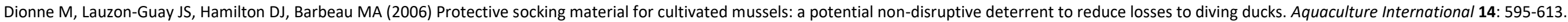

Dowd WW, Somero GN (2013) Behavior and survival of Mytilus congeners following episodes of elevated body temperature in air and seawater. Journal of Experimental Biology 216: 502-514.

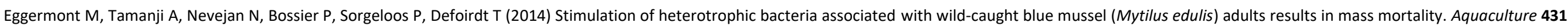
136-138.

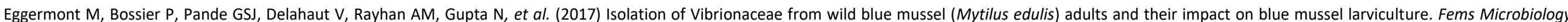
Ecology 93.

Fuentes J, Reyero I, Zapata C, Alvarez G (1992) Influence of Stock and Culture Site on Growth-Rate and Mortality of Mussels (Mytilus galloprovincialis Lmk) in Galicia, Spain. Aquaculture 105: 131-142.

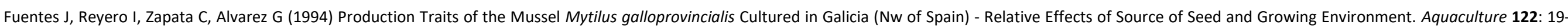
31.

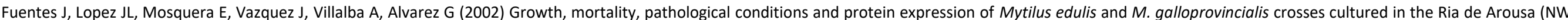
of Spain). Aquaculture 213: 233-251.

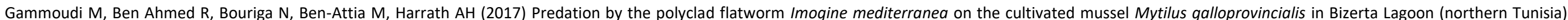
Aquaculture Research 48: 1608-1617.

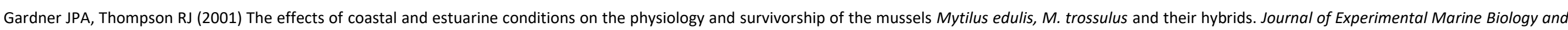
Ecology 265: 119-140.

Gardner JPA (2013) Bottom-up control of temperate rocky intertidal community structure: evidence from a transplant experiment. Marine Ecology Progress Series 491: 137-151.

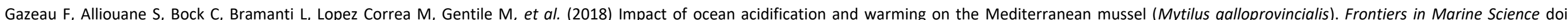
10.3389/fmars.2014.00062.

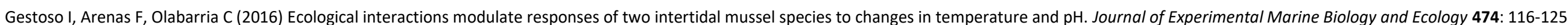
Glize P, Brouard L, Gérard S, Meneur C (2017) Suivi de la mortalité de populations de moules en Pays de Loire : Programme TESCOR. SMIDAP \& CRC Pays de la Loire, pp. 25.

Glize P, Gourmelen G (2018) Suivi de la mortalité de populations de moules en Pays de Loire : Programme TESCOR 2. SMIDAP \& CRC Pays de la Loire, pp. 33.

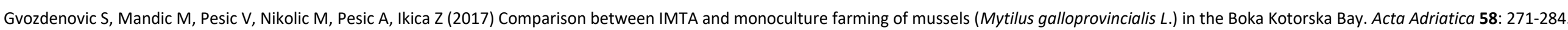

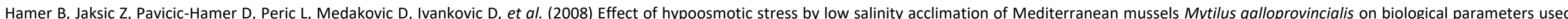
for pollution assessment. Aquatic Toxicology 89: 137-151. 


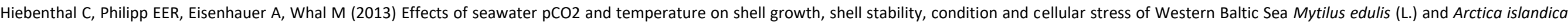
(L.). Marine Biology 160: 2073-2087.

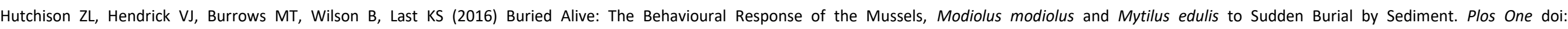
10.1371/journal.pone.0151471.

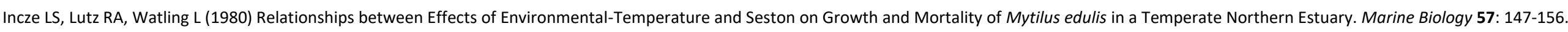
Jones SJ, Mieszkowska N, Wethey DS (2009) Linking Thermal Tolerances and Biogeography: Mytilus edulis (L.) at its Southern Limit on the East Coast of the United States. Biological Bulletin 217: 73-85.

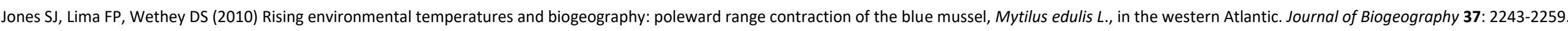
Karayucel S, Karayucel I (2000) The effect of environmental factors, depth and position on the growth and mortality of raft-cultured blue mussels (Mytilus edulis L.). Aquaculture Research 31: 893-899.

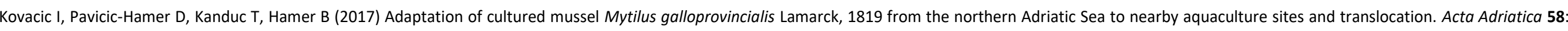
285-296.

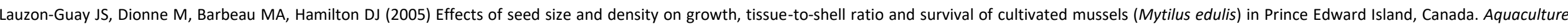
250: 652-665.

LeBlanc N, Tremblay R, Davidson J, Landry T, McNiven M (2008) The effect of selection treatments on Mytilus edulis, modifications of genetic and physiological characteristics. Marine Biology 153: 1141-1152.

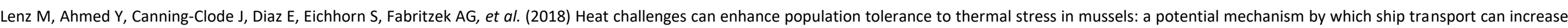
species invasiveness. Biological Invasions 20: 3107-3122.

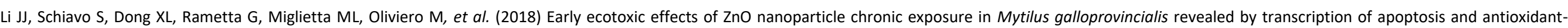
related genes. Ecotoxicology 27: 369-384.

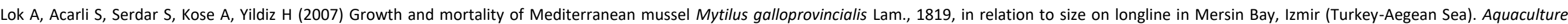
Research 38: 819-826.

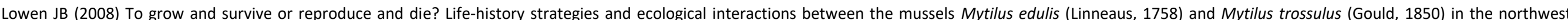
Atlantic. Dissertation Abstracts International 71: 152.

Mallet AL, Carver CEA, Coffen SS, Freeman KR (1987) Mortality Variations in Natural-Populations of the Blue Mussel, Mytilus edulis. Canadian Journal of Fisheries and Aquatic Sciences 44: 1589-1594.

Mallet AL, Carver CEA, Freeman KR (1990) Summer Mortality of the Blue Mussel in Eastern Canada - Spatial, Temporal, Stock and Age Variation. Marine Ecology Progress Series 67: 35-41.

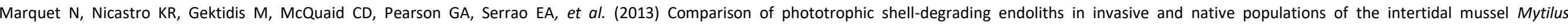
galloprovincialis. Biological Invasions 15: 1253-1272.

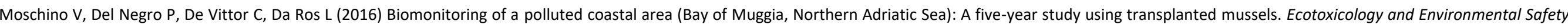
128: 1-10.

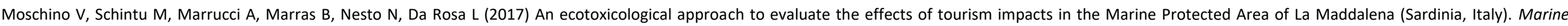
Pollution Bulletin 122: 306-315.

Myrand B, Gaudreault J (1995) Summer mortality of blue mussels (Mytilus edulis Linneaus, 1758) in the Magdalen Islands (southern Gulf of St Lawrence, Canada). Journal of Shellfish Research 14: 395-404.

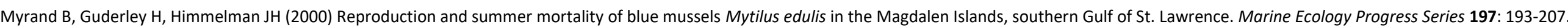

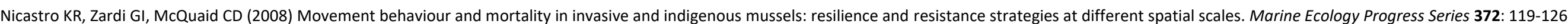

Peden R, Rocher B, Chan P, Vaudry D, Poret A, Olivier S, et al. (2018) Highly polluted life history and acute heat stress, a hazardous mix for blue mussels. Marine Pollution Bulletin 135: 594-606.

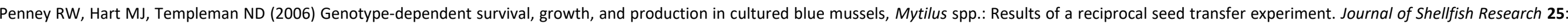
515-525.

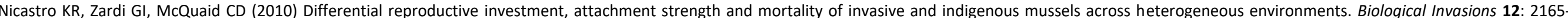
2177.

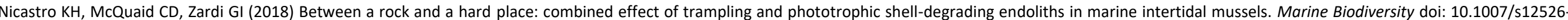
018-0924-3.

O'Connor NE (2010) Shore exposure affects mussel population structure and mediates the effect of epibiotic algae on mussel survival in SW Ireland. Estuarine Coastal and Shelf Science 87: 83-91.

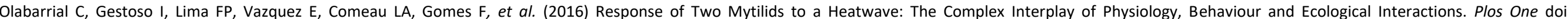
10.1371/journal.pone.0164330. 


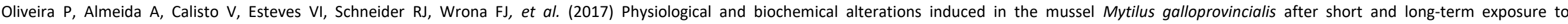
carbamazepine. Water Research 117: 102-114.

Paetzold SC, Davidson J (2011) Aquaculture fouling: Efficacy of potassium monopersulphonate triple salt based disinfectant (Virkon(R) Aquatic) against Ciona intestinalis. Biofouling 27: 655-665.

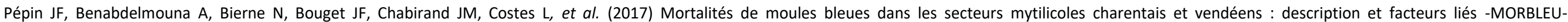
R.INT.RBE/SG2M-LGPMM. https://archimer.ifremer.fr/doc/00391/50288/.

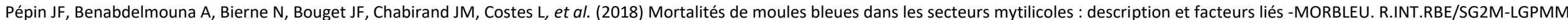

Petraitis PS (1998) Timing of mussel mortality and predator activity in sheltered bays of the Gulf of Maine, USA. Journal of Experimental Marine Biology and Ecology 231: 47-62.

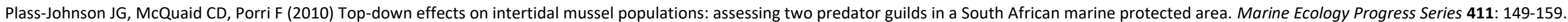

Ramon M, Fernandez M, Galimany E (2007) Development of mussel (Mytilus galloprovincialis) seed from two different origins in a semi-enclosed Mediterranean Bay (NE Spain). Aquaculture 264: 148-159.

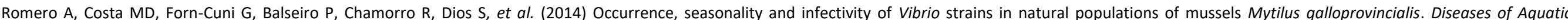
Organisms 108: 149-163.

Rosen G, Lotufo GR (2007) Toxicity of explosive compounds to the marine mussel, Mytilus galloprovincialis, in aqueous exposures. Ecotoxicology and Environmental Safety 68: 228-236.

Schneider KR (2008) Heat Stress in the Intertidal: Comparing Survival and Growth of an Invasive and Native Mussel Under a Variety of Thermal Conditions. Biological Bulletin 215: 253-264.

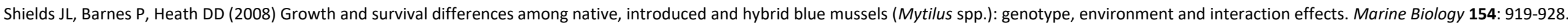

SMIDAP (2016) Suivi du captage et de la mortalité mytilicoles - CAPEMOULES 1. SMIDAP \& CRC Pays de la Loire.

Stevens AM, Gobler CJ (2018) Interactive effects of acidification, hypoxia, and thermal stress on growth, respiration, and survival of four North Atlantic bivalves. Marine Ecology Progress Series 604: 143-161.

Stirling HP, Okumus I (1994) Growth, Mortality and Shell Morphology of Cultivated Mussel (Mytilus edulis) Stocks Cross Planted between 2 Scottish Sea Lochs. Marine Biology 119: 115-123.

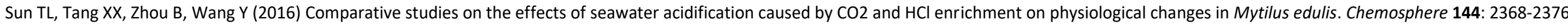

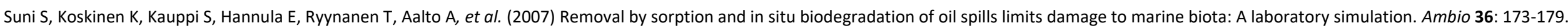

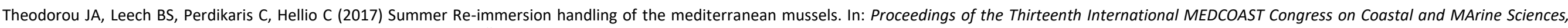
Engeneering, Management and Conservation - MEDCOAST 2017 (ed Öshan E), Mellieha, Malta, pp. 363-368.

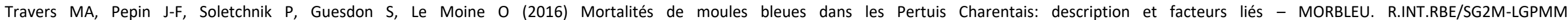
https://archimer.ifremer.fr/doc/00324/43539/.

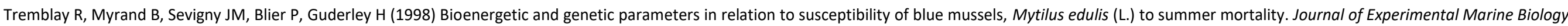
and Ecology 221: 27-58.

Tsarpali V, Dailianis S (2012) Investigation of landfill leachate toxic potency: An integrated approach with the use of stress indices in tissues of mussels. Aquatic Toxicology 124: 58-65.

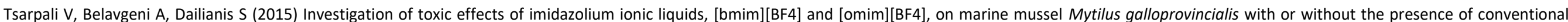
solvents, such as acetone. Aquatic Toxicology 164: 72-80.

Tsuchiya M (1983) Mass Mortality in a Population of the Mussel Mytilus edulis-L Caused by High-Temperature on Rocky Shores. Journal of Experimental Marine Biology and Ecology 66: 101-111.

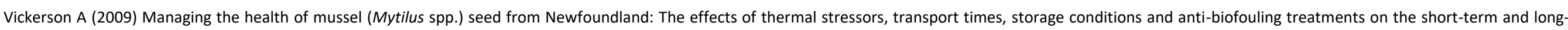
term performance of mussel seed. Masters Abstracts International 48: 114.

Wang J, Ren RM, Yao CL (2018) Oxidative stress responses of Mytilus galloprovincialis to acute cold and heat during air exposure. Journal of Molluscan Studies 84: 285-292.

Waser AM, Splinter W, van der Meer J (2015) Indirect effects of invasive species affecting the population structure of an ecosystem engineer. Ecosphere doi: 10.1890/Es14-00437.1.

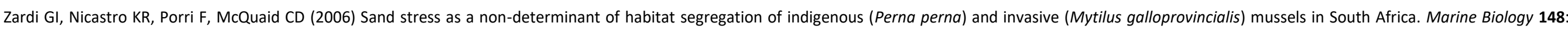
1031-1038.

Zardi GI, Nicastro KR, McQuaid CD, Erlandsson J (2008) Sand and wave induced mortality in invasive (Mytilus galloprovincialis) and indigenous (Perna perna) mussels. Marine Biology 153: 853-858.

Zardi GI, Nicastro KR, McQuaid CD, Ng TPT, Lathlean J, Seuront L (2016) Enemies with benefits: parasitic endoliths protect mussels against heat stress. Scientific Reports doi: $10.1038 /$ Srep31413. 
Appendix IV. Graphical solution of the MCA on the first and second factorial axis, which explained respectively $15.5 \%$ and $12.5 \%$ of the total inertia of the 14 variables, for descriptive characteristics of 114 studies related to risk factors of mussel mortality. Each variable is plotted on the graph according to the coordinates on factorial axis 1 (horizontal) and 2 (vertical).

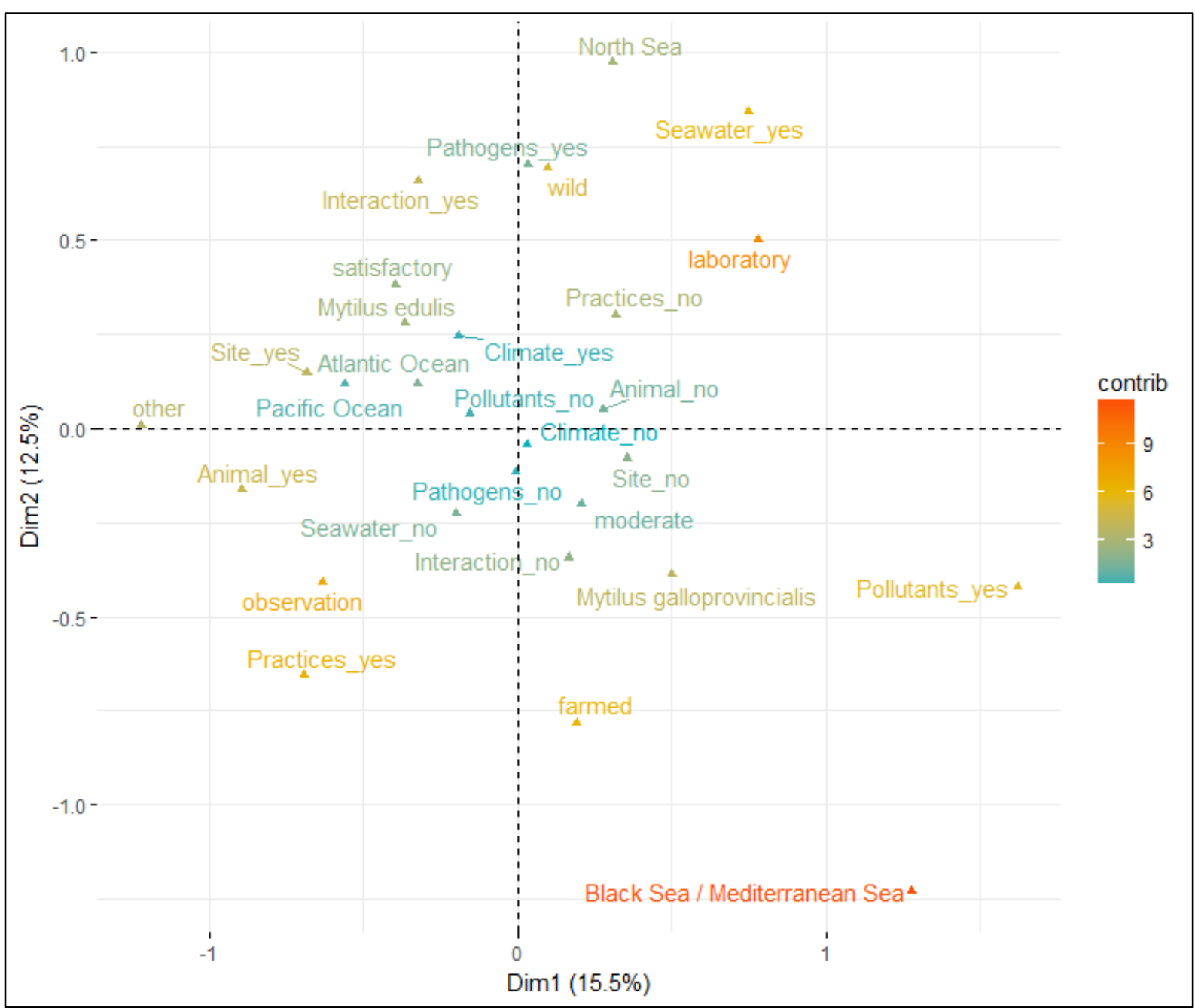

